\title{
A 1200-YEAR RECORD OF FOREST FIRE HISTORY FROM MACROSCOPIC CHARCOAL PRESERVED IN LAKE SEDIMENT, SOUTH-CENTRAL YUKON TERRITORY
}

by

RICHARD V.O. MARCANTONIO, B.A.

\author{
A Thesis \\ Submitted to the Faculty of Graduate Studies \\ in Partial Fulfillment of the Requirements \\ for the Degree \\ Master of Science
}

Carleton University

Ottawa, Ontario, Canada

(C) Copyright by Richard V.O. Marcantonio, January, 2007 


$\begin{array}{ll}\begin{array}{l}\text { Library and } \\ \text { Archives Canada }\end{array} & \begin{array}{l}\text { Bibliothèque et } \\ \text { Archives Canada }\end{array} \\ \begin{array}{l}\text { Published Heritage } \\ \text { Branch }\end{array} & \begin{array}{l}\text { Direction du } \\ \text { Patrimoine de l'édition }\end{array} \\ \begin{array}{l}\text { 395 Wellington Street } \\ \text { Ottawa ON K1A ON4 } \\ \text { Canada }\end{array} & \begin{array}{l}\text { 395, rue Wellington } \\ \text { Ottawa ON K1A ON4 } \\ \text { Canada }\end{array}\end{array}$

Your file Votre référence ISBN: 978-0-494-27022-6

Our file Notre référence

ISBN: 978-0-494-27022-6

NOTICE:

The author has granted a nonexclusive license allowing Library and Archives Canada to reproduce, publish, archive, preserve, conserve, communicate to the public by telecommunication or on the Internet, loan, distribute and sell theses worldwide, for commercial or noncommercial purposes, in microform, paper, electronic and/or any other formats.

The author retains copyright ownership and moral rights in this thesis. Neither the thesis nor substantial extracts from it may be printed or otherwise reproduced without the author's permission.
AVIS:

L'auteur a accordé une licence non exclusive permettant à la Bibliothèque et Archives Canada de reproduire, publier, archiver, sauvegarder, conserver, transmettre au public par télécommunication ou par l'Internet, prêter, distribuer et vendre des thèses partout dans le monde, à des fins commerciales ou autres, sur support microforme, papier, électronique et/ou autres formats.

L'auteur conserve la propriété du droit d'auteur et des droits moraux qui protège cette thèse. $\mathrm{Ni}$ la thèse ni des extraits substantiels de celle-ci ne doivent être imprimés ou autrement reproduits sans son autorisation.
In compliance with the Canadian

Privacy Act some supporting forms may have been removed from this thesis.

While these forms may be included in the document page count, their removal does not represent any loss of content from the thesis.
Conformément à la loi canadienne sur la protection de la vie privée, quelques formulaires secondaires ont été enlevés de cette thèse.

Bien que ces formulaires aient inclus dans la pagination, il n'y aura aucun contenu manquant. 


\begin{abstract}
High resolution analysis of macroscopic charcoal (CHAR) in a sediment core from Burnt Bowl Lake and stand-age information from tree rings were used to develop a fire history reconstruction spanning the last 1200 years in south-central Yukon Territory. Loss-on-ignition (LOI) and magnetic susceptibility were also examined to detect changes in allochthonous sediment inputs associated with past fire events. The CHAR record distinguished 20 fire events and indicates that fire frequency increased from ca. 800 to 1260 A.D., stabilized between ca. 1260 and 1600 A.D. and continued to increase from ca. 1600 A.D. to present. Periods of increasing fire frequency correspond to periods of low precipitation, associated with an intensification of the Aleutian Low pressure system, and increased temperatures during the Medieval Warm Period and following the Little Ice Age (LIA) suggesting that fire frequency in this region is controlled by climate. PostLIA fire frequencies also reflect the influence of anthropogenic ignitions.
\end{abstract}




\section{ACKNOWLEDGMENTS}

I would like to take this opportunity to extend my deepest gratitude to all those who have supported and encouraged me throughout my graduate career. First and foremost, I would like to thank my supervisor Dr. Michael Pisaric. Your guidance, encouragement, support and patience are greatly appreciated. You introduced me to new ideas and allowed me the opportunity to experience Canada's northern regions, a world to which I am inextricably tied and that I likely never would have experienced without you. You are more than a professor, you are a friend.

I would also like to thank the field crew; Don Youngblut, Greg King, Trevor Porter and Kristin Pisaric who helped collect all the field data required for this study. We shared a lot of laughs, interesting conversations and experiences together but I hope none of you ever have to go back to Rancheria. I would especially like to thank Greg who also helped with the lab work. Your diligence and relentless cross-dating of the tree ring samples is greatly appreciated. I would probably still be at the microscope without you. You have become like a little brother to me and in you I have made a friend that will not be soon forgotten. Special thanks are also given to Tara Fischer and Jessica Dorzinsky who also helped with the cross-dating after Greg had decided he had enough. Your enthusiasm and interest in this research was as a source of encouragement and motivation for me that goes far beyond words. I would also like to thank all the members of the Carleton University Paleoecology Lab whose advice and willingness to exchange ideas is greatly appreciated. I wish you all the best in your future endeavours. Thanks to Dr. Jill Johnstone for sharing your knowledge of the Fox Lake region with me and for sharing your home and resources with me and the field crew while in Yukon. Your hospitality is 
greatly appreciated. I would like to extend my appreciation to David Milne of the Yukon Wildland Fire Management Branch for your patience and for sharing your knowledge of the fire history of the Fox Lake region.

I would like to extend my gratitude to Carleton University's Northern Chair, Dr. Christopher Burn, for sharing his knowledge, advice and encouragement and for providing financial support which made this study possible.

On a more personal note, I wish to thank my parents Nicole and Tony and my sister Daniela. Without them I would not be who and what I am today. Your support, generosity and encouragement have allowed me to be successful in both my daily life and academic career. To Carolyn Pharand, who offered me unconditional support and a shoulder to lean on whenever I was in need. You are always in my mind and forever in my heart. I would also like to thank Mrs. Arlene Pharand for proof reading the manuscript and for her encouragement throughout my graduate career.

Financial support for this project was provided by three Northern Scientific Training Program (NSTP) grants to Richard Marcantonio and an NSERC Discovery Grant to Dr. Michael Pisaric. Permission to carry out fieldwork was granted by the Yukon Government Tourism and Culture Department under Yukon Explorers Licence numbers 04-12S\&E, 05-18S\&E and 06-08S\&E. 


\section{TABLE OF CONTENTS}

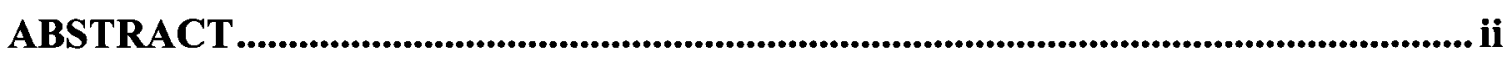

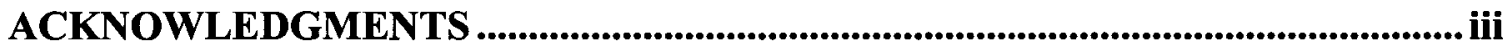

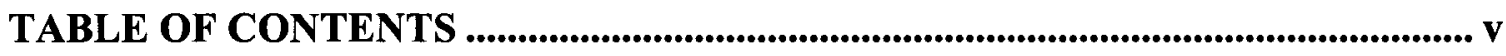

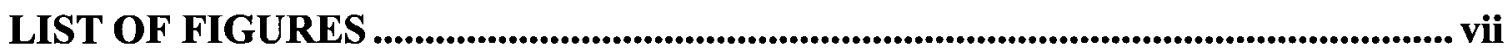

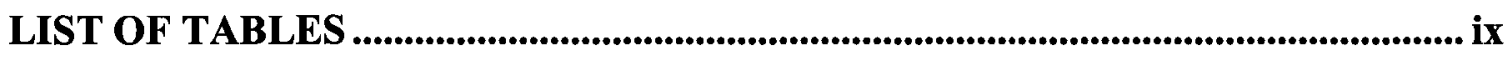

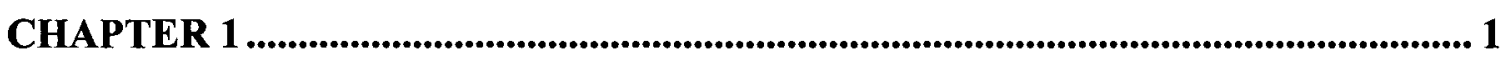

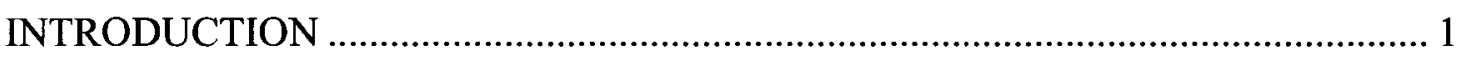

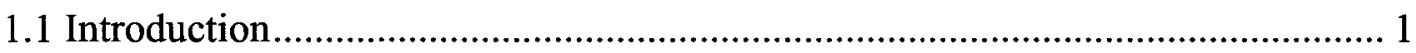

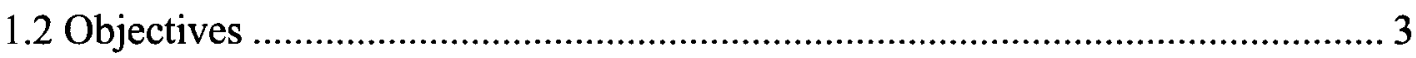

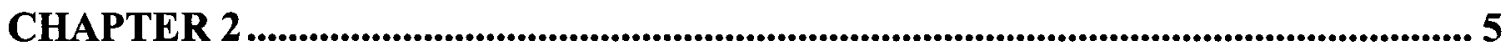

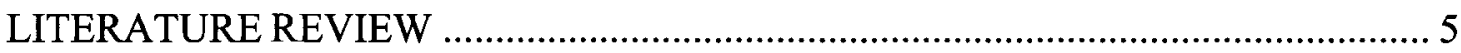

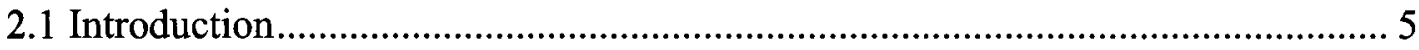

2.2 Dendrochronology and Fire History Reconstruction ................................... 5

2.3 Fire History from Lake Sediments................................................................ 6

2.3.1 Charcoal Production, Dispersal and Deposition .................................... 7

2.3.2 Charcoal Analysis and Fire ................................................................. 8

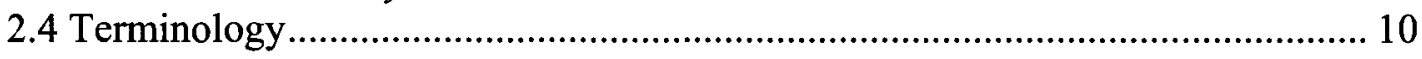

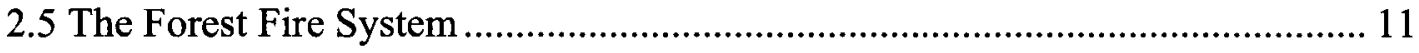

2.5.1 The Role of Topography in Fire Behaviour.......................................... 11

2.5.2 Weather and Fuels as Drivers of Forest Fire ......................................... 13

2.5.3 Climate Change and Forest Fires in Western North America ................... 15

2.6 Forest Fire in Yukon Territory................................................................. 17

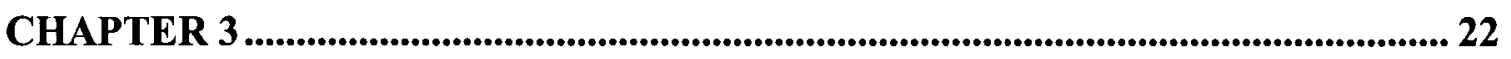

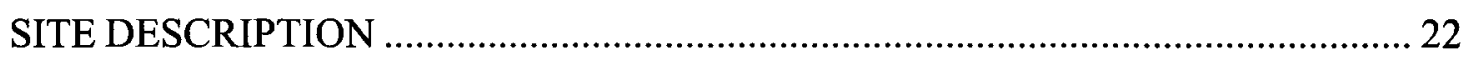

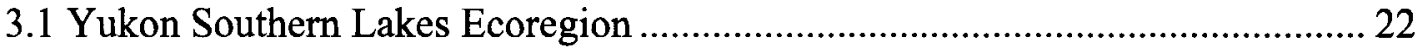

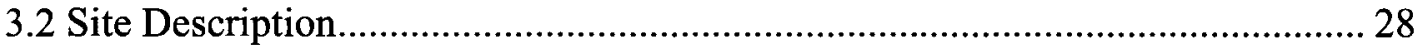

3.2.1. Burnt Bowl Lake ............................................................................ 28

3.2.2. Burnt Bowl Anchor ........................................................................ 31

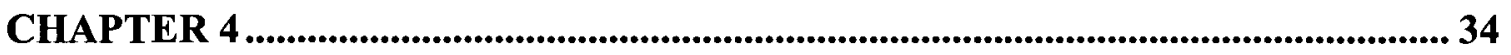

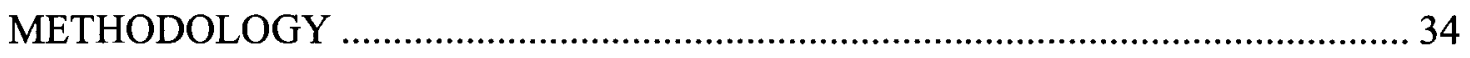

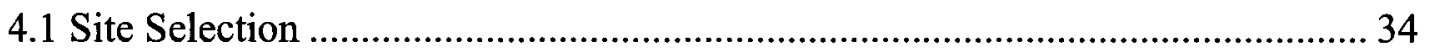

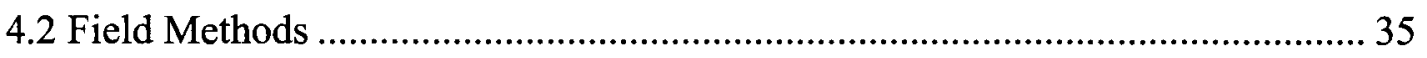

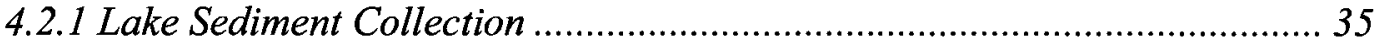

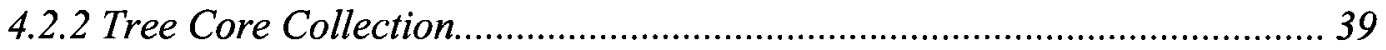

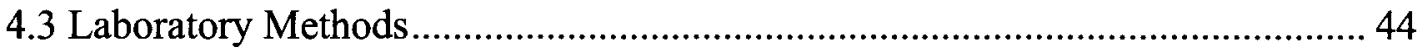

4.3.1 Tree Ring Sample Preparation and Analysis....................................... 44

4.3.2 Stand-Age Structure Analysis ............................................................. 45 


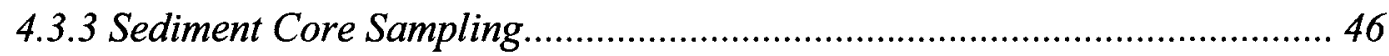

4.3.4 Age-Depth Model ................................................................................ 46

4.3.5 Loss-On-Ignition, Magnetic Susceptibility and Macroscopic Charcoal Analysis ............................................................................................... 47

4.3.6 CHAR Analysis and Identification of Charcoal Peaks ............................. 48

4.4 Investigation of the Controls on the Fire Regime .............................................. 51

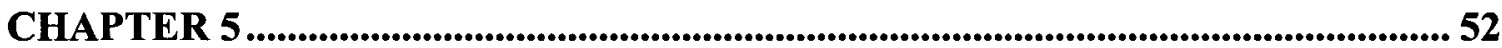

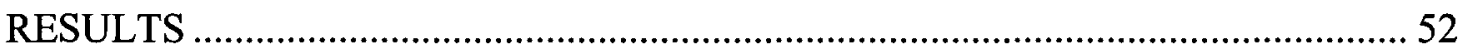

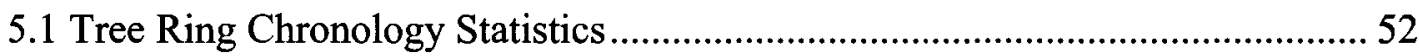

5.2 Stand-Age Structure Analysis.....................................................................52

5.3 Sediment Core Chronology..............................................................................5

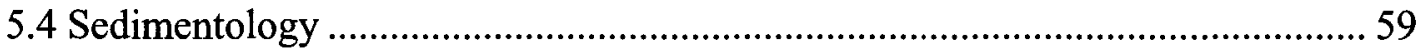

5.5 Sediment Properties ......................................................................................... 62

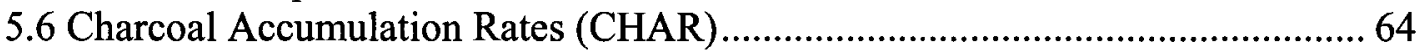

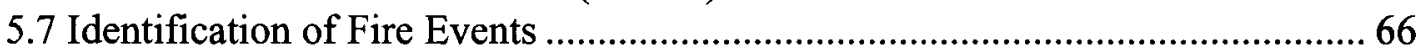

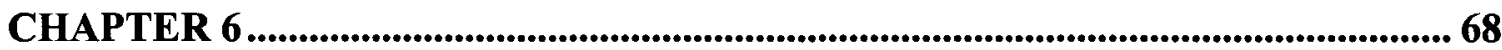

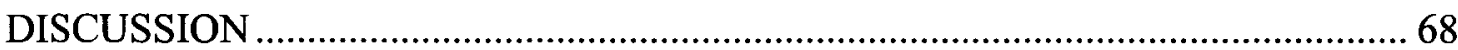

6.1 Macroscopic Charcoal as an Indicator of Forest Fire ........................................6 68

6.2 Fire History Record of South Central-Yukon Territory ....................................... 71

6.3 Vegetation, Climate and Fire in South-Central Yukon Territory ......................... 73

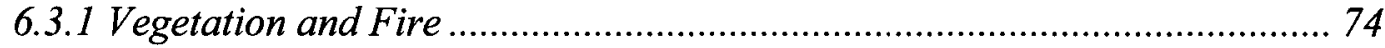

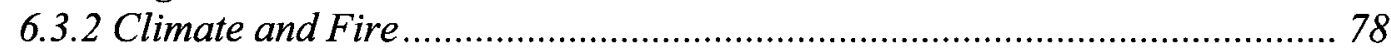

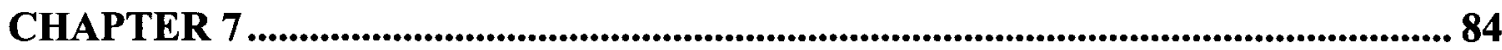

CONCLUSION AND FUTURE CONSIDERATIONS ………................................... 84

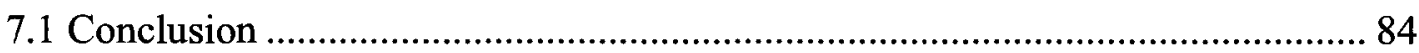

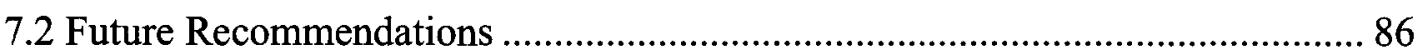

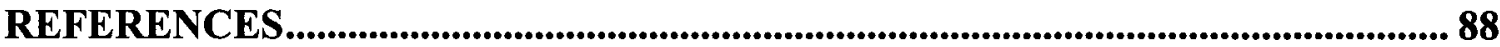




\section{LIST OF FIGURES}

Figure 2.1: Location of forest fires and area burned from 1950-2004 in Yukon Territory.

Figure 3.1: Ecozones and ecoregions of Yukon Territory ...................................... 23

Figure 3.2: Isopleths of the percent frequency of Pacific air occurrence across Canada in July

Figure 3.3: a) Topographic map showing the location of the study site within the study area; b) photograph of Burnt Bowl Lake showing the steep north slope; and c)

photograph of the Burnt Bowl Anchor tree ring chronology site.

Figure 3.4: Extracts of fire history map showing a) the area burned by the 1998 Fox Lake fire; and b) the area burned by the 1958 Braeburn fire. 30

Figure 3.5: Map showing the ignition points, year and the fire size (ha) at extinguishment near the study area..

Figure 4.1: Burnt Bowl Lake showing sediment coring locations and tree ring sampling quadrants.

Figure 4.2: Photograph showing the collection of the surficial sediment core using a Maxi-Glew corer

Figure 4.3: a) Diagram showing general operation of a Livingston piston corer; and b) photograph showing collection of sediment cores using a Livingston piston corer system.

Figure 4.4: Photographs illustrating a) the collection of a tree core sample using a 14-inch Hagloff increment borer; and $b$ ) the collection of a cross-section from a charred spruce tree using a bow saw at Burnt Bowl Lake.

Figure 5.1: Recruitment frequency histograms for individual quadrants and combined quadrants in the Burnt Bowl watershed.

Figure 5.2: Tree mortality frequency histograms for individual quadrants and combined quadrants in the Burnt Bowl watershed.

Figure 5.3: Burnt Bowl Lake surface sediment ${ }^{210} \mathrm{~Pb}$ ages (BB-05-KB1) from constant mass sedimentation (CF:CS) age model.

Figure 5.4: Age-depth model and profile of the surficial and LC2 sediment cores from Burnt Bowl Lake. 
Figure 5.5: Burnt Bowl Lake sediment properties including a) sediment core profile, b) percent organic content $\left(\mathrm{LOI}_{550}\right)$, c) percent calcium carbonate $\left(\mathrm{LOI}_{950}\right)$, d) magnetic susceptibility, and e) charcoal concentration with know fire events in 1998, 1958 and 1890 indicated by asterisks

Figure 5.6: Plots showing a) log-tranformed charcoal concentrations; and b) logtransformed magnetic suscpetibility.

Figure 5.7: Plots showing a) log-transformed CHAR interpolated to 5-year even age interval and background CHAR level (red line); b) peak events representing fires $(+)$; and c) inferred fire frequency.

Figure 6.1: Photograph showing charred root collar indicating the removal of the organic layer as a result combustion by fire. 70

Figure 6.2: Pollen percentage diagrams from a) Hail Lake; and b) Kettlehole Pond...... 75

Figure 6.3: Photograph of a) lodgepole pine seedling at a site north of Burnt Bowl Lake; and b) several spruce seedlings growing at Burnt Bowl Lake

Figure 6.4: Reconstructed phases of the Aleutian Low pressure system based on $\delta^{18} \mathrm{O}$ from Jellybean Lake, YT

Figure 6.5: Reconstructed surface water temperature anomalies from Farewell Lake, Alaska. 


\section{LIST OF TABLES}

Table 4.1: Inventory of sediment cores collected from Burnt Bowl Lake...................... 38

Table 4.2: Tree core and cross-section inventory. .................................................. 43

Table 5.1: Tree-ring chronology summary statistics calculated by program COFECHA.53

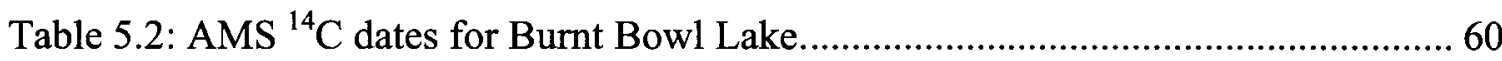




\section{CHAPTER 1 \\ INTRODUCTION}

\subsection{Introduction}

Forest fires are a cornerstone of the natural functioning of boreal ecosystems in

Canada. Although often perceived as a destructive force in nature, wildfires are essential to ensure the continuity and ecological integrity of the boreal forest. The physiognomy of the Canadian boreal forest, past and present, is inexorably tied to the fire regime which is often characterized by large but infrequent, high intensity stand-replacing fires (Heinselman, 1973; Flannigan et al., 2000; Stocks et al., 2003).

During the 1990s, fire consumed on average 2.75 million hectares of forest annually across Canada (Stocks et al., 2003), contributing to a patchwork mosaic of different species and age classes. In comparison, 3.3 million hectares of forest burned across Canada in 2004 (Natural Resources Canada, 2005). During this century, humaninduced changes in the climate system due to an increase in atmospheric greenhouse gas concentrations may alter natural fire regimes through an increase in fire severity, frequency and length of the forest fire season (Stocks et al., 1998). As a result, the average annual area burned by forest fires in Canada is projected to increase by $74-118 \%$ by the end of this century under a $3 \mathrm{x} \mathrm{CO}_{2}$ scenario (Flannigan et al., 2005).

The prospect of climate change is of concern in the Canadian boreal forest as climate is one of the most important factors contributing to fire occurrences (Bessie and Johnson, 1995). In northwestern Canada this is potentially of greater concern as this region of Canada has experienced the greatest warming in recent decades (ACIA, 2004). 
Since the 1950 s mean annual temperatures in northwestern Canada have increased by approximately $2-3^{\circ} \mathrm{C}$, while winters have increased by as much as $4^{\circ} \mathrm{C}$ (Chapman and Walsh, 2003). In contrast, global mean temperatures have increased $\sim 0.6^{\circ} \mathrm{C}$ in the last century (Jones and Briffa, 1992; Hulme and Jones 1994; Folland et al., 2001). Climate models also predict an increase of $\sim 1.8^{\circ} \mathrm{C}$ in global mean temperature (Barthelet et al., 1998; Stouffer and Manabe, 1999; Boer et al., 2000; Meehl et al., 2000; Cubasch et al., 2001) and up to $5^{\circ} \mathrm{C}$ in northern regions over the next century (ACIA, 2004).

Increased fire activity under a climate warming scenario is of concern in Yukon Territory because: 1) increased fire frequency, intensity, severity and length of the fire season could alter the trajectory of forest development towards species better adapted to disturbances by fire, including pioneer species adapted to recently disturbed sites; 2) forests are a major carbon sink and increased fire activity could result in the release of large quantities of carbon into the atmosphere resulting in positive feedbacks to the global climate system; 3) wildfire could affect wildlife populations and migration routes due to the alteration of suitable habitats; 4) the tourism, forest and mining industries would be negatively impacted by more intense and frequent forest fires; and 5) human populations are increasingly occupying the urban-forest interface, increasing the risk of loss of life and property as well as damage to community infrastructure. In order to provide accurate predictions about the future trajectory of forest fire regimes in northwestern Canada, it is imperative that long records of fire occurrences extending beyond the instrumental period of record are developed in order to examine and thus further our understanding of how fire and climate have interacted in the past. 


\subsection{Objectives}

The boreal forest of south-central Yukon Territory provides an excellent opportunity to examine fire-climate relations using paleoecological techniques. Climatic conditions and vegetation composition in this region are conducive to large fire events and thus natural fire regimes are expected to be sensitive to variations in climate. The region is characterized by high summer temperatures, cold winter temperatures and low moisture availability. Using dendrochronology and paleolimnology, the relation between fire and climate can be studied at multiple spatial and temporal scales to provide a record of fire occurrences for the area of interest. As the impacts of climate change are expected to be greatest in the north, this region can serve as an indicator of future conditions.

The objectives of this research are: 1) to examine the potential of using macroscopic charcoal preserved in lake sediment and tree ring growth records to study the occurrence of fire in south-central Yukon Territory beyond the instrumental period of record; and 2) to examine the occurrence of forest fires in south-central Yukon Territory in order to determine how the natural variability of forest fire regimes has changed in response to climate during the Late Holocene. These objectives will be accomplished by developing a reconstruction of fire events within the Fox Lake region of Yukon Territory at both millennial and centennial time scales.

This research will provide a basic framework for studying the interaction between fire and climate at various timescales in northwestern Canada and will be among the first to investigate fire activity using both dendrochronological and lake sediment techniques in this region. The results of this study may also provide important information for forest managers and planners regarding the natural occurrence of fire and its interaction with 
changing climatic conditions. This information may be of importance when considering strategies for managing natural resources such as forests and wildlife; and, planning for future infrastructure such as communities and roadways. 


\section{CHAPTER 2}

\section{LITERATURE REVIEW}

\subsection{Introduction}

The following chapter provides a description of dendrochronology and paleolimnology as tools for developing a reconstruction of past forest fire activity. This is followed by a discussion of the forest fire system focusing on the major components which influence the behaviour of forest fires within the boreal region. A review of forest fire history research in western North America examines the present knowledge-base regarding climate-fire relations during the Holocene period focusing on the western United States, British Columbia, and Alaska. This chapter concludes with an examination of the knowledge-base and previous forest fire studies carried out in Yukon Territory.

\subsection{Dendrochronology and Fire History Reconstruction}

In terms of the study of fire activity, dendrochronology is primarily used to accurately date physical evidence of a fire, most notably fire scars. A fire scar is formed when a fire burning adjacent to a tree raises the temperature of the cambial layer to a lethal level or burns and consumes a portion of the bark, cambium and xylem (McBride, 1983). By assigning an absolute date to the fire-scarred growth ring, the year and in some cases the season, in which the particular fire occurred can be precisely determined. However, in regions where stand-replacing fires are dominant, fire scars are often not present as the majority of the trees are killed by the fire event. 
Stand-age structure analysis is another form of evidence that can be used to determine the occurrence of fire in regions where stand-replacing fires are dominant (Kipfmueller and Baker, 1998). Using stand-age analysis, the date of fire occurrence is obtained by determining the age of trees believed to have been recruited immediately after a fire event. A major difficulty associated with this technique is finding trees that were established in the same or next year after a fire (Johnson and Gutsell, 1994). In many cases, recruitment may not have occurred for several years following a fire consequently providing a fire date several years after the fire occurred. Often, comparison with a good fire record developed from fire scars at a nearby site can suggest an accurate fire date. However, a more cautious approach is to infer that the date of a fire is at least as old as the oldest tree found, but that the actual fire date is not known (Johnson and Gutsell, 1994).

\subsection{Fire History from Lake Sediments}

Fire history reconstructions based on lake sediment records can be derived from three primary data sources: 1) particulate charcoal that provides direct evidence of burning; 2) pollen evidence of fluctuations in vegetation composition linked to disturbance; and 3) lithological evidence of watershed adjustment in response to fire (Whitlock and Larsen, 2001). Fire histories are most commonly developed using sedimentary charcoal as it can provide direct evidence of fire activity, is relatively easy to identify and inexpensive to carry out. 


\subsubsection{Charcoal Production, Dispersal and Deposition}

The ability to reconstruct past fire events using sedimentary charcoal is predicated on the understanding of the processes that control charcoal production, dispersal, deposition and accumulation in lakes following fire events (Gardner and Whitlock, 2001). Charcoal particles are produced when organic materials are not completely combusted during a fire event (Whitlock and Larsen, 2001). The individual characteristics of a fire such as intensity, severity and size will affect the production and dispersal of particulate charcoal (Whitlock and Larsen, 2001). Primary charcoal refers to particulate charcoal introduced to a lake during or shortly after a fire event. Secondary charcoal is introduced during non-fire years as a result of surface runoff and the redeposition of lake sediments. Charcoal can be carried to great heights in convective heat plumes and dispersed over great distances by wind (Pisaric, 2002) and thus the source of charcoal within a sediment sequence may be from distant regional fires, extra-local fires occurring nearby but not within the watershed of a lake, or local fires which occur within the watershed of a particular lake (Whitlock and Larsen, 2001). Studies from experimental and opportunistic fires show that macroscopic charcoal particles $(>150 \mu \mathrm{m})$ are deposited short distances away from the burn edge and represent local to extra-local fire events (Clark and Royale, 1996; Clark et al., 1998; Gardner and Whitlock, 2001; Lynch et al., 2004a). In contrast, microscopic particles $(<150 \mu \mathrm{m})$ offer information concerning regional fires in the past, but their ability to identify specific fire events has generally been less certain (Millspaugh and Whitlock 1995). 
Several assumptions underlie the use of sedimentary charcoal as an indicator of fire events which have occurred in the past. According to Whitlock and Millspaugh (1996), these assumptions include:

1) Peaks in charcoal abundance above a determined background amount are evidence of a fire event in the past.

2) Most sedimentary charcoal is from primary fallout during or shortly after a fire.

3) Large particles $(>150 \mu \mathrm{m})$ are not readily dispersed and are thus evidence of a local fire event.

4) Smaller lakes have a smaller collection area and thus provide a better record of local fires than do large lakes.

These assumptions represent guidelines and the relation between various components of the fire system that must be considered when using sedimentary charcoal to reconstruct past fire events.

\subsubsection{Charcoal Analysis and Fire}

Charcoal analysis quantifies the accumulation of charcoal particles in lake sediments deposited during and following a fire event. This is accomplished by calculating a charcoal accumulation rate (CHAR) composed of two components: 1) a low frequency or slowly varying background component; and 2) a higher frequency or more rapidly varying component described as a charcoal peak (Long et al., 1998). The background component consists of several subcomponents representing the input of secondary charcoal in non-fire years that reflect rates of charcoal production, charcoal sequestered in the watershed and littoral zone of the lake and a regional component that represents the primary charcoal contribution of fires within the region but not within the 
watershed (Long et al., 1998). The peak component represents the contribution of primary charcoal deposited during or shortly after a single fire event in the watershed and sometimes adjacent watersheds (Long et al., 1998). The peak component is also assumed to consist of subcomponents including: 1) a major subcomponent that represents the input from a particular fire; and 2) a minor "noise" subcomponent that includes both analytical error and natural random variation in CHAR (Long et al., 1998). Within lakes, stratigraphic levels with peaks in CHAR exceeding a quantitatively defined threshold value are inferred to be evidence of past fire events. The threshold value represents the background component and is arrived at through statistical analysis of the CHAR record. These stratigraphic levels containing charcoal peaks can be dated using radiometric dating techniques and calibrated using dendrochronological and historical records in order to provide an approximation of when the fire events occurred. Depending on the temporal resolution of the sedimentary record and sampling strategy, a fire event identified using this technique could represent a single fire or a sequence of fires clustered closely together in time.

In addition to macroscopic charcoal analysis, magnetic susceptibility can be used as an indicator of changes in mineral content in lake sediment records (Sandgren and Snowball, 2001). This technique allows fire events to be detected magnetically due to the process of magnetic "enhancement" that occurs in topsoil during a forest fire (Rummery et al., 1979; Gedye et al., 2000). During a fire, weakly magnetic iron oxides and hydroxides are thermally transformed to ferrimagnetic magnetite or maghemite in the presence of burning organic matter (Leborgne, 1960; Oldfield, 1981; Kletetschka and Banerjee, 1995; Geydes et al., 2000). This transformation can occur at temperatures as 
low as $100^{\circ} \mathrm{C}$ to $200^{\circ} \mathrm{C}$, but most enhancement occurs at temperatures in excess of $500^{\circ} \mathrm{C}$ (Geydes et al., 2000). These highly magnetic sediments are then transported to the lake basin causing an increase in the magnetic susceptibility profile.

\subsection{Terminology}

Before continuing the discussion of forest fires, it is important that some of the terms used to describe the components of the forest fire regime are defined. First, fire frequency refers to the average number of fires that occur at a specified point per unit time (Hallett and Walker, 2000). Until recently, the fire cycle had been defined as the period of time required to completely burn an area equal in size to the study area (Johnson and Gutsell, 1994). However, Reed (2006) demonstrated that by definition, the fire cycle value is a random variable. Reed (2006) suggests that the notion of fire cycle no longer be used or if it is that it be defined as identical to the local fire interval which is a measure of the average number of years between fire events at a specified point (Hallett and Walker, 2000). In relation to these components, fire intensity is a measure of the amount of energy released during a particular fire event while fire severity represents the amount of fuel that is consumed during an event (Flannigan et al., 2000). Fire type refers to crown, surface and ground fires which are controlled by fire intensity, weather and fuel characteristics such as structure and moisture (Stocks et al., 2003). Seasonality simple refers to the time of year in which the fire occurs (Stocks et al., 2003). The fire regime comprises fire frequency, intensity, severity, size, seasonality and type (Stocks et al., 2003). 


\subsection{The Forest Fire System}

The occurrence of a forest fire depends on the complex interaction between several physiological, biological and climatic factors acting on various spatial and temporal scales to determine the forest fire regime. The fire regime at any given location is defined by the prevalent weather, fuel, topographic and long-term climatic patterns (Bessie and Johnson, 1995; Larsen, 1997; Flannigan et al., 2000; Hallett and Walker, 2000; Hély et al., 2001; Lynch et al., 2004b). However, there is much disagreement as to which of these factors are most important in determining the forest fire regime of a particular location. It would appear that the factors determining forest fire regimes vary both spatially and temporally and therefore, although one factor may be central to the fire regime in one area, it may not exert the same influence at a different site. The following discussion will examine the relative importance of each of these components in regards to their influence in determining the forest fire regime.

\subsubsection{The Role of Topography in Fire Behaviour}

The role of topography in contributing to the occurrence and spread of forest fires can best be observed on relatively fine spatial scales (Heyerdahl et al., 2001; Rollins et al., 2002). Topography can affect fire frequency and fire size both directly and indirectly. Natural fire breaks can act as a barrier to fire thus limiting the spread of a forest fire and confining it to a particular area. For example, waterbodies such as lakes, rivers and wetlands provide a natural fire break and can stop the spread of a fire depending on their extent (Heinselman, 1973; Larsen, 1997). Similarly, features such as natural ridges, large bedrock outcrops and glacial features can also provide barriers and confine a fire to a particular area (Heinselman, 1973; Clark, 1990). In contrast, the alignment of 
topographical features such as valleys, troughs and lakes influence weather patterns by funnelling high winds which can direct fire down a constant pathway (Heinselman, 1973).

Topography can also affect fire indirectly through slope aspect and gradient which influences the amount of incoming solar radiation received at the surface, fuel moisture and vegetation composition. Several studies suggest that fires are more frequent on south and west facing slopes (e.g. Clark, 1990; Heyerdahl et al., 2001; Hallett et al., 2003). At the beginning of the fire season, snowmelt occurs quickly on steep south and west facing slopes and thus fuels dry out quickly and remain dry for a longer period of time (Heyerdahl et al., 2001). Further, slope gradient can influence the vegetation composition resulting in more fire prone species establishing on south and west facing slopes.

Although topography can influence the fire regime on local scales, it may not always be a major factor and may be overridden by other components of the fire system depending on site specific conditions. For example, Johnson and Larsen (1991) found that forest fire activity and spatial patterns in the Kananaskis River watershed did not vary in response to topographical features. Instead, the fire regime in this area is controlled predominately by local weather patterns which override the influence of topography. Therefore, it appears that the effects of topography on fire activity are mainly constrained to small spatial scales and are limited by the interaction with other components of the forest fire system. 


\subsubsection{Weather and Fuels as Drivers of Forest Fire}

Weather and fuels play a central role in determining fire behaviour in the Canadian boreal forest. As a result, researchers have found it difficult to determine the relative importance of these individual components on forest fire. Weather can influence fire behaviour on local to regional spatial scales and can vary over fine temporal scales ranging from hours to months (Lynch et al., 2004b). In contrast, although fuels also influence fire behaviour both locally and regionally, they vary over much longer time scales (Bessie and Johnson, 1995).

Weather can influence the fire environment both prior to and during a fire event. The weather conditions prior to a fire event are important as they can influence fuel moisture. Weather conditions that influence fuel moisture include wind speed, temperature and precipitation (Bessie and Johnson, 1995; Flannigan et al., 2000; Hély et al., 2001). High temperatures and low precipitation associated with persistent highpressure blocking systems dry the fine fuels present in the forest (Johnson and Larsen, 1991; Bessie and Johnson, 1995; Flannigan et al., 2000; Hallett and Walker 2000). Where such conditions occur, fire can be readily ignited either by lightning or due to human activity. Ignition by lightning may occur in association with fast-moving cold fronts or during convective storms which cause atmospheric instability (Johnson and Larsen, 1991). Although fuels are quite dry under high-pressure conditions, the rate of spread will be relatively slow as high-pressure systems are generally associated with low wind speeds. High rates of spread occur during transitions between high and low pressure systems where wind speeds are high and gusty (Johnson and Larsen, 1991). Wind speed can strongly affect heat transfer rates by increasing both radiative heat 
transfer due to tilting of the flame and convective heat transfer (Bessie and Johnson, 1995). Because of both high rates of spread and intensity associated with such conditions, fires are generally oriented by wind direction and speed (Johnson and Larsen, 1991). In such cases where weather conditions are conducive to large fire events, dry fine fuels may play a lesser role in fire behaviour acting only as a burnable medium providing the heat of combustion rather than contributing to fire intensity, spread and burn patterns (Bessie and Johnson, 1995).

There is no doubt that fuels play a central role in determining fire behaviour and frequency. Under moderate weather conditions, fuels may play a larger role than weather as fire spread becomes sensitive to the spatial arrangement of fuels (Miller and Urban, 2000). In forests where fuels are arranged in such a pattern that fires can spread from one area to another, the fuels are said to be connected thereby allowing fires to spread over large areas (Miller and Urban, 2000). Similarly, fuels can also be vertically connected where fuels provide a ladder-like arrangement creating the potential for fire to pass from surface fires to the crowns of trees in the stand (Stephens, 1998). However, under extreme weather conditions where wind speeds are high and gusty, the spatial arrangement becomes less important (Miller and Urban, 2000).

Fire behaviour and frequency are also influenced by the fuel type within the area of interest. It has been suggested that fire behaviour can be influenced by the dominant tree species found within the forest. In the eastern Canadian mixed-wood boreal forest, low fire frequencies and reduced severity may be associated with the presence of deciduous species which are less flammable and thus less prone to burn (Bergeron et al., 2001; Hély et al., 2001). Conversely, highly combustible coniferous species are dominant 
in the western boreal forest and increases the likelihood of larger more intense fires given the appropriate weather conditions (Bessie and Johnson, 1995; Hély et al., 2001; Lynch et al., 2003).

Different weather conditions and fuel characteristics interact with topography to provide a unique fire environment within a particular region. Each specific condition can override the other to produce a fire behaviour that is unique to that particular site. It is important to understand how each of these factors influences the fire regime and to determine how these components interact with each other when examining the fire regime in a particular area.

\subsubsection{Climate Change and Forest Fires in Western North America}

The prospect of increasing temperatures and the recent occurrence of several large fire events in western North America, such as the Yellowstone fires of 1988 and the British Columbia fires of 2003, have sparked an interest in determining the influence of climate on forest fires. The previously discussed components of the fire system influence fire on relatively short temporal and fine spatial scales. In contrast, the climate system has the ability to influence fire regimes over much longer time scales (decadal to millennial) and across larger spatial scales (regional to continental). Further, climate can directly influence fire regimes over long time scales via changing temperatures, precipitation and other climatic variables; or indirectly as a result of changes in vegetation composition as a result of changing climatic conditions. For these reasons, recent studies have focussed on examining how changing climates and associated shifts in vegetation composition have interacted with forest fire regimes over the duration of the Holocene period (e.g. Whitlock, 1993; Long et al., 1998; Hallett and Walker, 2000; 
Hallett et al., 2003; Lynch et al., 2003, 2004b). These studies have mainly focussed on determining how climate change has affected forest fire regimes in the past as well as determining whether recent fires represent a departure from the natural variability experienced throughout the Holocene.

In western Canada and the United States, climate appears to be the major influence on shifting fire regimes over millennial time scales. However, as with weather, topography and fuel composition, the effects vary regionally. Several fire history reconstructions of the Holocene period in the Pacific Northwest of the United States, where summer conditions are dry and most of the precipitation is received in the winter, indicate that the highest fire activity occurred in the early part of the Holocene (11 0007000 yrs B.P. (before present)) and during the Medieval Warm Period when conditions were warmer and possibly drier than today (Whitlock, 1993; Long et al., 1998; Millspaugh et al., 2000; Mohr et al., 2000; Long and Whitlock, 2002). A similar response was also recorded in Kootenay National Park where fires were most frequent between $8200-4000$ yrs B.P. which corresponded to warmer and drier conditions than present and forests were composed of fire prone species (Hallett and Walker, 2000).

In contrast regions of the Northern Rockies of the United States, where most of the annual precipitation is presently received in the summer, experienced their highest fire activity in the last 7000 years (Whitlock et al., 2003). This increase in fire activity is suggested to be associated with the expansion of forest species that are more prone to fire which developed in association with changing climatic conditions (Whitlock et al., 2003). Similarly, fire regimes in Alaska appear to be closely related to shifts in vegetation composition associated with changing climatic conditions, rather than increasing 
temperatures as seen in other portions of western North America. For example Lynch et al. $(2003,2004 \mathrm{~b})$ concluded that fires occurred more frequently under wetter and cooler climatic conditions associated with the expansion of black spruce forests and more frequent ignitions by lightning.

\subsection{Forest Fire in Yukon Territory}

The boreal forest covers approximately 27 million hectares of Yukon Territory and similar to boreal regions across Canada it is often subjected to large stand-replacing fires (Yukon Wildland Fire Management, 2005). The forests of Yukon Territory are a mosaic of age-classes in varying stages of succession resulting from successive forest fires. Historically, fire occurrence patterns trend southeast from Dawson to Ross River (Fig 2.1). The regions of Old Crow, Eagle Plains and the Peel River are also areas where wildfire plays an important role in the functioning of those ecosystems (Yukon Wildland Fire Management, 2005). This spatial pattern of fire occurrence is related to the presence or absence of fire-prone vegetation which is influenced by the elevation of the terrain, glaciation and the physiographic characteristics of these regions.

Generally, lightning strikes account for approximately 55\% of fires in Yukon Territory and tend to result in large areas burned while the remaining $45 \%$ tend to be smaller fires occurring near settlements as a result of human caused ignitions. (Yukon Wildland Fire Management, 2005). During the past 25 years, an average of 140 wildfires burned approximately 120000 hectares of land annually. However, since 1950 the annual area burned exceeded 200000 hectares 12 times demonstrating an intermittent cycle of extreme fire years in the Territory (Yukon Wildland Fire Management, 2005). 


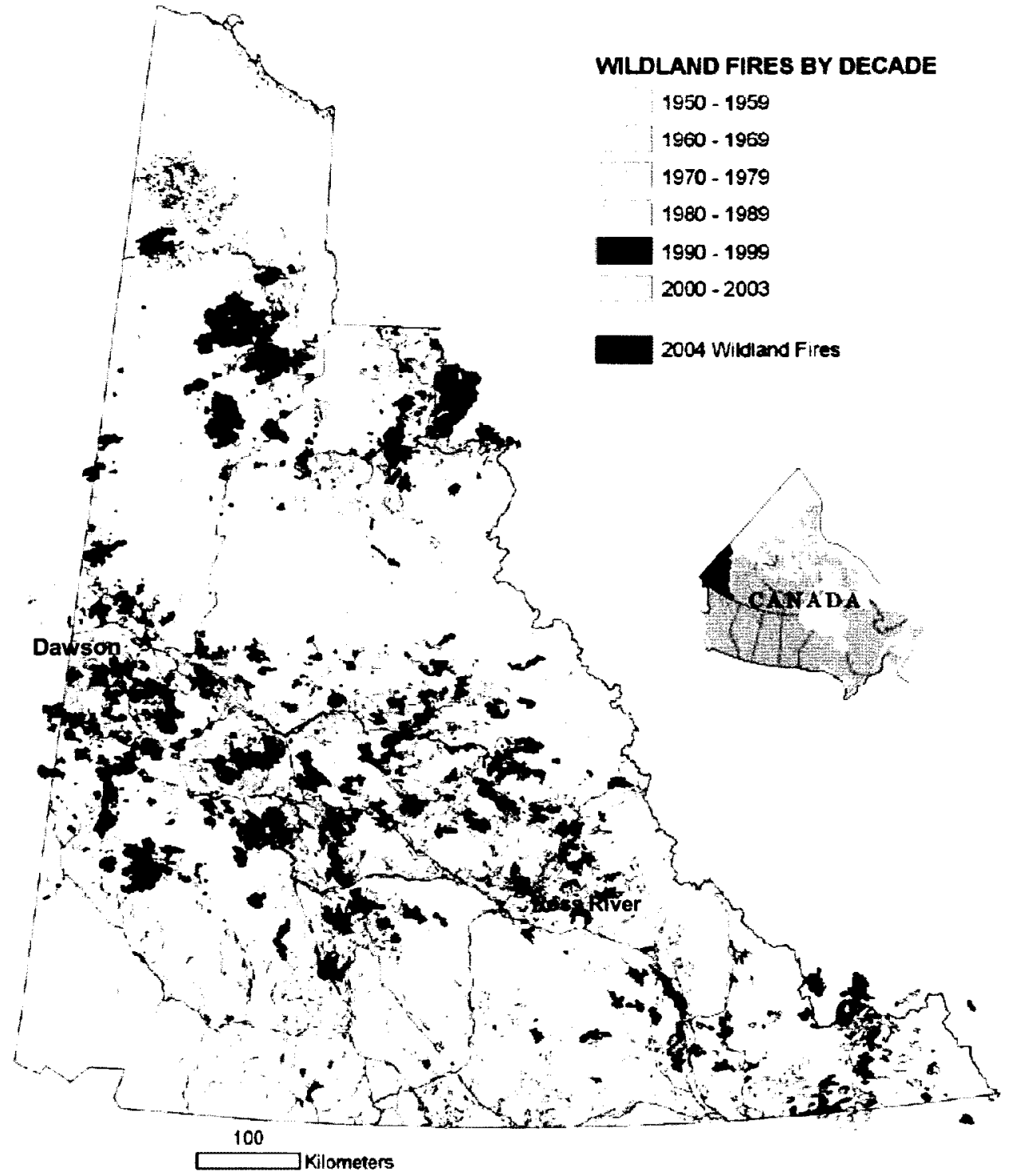

Figure 2.1: Location of forest fires and area burned from 1950-2004 in Yukon Territory (Yukon Wildland Fire Management, 2005). 
The 2004 fire season was the most extreme fire season on record. In comparison to the 120000 hectares burned on average annually in the last 25 years, over 1.82 million hectares of forests were consumed by fire in the 2004 season accounting for $55 \%$ of the forests consumed across Canada (Natural Resources Canada, 2005). By late June 2004, $\sim 120$ fires had been ignited by lightning. New fires continued to ignite in July as a result of high wind speeds, record temperatures and extreme fire behaviour and through August due to a wave of lightning storms. The 2004 fire season came to an end at the beginning of September with 282 forest fires consuming 5.6\% of Yukon's forested regions. (Yukon Wildland Fire Management, 2005).

Within Yukon Territory, little information exists concerning natural fire regimes beyond the historical period of observation. As a result, the characterization and interpretation of natural fire regimes are estimated based on a relatively short period of data collection beginning in 1950 . Consequently, the information available may not represent the natural variability of fire within the Territory as fire intervals in the boreal forest tend to range between $80-400$ years (MacDonald, 2003). The lack of information beyond the historical period of observation may result in erroneous estimates of fire regimes across the Territory making it difficult for resource managers to develop adequate strategies for managing boreal resources subjected to wildfire.

Although little information beyond the historical period of observation exists, there are hints on the landscape of changing climatic conditions and fire regimes in the Yukon. For example, surveys of fire-adapted lodgepole pine (Pinus contorta var. latifolia Dougl. ex. Loud.) stands at the northern boundary of its range in central Yukon showed consistent increases in pine dominance following fire (Johnstone and Chapin, 
2003). Expansion of lodgepole pine communities at the species northern limit and the replacement of spruce stands by this species could have important implications for ecosystem dynamics and natural fire regimes.

To the knowledge of the author, few studies of historical fire regimes extending beyond the documented period of observation have been carried out in Yukon Territory. Pellow (2006) developed a fire history reconstruction from southeast Yukon Territory spanning the Holocene period using macroscopic charcoal in lake sediment. The reconstruction indicates that the fire regime of the southeast Yukon was dynamic and responded to changes in climate and vegetation composition throughout the Holocene. Pellow (2006) noted that fire frequency increased during the Early Holocene when the climate was warmer and drier than present and decreased during the Mid-Holocene when the climate became more cool and moist. A return to increased fire frequency in the Late Holocene is suggested to be associated with extensive stands of fire-prone species such as black spruce (Picea mariana (Mill.) B.S.P.) and lodgepole pine, despite the onset of a more cool and moist climate (Pellow, 2006).

In a study of post-fire regeneration in the Fox Lake region, King (2006) identified two pulses in tree recruitment which are indicative of fire events. The first pulse occurs from 1850-1860 while the second pulse begins in 1870 and is centered around 1890 . These results suggest the occurrence of two previously undocumented fire events in this region. Yalcin et al. (2006) recently developed a 1000-yr record of forest fire activity from ice cores collected from the Eclipse Icefield in Yukon Territory. The Eclipse ice cores indicate that forest fire activity varied in response to climate during the $1000-y r$ record. Forest fire activity was highest during the period 1240-1410 A.D. suggested to be 
a result of warmer and drier conditions during the fading stages of the Medieval Warm Period. Forest fire activity decreased during the Little Ice Age (LIA) when cool and wet conditions prevailed and subsequently increased in the late 1800 s corresponding with the termination of the LIA and the onset of the Klondike Gold Rush which brought a large influx of miners and settlers to Yukon (Yalcin et al., 2006).

Through an analysis of documented fire activity in central Yukon Territory, McCoy and Burn (2005) determined the incidence of lightning-ignited fires is most strongly correlated with regional temperatures (McCoy and Burn, 2005). However, they also determined that area burned and the Seasonal Severity Rating (SSR), an index of fire weather variation, were most strongly correlated with moisture-related variables. Their results suggest that moisture plays the most important role in determining fire severity in central Yukon. Using multiple General Circulation Models, McCoy and Burn (2005) project that the average annual fire incidences and area burned in central Yukon may double by 2069 as a result of climate change.

Although climate is considered to be the main driver of forest fire activity over millennial time scales in western North America, it is still unclear as to how changing climatic conditions will affect forest fire regimes in the future. In some cases, forest fire activity may increase due to warmer temperatures and decreasing precipitation (eg. Whitlock, 1993; Long et al., 1998; Hallett and Walker, 2000; Millspaugh et al., 2000; Mohr et al., 2000; Long and Whitlock, 2002). Conversely, research from Alaska suggests that warmer and dryer conditions do not necessarily induce greater fire activity but instead are associated with shifts in vegetation composition as a result of changing climatic conditions (Lynch et al., 2003, 2004b). 


\section{CHAPTER 3 \\ SITE DESCRIPTION}

\subsection{Yukon Southern Lakes Ecoregion}

Yukon Territory is comprised of five ecozones which are further classified into 23 ecoregions (Fig. 3.1). These ecoregions are defined by distinctive physiography and ecological responses to climate as expressed by the development of vegetation, soil, water and fauna.

The study area is the western portion of the 1998 Fox Lake burn located approximately 80 kilometers north of Whitehorse, Yukon Territory in the Yukon Southern Lakes (YSL) ecoregion (Fig. 3.1). The YSL encompasses an area of 29892 $\mathrm{km}^{2}$ and is characterized by rounded summits, broad valleys and large lakes (Yukon Ecoregions Working Group, 2004). The majority of the lakes and large rivers have a northwest-southeast or north-south trend, reflecting the northwest trending faults and folds in the region (Yukon Ecoregions Working Group, 2004).

The surficial geology of the YSL is dominated by till, glaciofluvial gravels and glaciolacustrine clays and silt deposited during the McConnell Glaciation (Yukon Ecoregions Working Group, 2004). The McConnell Glaciation is believed to have covered the south and central Yukon between 26000 and 10000 years ago (Jackson et al., 1991) (Fig. 3.1). At the peak of the McConnell Glaciation, the entire ecoregion was covered by ice that flowed northwest from the Cassiar Mountains and north from the eastern Coast Mountains (Jackson et al., 1991). As a result, streamlined topographical features such as moraine deposits and drumlins are abundant in this ecoregion. Further, 


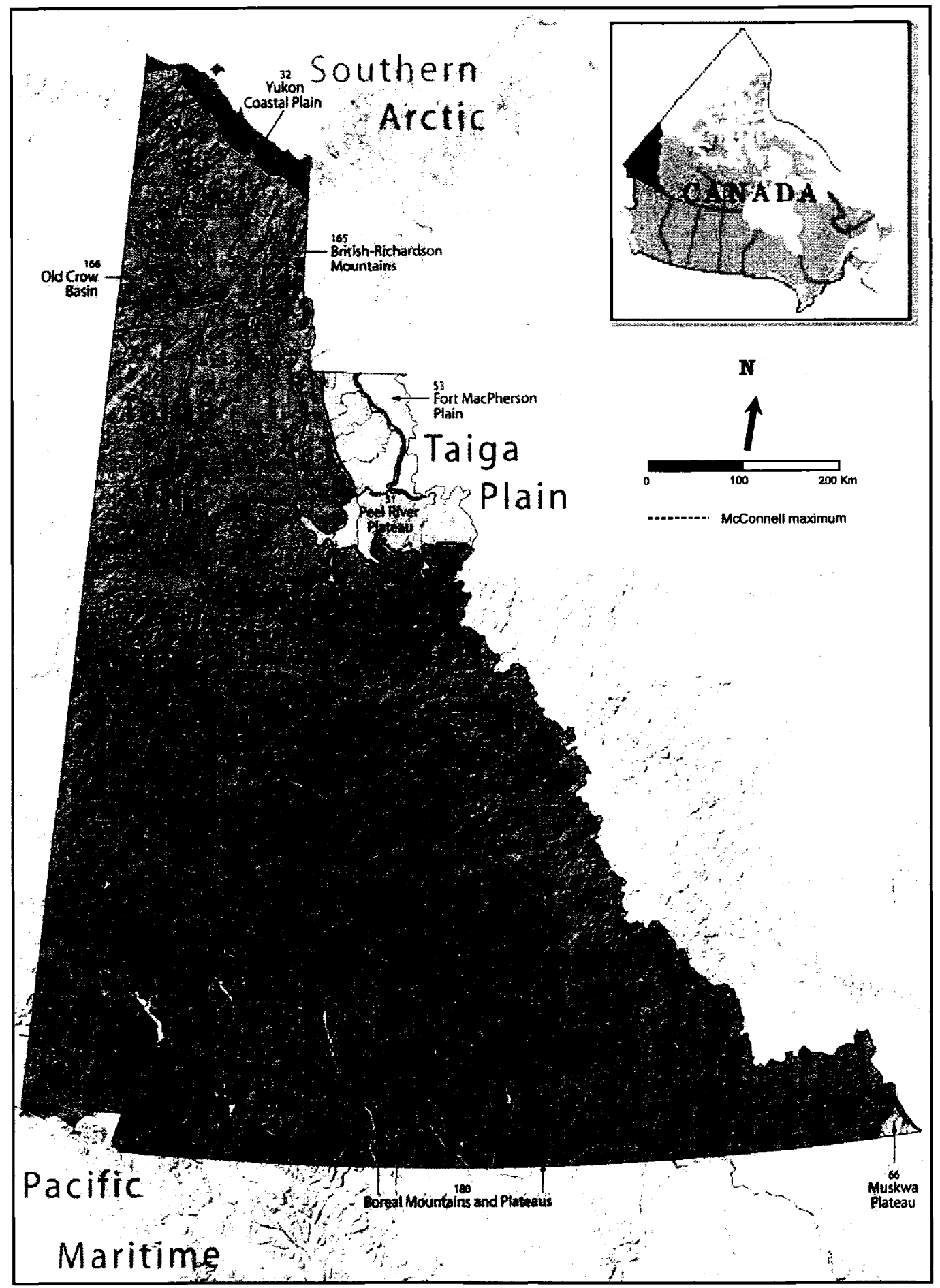

Figure 3.1: Ecozones and ecoregions of Yukon Territory (Adapted from Smith, 2004). The dashed red line indicates the limit of the McConnell Glaciation which covered eastern and southern Yukon Territory (following Duk-Rodkin, 1999). The location of the study area is indicated by a red dot. 
within the study area and the YSL the White River Ash (WRA) is prominently exposed in roadcuts and cutbanks. This tephra was deposited during the A.D. 803 eruption of Mount Churchill in the Wrangell Mountains (Clague et al., 1995). Although the WRA was deposited $\sim 1200$ years ago, it remains intact with the original buried forest floor preserved below it in many locations (Yukon Ecoregions Working Group, 2004). The reestablishment of natural vegetation communities above the WRA does not appear to have had any effect on the ash deposit.

The YSL region lies in the sporadic discontinuous permafrost zone, where less than one quarter of the landscape is underlain by permafrost (Yukon Ecoregions Working Group, 2004). Permafrost is sporadic as the ecoregion is within the rainshadow of the St. Elias Mountain which keeps the soils dry and warm in the summer (Yukon Ecoregions Working Group, 2004).

Climatic conditions over most of the ecoregion are influenced and moderated by air masses originating in the Pacific Ocean. The Gulf of Alaska is the primary source for air flow into the Yukon (Wahl et al., 1987; Anderson et al., 2005). In July, air originating in the North Pacific dominates over southern and central Yukon Territory (Bryson, 1966) as illustrated in Figure 3.2. The occurrence of Pacific air over southern and central Yukon follows the same general trend in both winter and summer months (Bryson, 1966) The Aleutian Low pressure system (AL) has a strong influence on climate throughout the Pacific Northwest (e.g. Mantua et al., 1997; Spooner et al., 2003; Anderson et al., 2005). The intensification and eastward shift of the AL results in moist, warm air transferred to western North America (Miller et al., 1994; Latif and Barnett, 1996) which delivers strong southerly winds into the mountain barrier along the Alaskan Coast. However, 


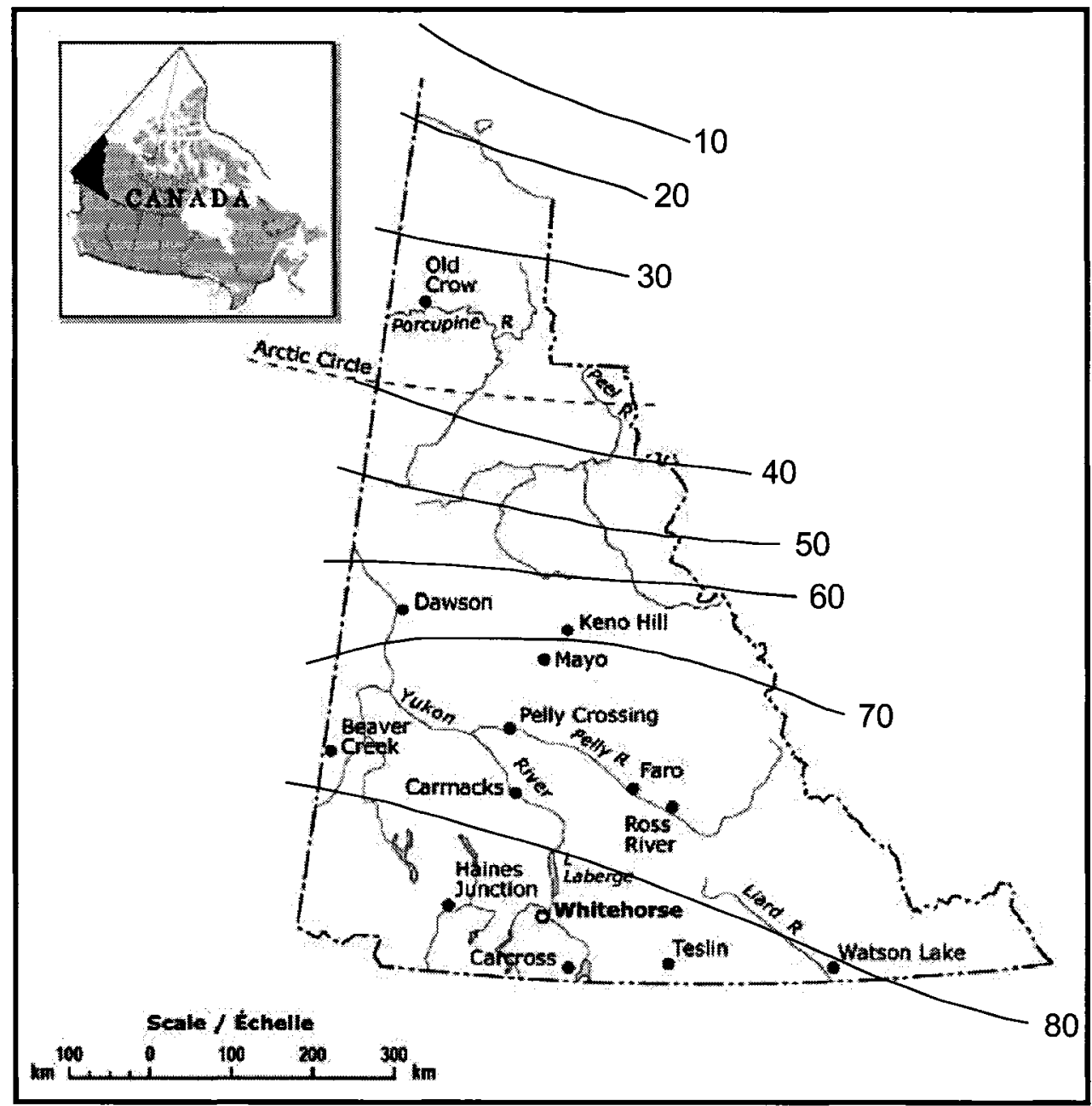

Figure 3.2: Isopleths of the percent frequency of Pacific air occurrence across Canada in July for the periods 1945-51 and 1954-56 (following Bryson, 1966). Basemap adapted from the Atlas of Canada, 2006. ${ }^{\circ}$ Her Majesty the Queen in Right of Canada. Reproduced with the permission of Natural Resources Canada. 
precipitation in the Yukon interior is low as a result of the rain shadow effect (Anderson et al., 2005). In contrast when the $\mathrm{AL}$ is westward and/or weaker, the westerly trajectory of moisture and zonal flow patterns are able to move parallel to the coastal mountain barriers and infiltrate valleys trending northeast to southwest bringing more moisture to interior Yukon (Anderson et al., 2005).

The YSL ecoregion is arid with annual precipitation ranging between 200 and 325 $\mathrm{mm} / \mathrm{yr}$ (Wahl et al., 1987; Wahl, 2004). One third to one half falls during the summer and a second maximum occurs in the fall and early winter. Snow remains on the ground from late October to mid-April in valleys and until May at higher elevations. Mean annual temperature ranges between $-1^{\circ} \mathrm{C}$ and $-4^{\circ} \mathrm{C}$ (Wahl et al., 1987; Wahl, 2004). Large lakes in the YSL act to moderate local temperatures. In the vicinity of large lakes, spring can be delayed up to two weeks as a result of persistent ice cover (Profir, 2004; Yukon Ecoregions Working Group, 2004). In contrast, the onset of cold winter temperatures can be delayed by as much as a month due to extensive low cloud cover associated with the lakes as they freeze over in early winter (Yukon Ecoregions Working Group, 2004). The climatic conditions, numerous lakes and the access to a recently burned area within the YSL provide an excellent opportunity to examine the occurrence of forest fires in the study area.

Dominant tree species in the YSL include: black spruce, white spruce (Picea glauca (Moench) Voss), lodgepole pine, subalpine fir (Abies lasiocarpa (Hook.) Nutt.), trembling aspen (Populus tremuloides Michx.), paper birch (Betula papyrifera Marsh.) and balsam poplar (Populus balsamifera L.) (Yukon Ecoregions Working Group, 2004). The vegetation cover varies from open to closed-canopy stands of conifers and mixed 
woodlands over most plateaus and valleys. Black spruce dominates low-lying, mesic sites while well drained sites are dominated by white spruce, trembling aspen and paper birch. Pure stands of white spruce can also be found on floodplains. Black spruce has a limited distribution within the YSL and is largely restricted to the eastern portion of the ecoregion (Yukon Ecoregions Working Group, 2004). Sites with dry sandy soils or those recently burned are dominated by lodgepole pine while subalpine fir tends to dominate near treeline. Above treeline alpine dwarf shrub communities including, willow (Salix sp.), lingonberry (Vaccinium vitis-idaea L.) and bearberry (Salix uva-ursi Pursh) are important (Yukon Ecoregions Working Group, 2004)

The prevalence of wildfire in the boreal forest has lead to the adaptation of dominant tree species to fire and fire regimes characteristic of the vegetation type. Trembling aspen is a short-lived, shade intolerant species which reproduces vegetatively after fire however; seedlings can germinate on sites with exposed mineral soils (Bourgeau-Chavez et al., 2000). As a result, trembling aspen is often a pioneer species on disturbed sites. Lodgepole pine parklands are typified by frequent low-intensity surface fires unless there is a large accumulation of fuel on the surface which may lead to high-intensity stand-replacing fires. Stand-replacing fires produce conditions that are highly favourable to the regeneration of this species (Bourgeau-Chavez et al., 2000). Black and white spruces retain their lower dead branches and have low crown bases and therefore high-intensity stand-replacing fires are common in spruce stands. White spruce will sometimes regenerate within $\sim 5-10$ post-fire if the disturbance occurs in late summer during seed dispersal (Bourgeau-Chavez et al., 2000). However, white spruce is often out-competed by pioneer species (MacDonald et al., 2001). 


\subsection{Site Description}

\subsubsection{Burnt Bowl Lake}

Within the study area, the watershed of a small unnamed lake (unofficially named Burnt Bowl Lake) was selected as the study site (Fig. 3.3a and b). Burnt Bowl Lake $\left(61^{\circ} 19^{\prime} \mathrm{N}, 135^{\circ} 36^{\prime} \mathrm{W}\right)$ is at an elevation of $831 \mathrm{~m}$ above sea level (a.s.1.) and has an area of approximately 1.5 ha. In proportion to its surface area, it is a deep lake measuring $10.3 \mathrm{~m}$ in depth at its center. The lake is oval in shape and has a smooth shoreline with no inflowing or outflowing streams. Burnt Bowl Lake (BBL) is $\sim 180 \mathrm{~m}$ long and $\sim 115$ wide. The lake bottom is generally flat and has simple bathymetry. The lake is within a confined watershed bounded by relatively high and steep slopes on the north, while lower gradient slopes confine the lake on its south east and west sides. The watershed covers an area of approximately 5 ha.

The study area is located in one of the driest regions of Yukon Territory (Wahl et al., 1987; Yukon Ecoregions Working Group, 2004). Mean annual precipitation for the period 1971-2000 recorded at the Braeburn climate station, approximately $10 \mathrm{~km}$ north of the lake, is approximately $280 \mathrm{~mm} / \mathrm{yr}$. Mean annual temperature recorded at Braeburn is approximately $-3.1^{\circ} \mathrm{C}$ (Environment Canada, 2004).

Two large stand-replacing fires, ignited as a result of human activity, have been documented within the watershed (Fig. 3.4a). The most recent fire occurred in the summer of 1998 at the north end of Fox Lake. The event was a high intensity, standreplacing crown fire. Before it was extinguished, it had consumed a total of 43922 ha of forest (D. Milne, pers. comm). An earlier stand-replacing fire occurred in 1958 and 

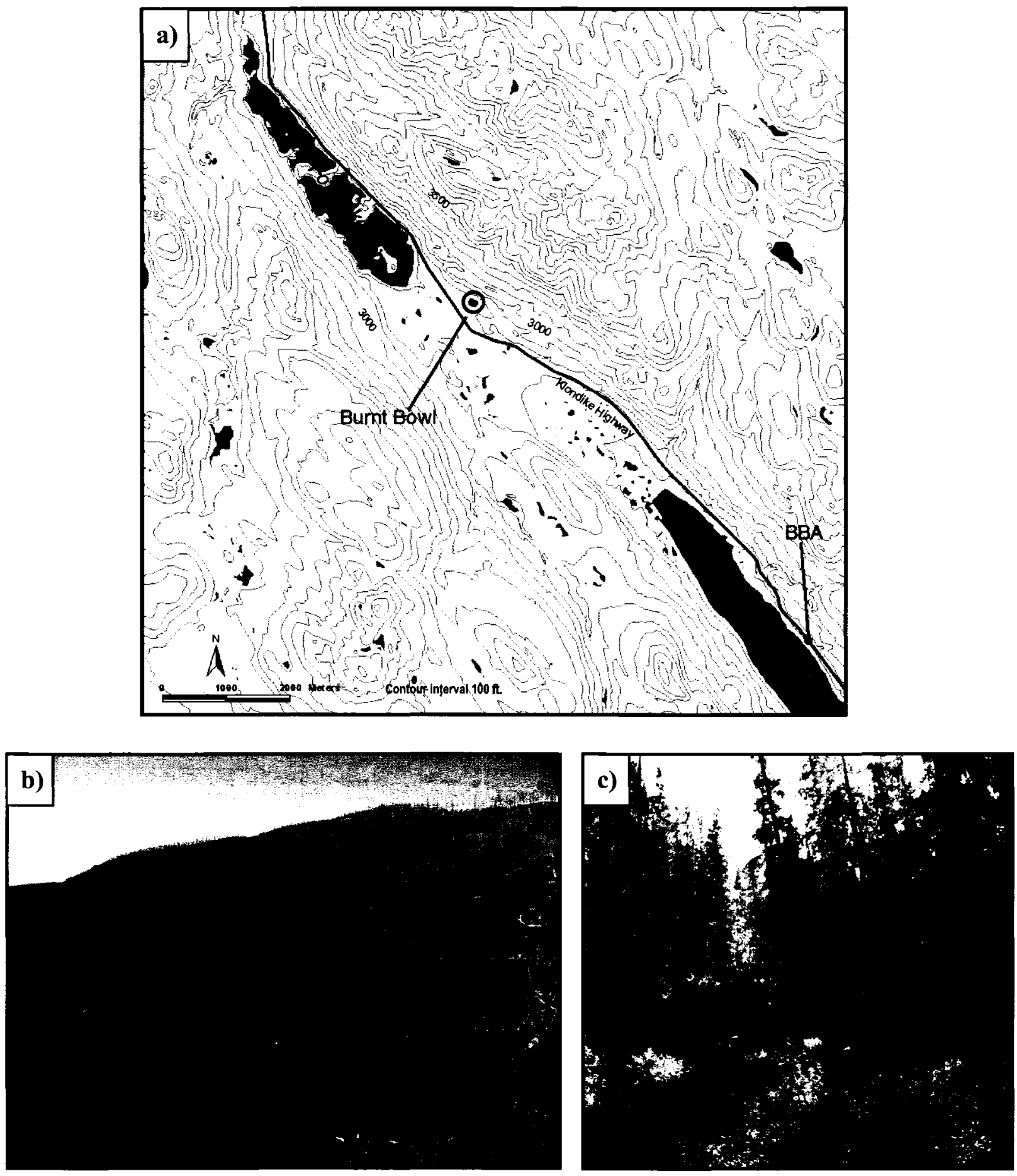

Figure 3.3: a) Topographic map showing the location of the study site within the study area (Extract of digital topographic dataset Braeburn Lake, 105E05E at 1:50 000. ${ }^{\circ} \mathrm{Her}$ Majesty the Queen in Right of Canada. Reproduced with the permission of Natural Resources Canada); b) photograph of Burnt Bowl Lake showing the steep north slope; and c) photograph of the Burnt Bowl Anchor tree ring chronology site. 

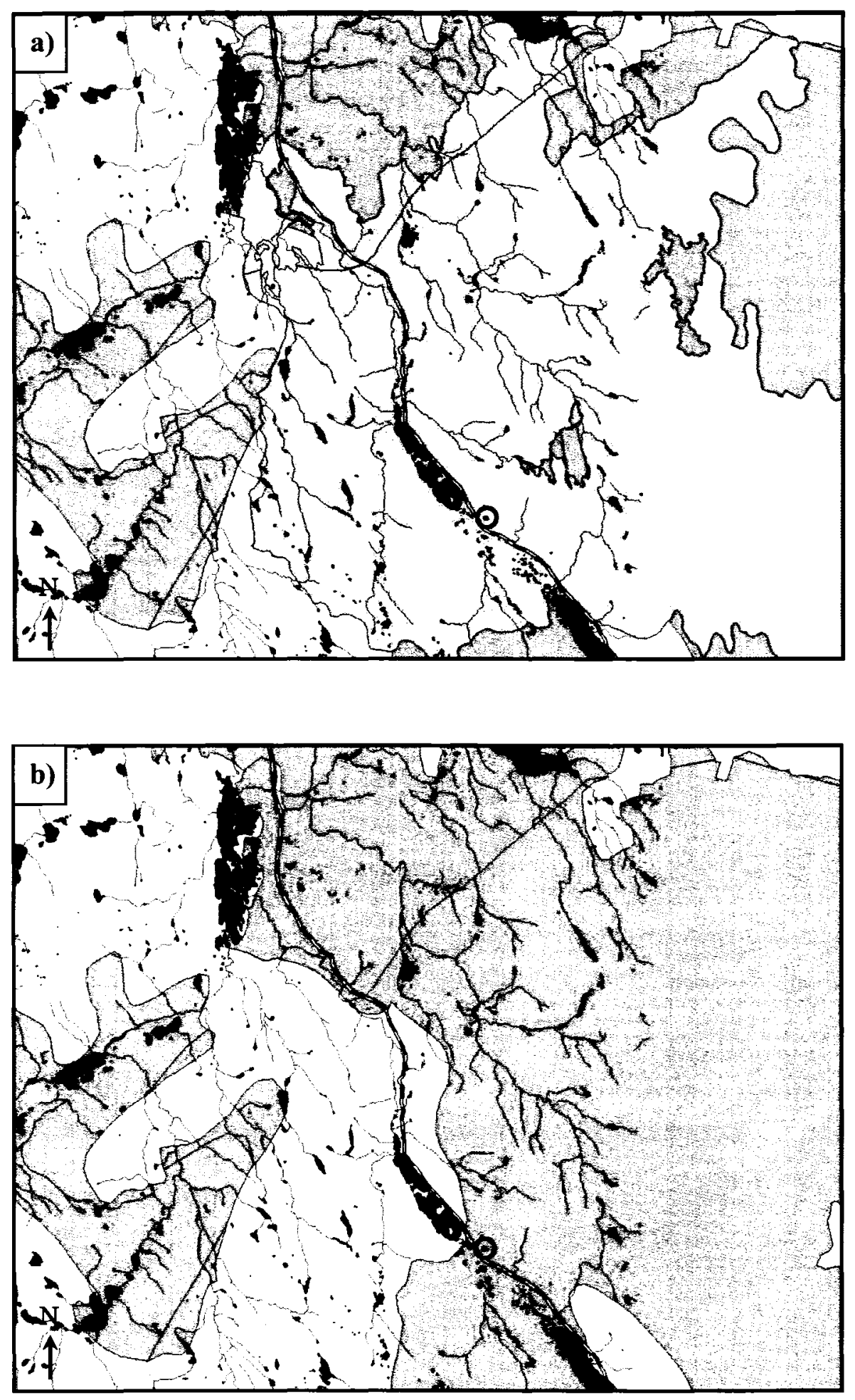

Figure 3.4: Extracts of fire history map (scale unknown) showing a) the area burned by the 1998 Fox Lake fire in pink; and b) the area burned by the 1958 Braeburn fire in yellow. Burnt Bowl Lake is circled in red. Note that the 1958 fire is documented to have consumed the study site. Map extracts provided by David Milne. 
consumed 147000 hectares before it was extinguished (D. Milne, pers. comm). Although documented on historical fire maps as occurring within the study area (Fig. 3.4b), it has been suggested that the 1958 fire may not have burned within the watershed. Instead, the uneven stand-age structure observed in this area suggests that most of the forest in this watershed were unaffected by the 1958 fire (J. Johnstone, pers. comm.). These two large fire events will serve as markers to determine if our study lake records the occurrence of local fire events. Numerous smaller fires (Fig. 3.5) have also occurred in the area over the years although only the two above mentioned fires are thought to have burnt through the study site.

The majority of trees within and around the watershed are completely charred as a result of the 1998 Fox Lake fire. Prior to the 1998 fire, the dominant tree species within the watershed included paper birch, trembling aspen and white spruce. Currently, low shrubs and herbaceous plants such as willow, alder (Alnus sp.), Labrador tea (Ledum groenlandicum Oeder), grasses (Poaceae sp.) and sedges (Cyperaceae sp.) dominate the ground cover. Fireweed (Epilobium angustifolium L.s.1.) has also become abundant in the watershed. Where mineral soils were exposed by the fire, numerous white spruce seedlings have become established.

\subsubsection{Burnt Bowl Anchor}

In order to facilitate the absolute dating of the tree ring samples from Burnt Bowl Lake, a site was selected for the collection of tree ring samples from living trees. The Burnt Bowl Anchor (BBA, $61^{\circ} 16^{\prime} \mathrm{N}, 135^{\circ} 30^{\prime} \mathrm{W}$ ) is located $7.5 \mathrm{~km}$ south of Burnt Bowl 


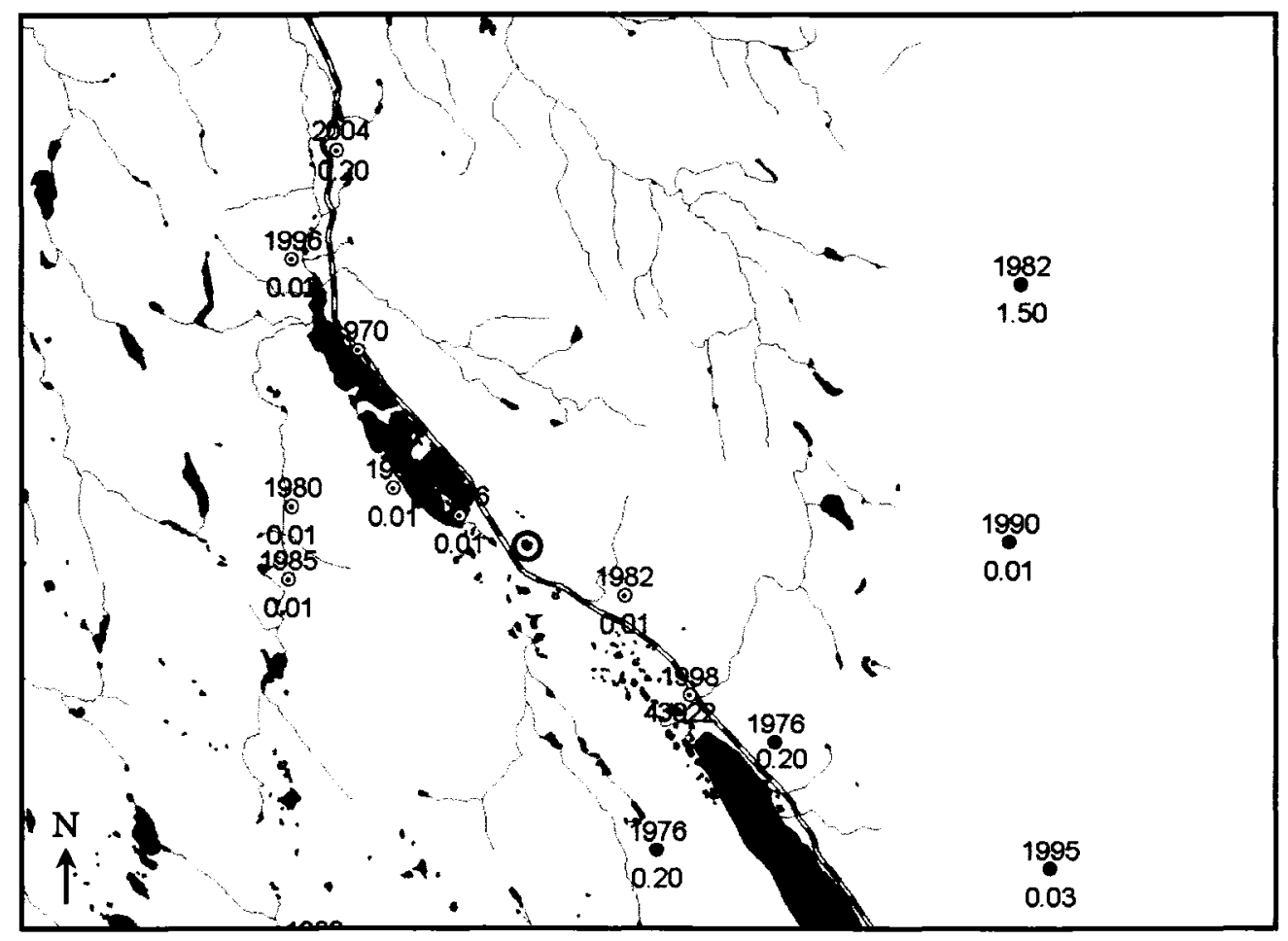

Figure 3.5: Map (scale unknown) showing the ignition points, year and the fire size (ha) at extinguishment near the study area. Red dots indicate ignition by lightning while yellow dots indicate human-caused fires. Note that the 1998 Fox Lake fire ignition point is identified on the map. Burnt Bowl Lake is circled in red. Map provided by David Milne. 
Lake on the east side of the Klondike Highway (Fig. 3.3a and c). BBA is at an elevation of $\sim 1000 \mathrm{~m}$ a.s.1. on a west-facing slope. The site is located just beyond the southern perimeter of the 1998 forest fire in order to maximize the age of the trees and the common climate signal. The dominant tree species at the BBA site are similar to those which were present at Burnt Bowl and include white spruce, trembling aspen and paper birch. 


\section{CHAPTER 4 \\ METHODOLOGY}

\subsection{Site Selection}

The development of an accurate fire history reconstruction requires careful selection of the site to be sampled. The study site selected for this research was required to meet several criteria concerning the characteristics of both the lake and the watershed. The criteria are as follows:

1. The lake had to be located within an area where fire events of known dates have occurred in order to provide a control for the sediment record.

2. The watershed should be relatively small as large watersheds provide a large source area for charcoal, magnify allochthonous inputs and also increase the introduction of secondary charcoal, which may distort the fire signal (Whitlock and Larsen, 2001).

3. Trees suitable for dendrochronological analysis must be present within the watershed.

4. The lake should be relatively deep in proportion to its surface area in order to reduce the potential for re-mixing of the sediment due to wave action and other taphonomic processes.

5. The lake should have smooth shorelines and simple bathymetry in order to minimize the potential for differential sedimentation across the lake bottom.

6. As inflowing streams provide a source for secondary charcoal to be transported to the lake basin (Whitlock and Larsen, 2001), a lake without inflowing streams was preferentially selected.

7. The presence of riparian vegetation at the lake margin may trap secondary charcoal being introduced from erosional processes and slopewash, thus a lake with a riparian fringe was preferred.

Initial site selection was carried out by identifying potential sites on topographic map sheets within the areas known to have been burned in 1958 and 1998. Potential sites 
were further examined on aerial photographs from several time periods to evaluate the depth of the lakes, surrounding vegetation and also to determine if the lakes still exist. Lakes demonstrating fluctuations in depth and size from one aerial photograph series to another were eliminated as this may modify the sedimentation process. Ideal sites identified from the topographic map sheets and aerial photographs were then evaluated in the field for final site selection. Burnt Bowl Lake was selected for the study as it met all of the criteria listed above.

\subsection{Field Methods}

Two paleoecological approaches are used to carry out this study. The first involves an analysis of the stand-age structure, developed using dendrochronological techniques, which provides high spatial and temporal resolution. However, this method is limited by the longevity of the trees. The second approach involves the analysis of changes in macroscopic charcoal particle abundance in lake sediments which can provide a record of fire events on millennial time scales. The following section provides a description of the field methods used to collect samples for analysis.

\subsubsection{Lake Sediment Collection}

In April 2005, one surficial and two long sediment cores were collected from the centre of Burnt Bowl Lake (Fig. 4.1). The retrieval of the sediment cores was carried out using the ice cover as a coring platform. The surficial core was collected using a MaxiGlew gravity corer with an internal diameter of $7.6 \mathrm{~cm}$ (Glew, 1989) (Fig. 4.2). This core (BB-05-KB1) measured $46.5 \mathrm{~cm}$ in length and was collected from a water depth of 9.66 $\mathrm{m}$ (Table 4.1). The longer sediment cores were extracted in $1 \mathrm{~m}$ segments using a 


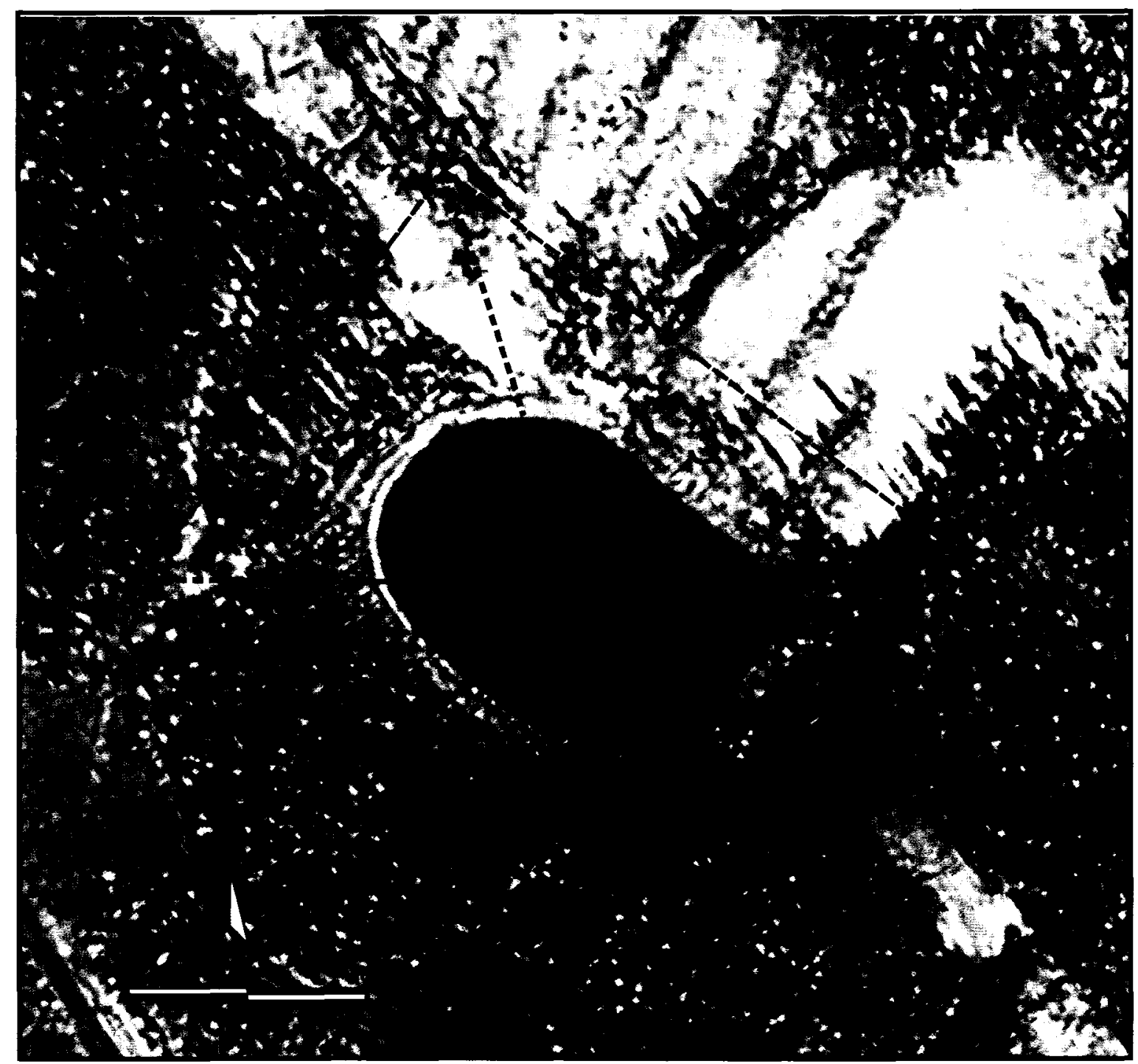

Figure 4.1: Burnt Bowl Lake showing sediment coring locations (red dots) and tree ring sampling quadrants (red dashed line) (Adapted from National Air Photo Library, aerial photograph A22197-100 at 1:15 000. ${ }^{\circ}$ Her Majesty the Queen in Right of Canada. Reproduced with the permission of Natural Resources Canada). 


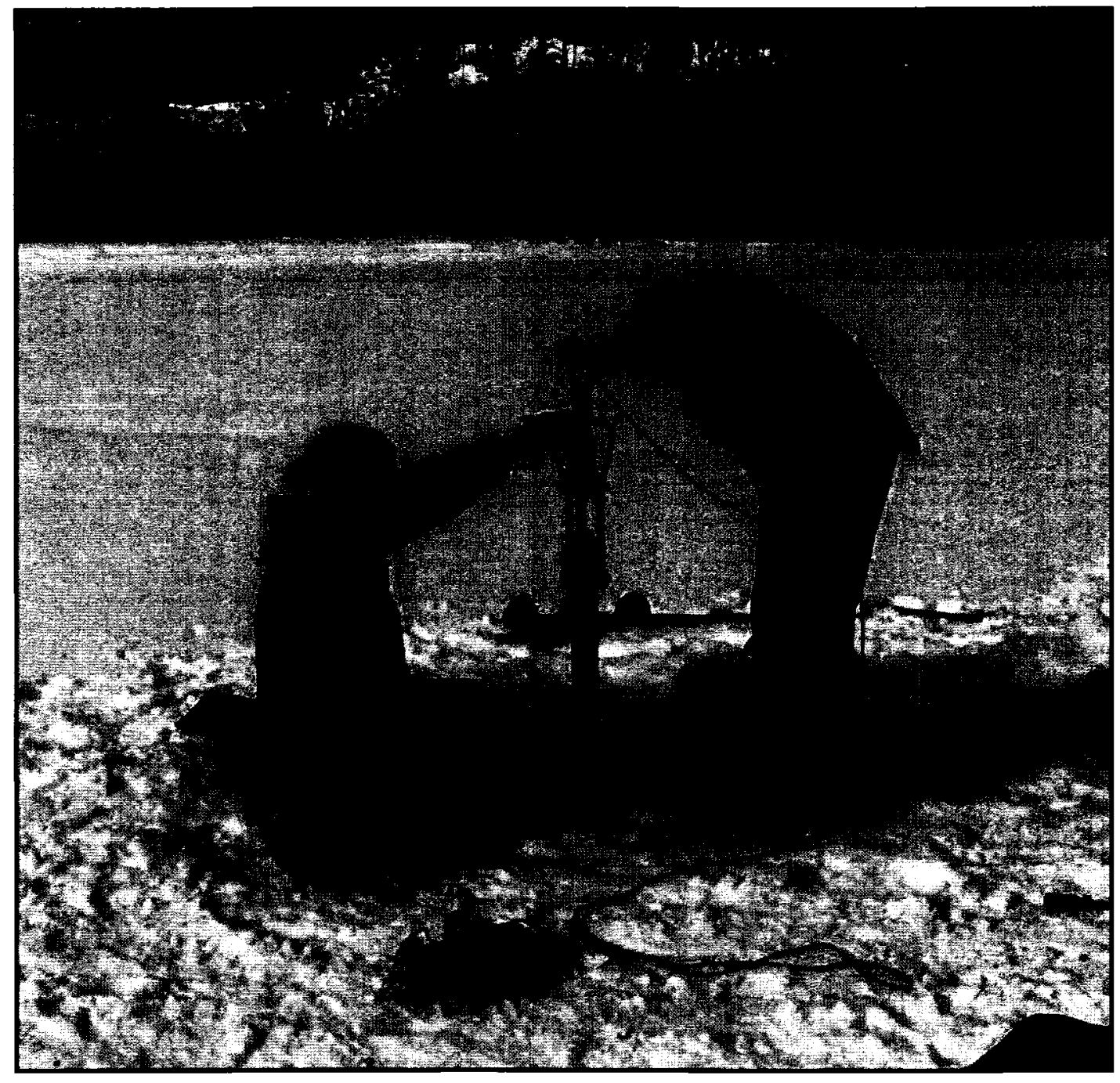

Figure 4.2: Photograph showing the collection of the surficial sediment core using a Maxi-Glew corer 
Table 4.1: Inventory of sediment cores collected from Burnt Bowl Lake.

\begin{tabular}{lllllll}
\hline Core ID & Core Type & Corer Type & $\begin{array}{l}\text { Length } \\
\text { (cm) }\end{array}$ & $\begin{array}{l}\text { Water } \\
\text { Depth } \\
\text { (m) }\end{array}$ & $\begin{array}{l}\text { Sub-sample } \\
\text { resolution } \\
\text { (cm) }\end{array}$ & $\begin{array}{l}\text { Collection } \\
\text { Date }\end{array}$ \\
\hline & & & & & & \\
BB-05-KB1 & Surficial & Maxi-Glew gravity corer & 46.5 & 9.66 & $0.5^{*}$ & April 2005 \\
BB-05-LC1 & Long core & Livingston piston corer & 198.0 & 9.66 & 1.0 & April 2005 \\
BB-05-LC2 & Long core & Livingston piston corer & 197.0 & 9.63 & 0.5 & April 2005 \\
\hline
\end{tabular}

* Sub-sampled in the field 
modified Livingston piston corer (Wright et al., 1984). (Fig. 4.1; 4.3a and b; Table 4.1). The recovery of the surficial and piston cores was such that overlap between them would create a continuous stratigraphic sequence from the surface down. The piston core segments were extruded horizontally, wrapped in cellophane and aluminium foil, packaged in individual ABS pipes, shipped back to the Carleton University Paleoecological Laboratory (CUPL) and stored in a walk-in cooler at $\sim 4^{\circ} \mathrm{C}$.

The first long core (BB-05-LC1) was recovered from $9.66 \mathrm{~m}$ of water and measured $198 \mathrm{~cm}$ (Table 4.1). The second (BB-05-LC2) measured $197 \mathrm{~cm}$ and was taken from $9.63 \mathrm{~m}$ of water (Table 4.1). In each instance, a dense layer was encountered at $\sim 194 \mathrm{~cm}$ below the sediment-water interface which appeared to be volcanic ash. This layer prevented further penetration of the Livingston corer. This layer has subsequently been identified as the White River Ash (WRA) (D. Froese, pers. comm.). Subsequent coring in 2006 was able to penetrate this ash layer and recover over $6 \mathrm{~m}$ of sediment from the lake basin. These sediments will not be analyzed for this thesis. Only LC2 was analyzed further for this study because no macrofossils for radiocarbon dating were recovered from LC1.

\subsubsection{Tree Core Collection}

Tree cores and cross-sections were collected from dead spruce trees in the BBL watershed in July 2004 and June 2005 (BB05) to identify pulse in recruitment inferred to be associated with post-fire regeneration. The watershed was divided into four quadrants associated with the cardinal directions to examine spatial burn patterns around the lake (Fig 4.1). Tree cores were colleted using a 14-inch Hagloff increment corer with an 

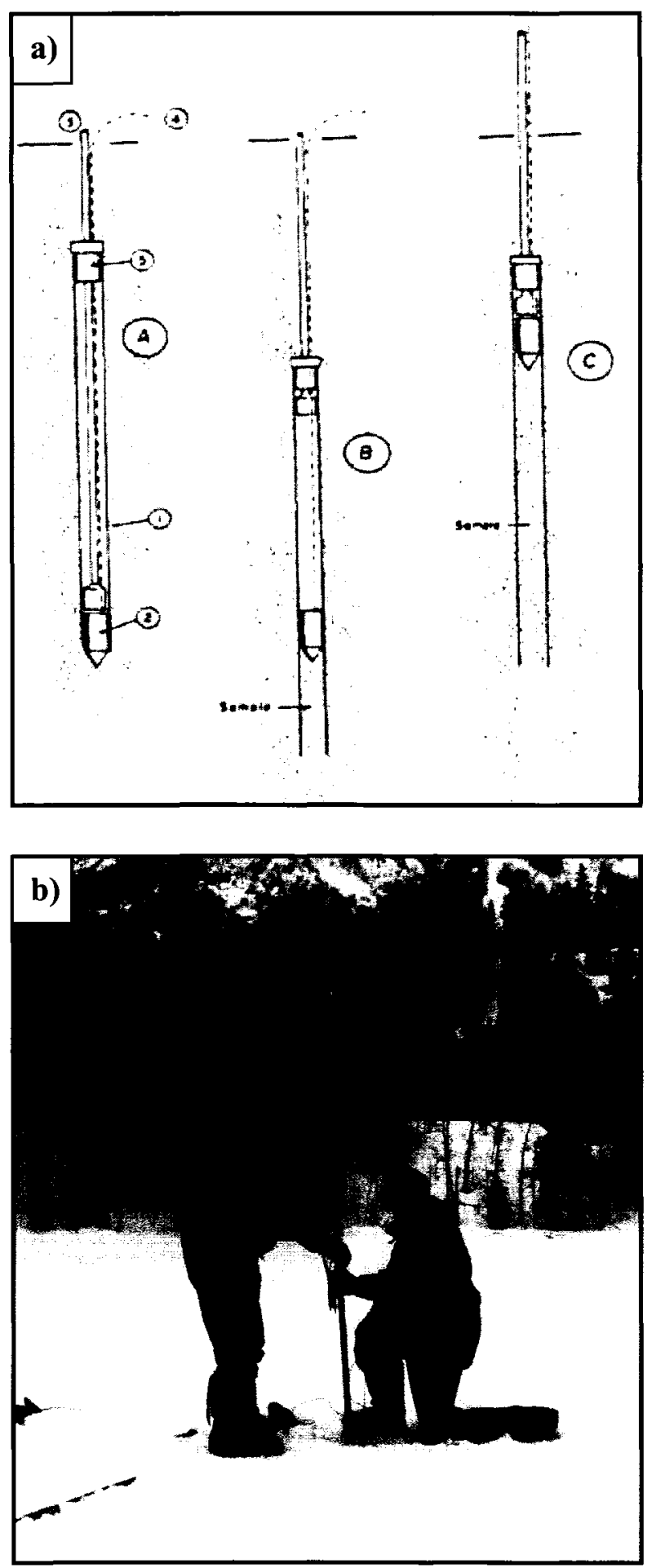

Figure 4.3: a) Diagram showing general operation of a Livingston piston corer showing (A) lowering, (B) sampling and (C) recovery. Components are numbered as follows: (1) core tube, (2) piston, (3) drive rods, (4) piston cable, and (5) drive head (Glew et al., 2001); and b) photograph showing collection of sediment cores using a Livingston piston corer system. 
inside diameter of $4.3 \mathrm{~mm}$ (Fig. 4.4a). Cross-sections were collected using a bow saw (Fig 4.4b). Cores suitable for dendrochronological fire history studies preferentially pass directly through the pith in order to accurately determine the germination date of the tree. In most cases, two cores were extracted from each tree normally from opposite sides of the stem. Tree cores and cross-sections were collected as close to the root-collar as possible in order to incorporate the maximum number of annual growth-rings (DesRochers and Gagnon, 1997). Within each quadrant, tree cores and cross-sections were collected from approximately $30-50$ trees (Table 4.2). As the site is located in a burn area, the majority of the trees that were sampled were dead. However, cores were collected from four living trees found on the southwest side of the lake in quadrant 1.

Tree cores were also collected from living white spruce trees at the BBA site located outside of the 1998 burn perimeter (Fig 3.3a and c; Table 4.2). These samples were collected in June 2005 in order to provide a living reference chronology that could be used to accurately date the dead samples from Burnt Bowl Lake. Tree cores were collected at breast height from 30 living spruce trees (Table 4.2) using the same technique described above. Cores were collected at breast height as opposed to as close to the root collar as possible because an accurate date for the establishment of each tree was not required for the reference chronology. Cross-sections were not collected at this site as we were targeting living trees. 

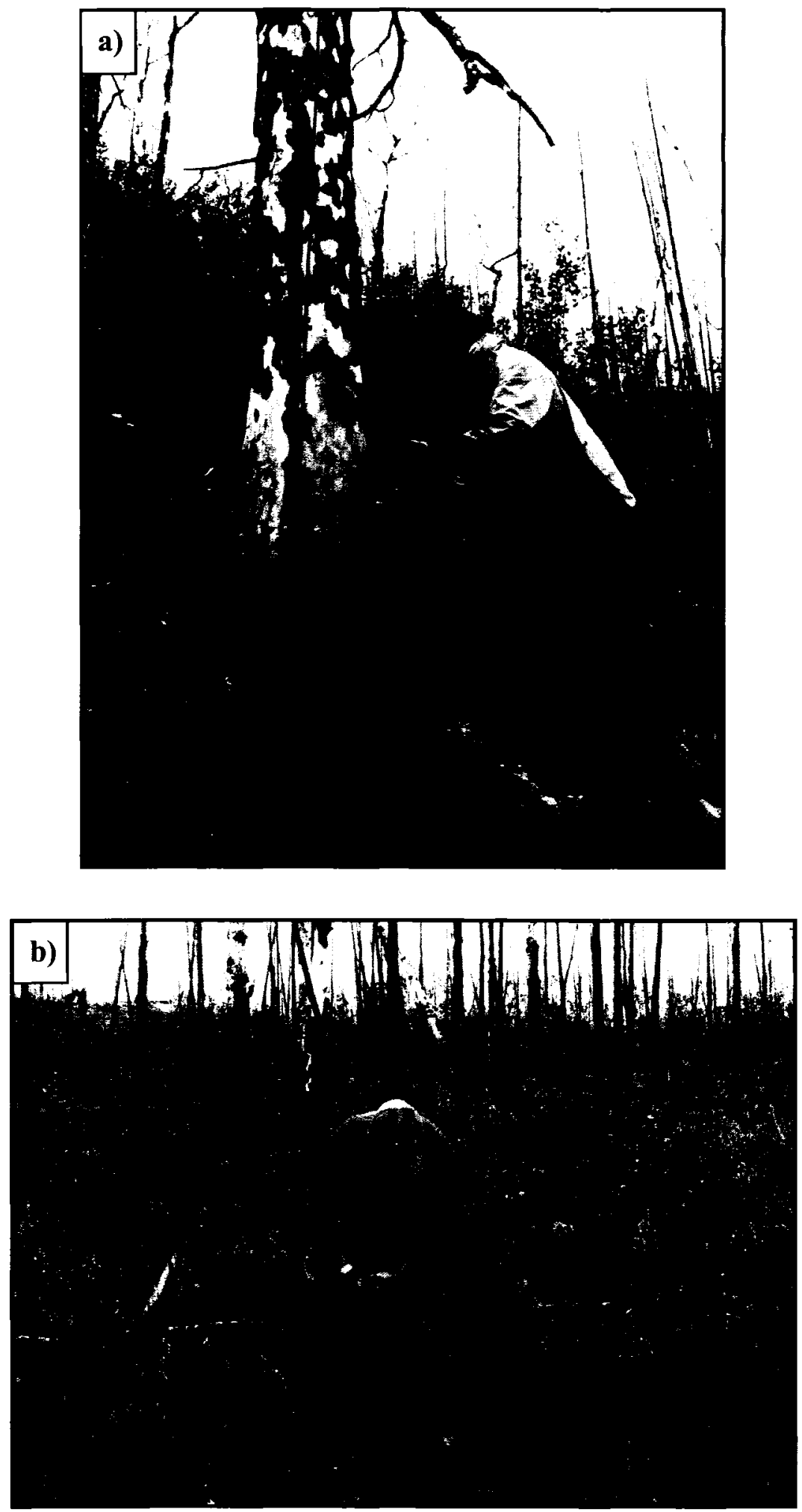

Figure 4.4: Photographs illustrating a) the collection of a tree core sample using a 14-inch Hagloff increment borer; and b) the collection of a crosssection from a charred spruce tree using a bow saw at Burnt Bowl Lake. 
Table 4.2: Tree core and cross-section inventory.

\begin{tabular}{llllll}
\hline Site & Quadrant & $\begin{array}{l}\text { Number of } \\
\text { cores/trees }\end{array}$ & $\begin{array}{l}\text { Number of } \\
\text { cross-sections }\end{array}$ & $\begin{array}{l}\text { Total \# of } \\
\text { trees } \\
\text { sampled }\end{array}$ & Collection Date \\
\hline BB05 & 1 & $40 / 20$ & 28 & 48 & July 2004, June 2005 \\
BB05 & 2 & $22 / 17$ & 23 & 40 & July 2004, June 2005 \\
BB05 & 3 & $4 / 2$ & 29 & 31 & July 2004, June 2005 \\
BB05 & 4 & $6 / 3$ & 34 & 37 & July 2004, June 2005 \\
& & $37 / 22$ & 0 & 22 & June 2005 \\
BBA & N/A & & & & \\
\hline
\end{tabular}




\subsection{Laboratory Methods}

\subsubsection{Tree Ring Sample Preparation and Analysis}

All tree cores and cross-sections were prepared using standard dendrochronological methods described in Stokes and Smiley (1968). Cores were mounted on wood slats and sanded using consecutively finer grit sandpaper starting with 80 -grit and finishing with 400-grit. Samples were sanded until the surface was highly polished and free of scratches. Once the cores were surfaced, each series was measured using a Velmex measuring system with a precision of $0.001 \mathrm{~mm}$. Each series was crossdated by matching the pattern of narrow and wide rings (Fritts, 1976), and verified using the computer program COFECHA (Holmes, 1983). In conjunction with visual crossdating, COFECHA is often used to check the accuracy of cross-dating between multiple ring-width series (Holmes, 1983). The quality of cross-dating is checked by comparing the undated series with the high-frequency variability present in all other cores from the site. This is known as the master chronology. In order to perform this check, a 32-year smoothing spline is fit to the individual series by COFECHA to remove low-frequency variance. The transformed series is then compared to the master chronology by calculating correlations at the $99 \%$ significance level for each 50 -year segment lagged by 25 years (Holmes, 1983). A reference chronology was developed using the living samples from BBA. In cases where cross-dating could not be achieved using COFECHA and through visual inspection, the core was excluded from further analysis.

Absolute-dating of cross-sections from dead samples at Burnt Bowl Lake provided a different challenge as the date coinciding with the last year of growth was unknown. COFECHA also provides a function that estimates the age of an undated 
series within the master chronology by calculating the same statistics as performed on living samples. However, if the undated series does not fall within the time period spanned by the master chronology, cross-dating is not possible at that time. In order to date dead cross-sections from Burnt Bowl Lake, ring-widths were measured along selected transects. The undated series measurements were then run through COFECHA in order to obtain an estimated date coinciding with the first year of growth. The estimated date was then temporarily assigned and the series was cross-dated by visually comparing the sequence of marker rings with the master chronology from BBA. If the marker rings coincided, the estimated date was assigned to the first year of growth. Once cross-dated, establishment dates were assigned to the pith of each sample in order to identify mass regeneration events common after a large scale disturbance. Mortality dates were also assigned to trees killed by fires in order to identify patterns of mass tree mortality.

\subsubsection{Stand-Age Structure Analysis}

Stand-age analysis was carried out by developing a frequency histogram in order to identify pulses in regeneration thought to be associated with stand-replacing fires (Kipfmueller and Baker, 1998). Establishment dates from samples at Burnt Bowl Lake were grouped into 10-year age classes and frequency histograms were developed for the site as well as for each quadrant. Only one series from each tree was used to develop the frequency histograms. 10-year age classes were selected as the ability of white spruce to regenerate after 6 years following fire is greatly reduced because the availability of suitable microsites diminishes (MacDonald et al., 2001; Purdy et al., 2002). Sudden peaks in establishment were identified in the histogram and interpreted as mass 
recruitment events following fire. Frequency histograms were also developed for each quadrant using the tree mortality data and in combination with the recruitment analysis are expected to provide a reconstruction of fire events spanning the last 200 years or more.

\subsubsection{Sediment Core Sampling}

Sediment analysis was carried out on the BB-05-KB1 and BB-05-LC2 cores. Sediment samples from BB-05-KB1 were sub-sampled and sent to the University of Ottawa for ${ }^{137} \mathrm{Cs}$ and ${ }^{210} \mathrm{~Pb}$-dating using the gamma counting technique (Appleby et al., 1986). Long cores were split lengthwise and examined for terrestrial macrofossils. Terrestrial macrofossils were extracted from LC2 at 24, 33, 59 and $193 \mathrm{~cm}$ and sent to Isotrace Laboratory at the University of Toronto for ${ }^{14} \mathrm{C}$ dating using accelerator mass spectrometry (AMS). A sample of the inferred volcanic ash layer at the bottom of the core and at $55 \mathrm{~cm}$ was collected and sent to Dr. Duane Froese in the Department of Earth and Atmospheric Science at the University of Alberta for identification using lithoprobing techniques.

\subsubsection{Age-Depth Model}

Twenty-one ${ }^{210} \mathrm{~Pb}$ age determinations were used to establish a chronology for the BB-05-KB1 surficial core. Ages were plotted against core depth to construct an agedepth curve. Linear regression, which assumes a constant sedimentation rate between dated intervals, was used to interpolate the age of the sediment intervals between the known ${ }^{210} \mathrm{~Pb}$ determinations. 
Age-depth relations for stratigraphic intervals in BB-05-LC2 were based on the

${ }^{210} \mathrm{~Pb}$ date at the bottom of $\mathrm{BB}-05-\mathrm{KB} 1, \mathrm{a}{ }^{14} \mathrm{C}$ age determination and the accepted calendar date for the deposition of the WRA of 803 A.D. (Clague et al., 1995). A constant sedimentation rate was assumed between each dated interval and linear regression was used to interpolate the age of sediments between known dates, deposition times and sedimentation rates over the length of the core.

\subsubsection{Loss-On-Ignition, Magnetic Susceptibility and Macroscopic Charcoal Analysis}

In order to identify local fire events in the watershed, three types of complimentary analyses were conducted. These techniques include: loss-on-ignition (LOI), magnetic susceptibility and macroscopic charcoal analysis. All analyses were carried out at $0.5 \mathrm{~cm}$ resolution on the BB-05-KB and BB-05-LC2 cores. LOI was completed using $1 \mathrm{~cm}^{3}$ sub-samples to identify changes in percent weight organic (LOI 550 ) and calcium carbonate ( $\mathrm{LOI}_{950}$ ) contents throughout the cores following the method of Heiri et al. (2001). Sub-samples were weighed and dried overnight at a temperature of $105^{\circ} \mathrm{C}$ in order to remove all water from the sediment. Organic matter was then oxidized by burning each sub-sample in a Fisher Isotemp programmable muffle furnace at a temperature of $550^{\circ} \mathrm{C}$ for 4 hours. Sub-samples were then placed in the muffle furnace for an additional 2 hours at $950^{\circ} \mathrm{C}$. During this second process, carbon dioxide is evolved from calcium carbonate leaving oxide (Heiri et al., 2001). The subsequent weight loss at each step is measured as a weight percentage of the original sample.

The magnetic susceptibility profile of each core was obtained by measuring $1 \mathrm{~cm}^{3}$ sub-samples using a Bartington Instruments ${ }^{\mathrm{TM}}$ MS2 magnetic susceptibility system and 
MS2B sensor. Macroscopic charcoal analysis was carried out at contiguous $0.5 \mathrm{~cm}$ intervals. Preparation and charcoal analysis of BB-05-KB1 and BB-05-LC2 was carried out using the coarse sieving method described by Millspaugh and Whitlock (1995). Using this method, $1 \mathrm{~cm}^{3}$ sub-samples were placed in a deflocculating solution of deionized water and Sparkleen ${ }^{\mathrm{TM}}$, soaked overnight and gently rinsed through a coarse sieve with a mesh size of $150 \mu \mathrm{m}$ using de-ionized water. The residue was then washed into a petrie dish for counting. Charcoal particles were identified as opaque, angular, usually planar, black fragments. Charcoal particles from each sub-sample were counted and placed into size classes by visual inspection with a Nikon $800 Z$ stereomicroscope at a magnification of $350 \mathrm{x}$. The overlap between the surficial and long core was determined by matching the LOI, macroscopic charcoal and magnetic susceptibility profiles to produce a continuous chronological sequence.

\subsubsection{CHAR Analysis and Identification of Charcoal Peaks}

Decomposition of the raw charcoal concentration time series was facilitated using the software package CHARSTER (Gavin et al., 2006). CHARSTER converts raw charcoal concentration data into pseudo-annual intervals, based on deposition time, and into charcoal accumulation rates (CHAR) at a specified time interval. The program also allows the consideration of different background and threshold values in order to identify fire episodes and produce a plot of peak frequency (Long et al., 1998; Whitlock and Anderson, 2003).

Using CHARSTER, a window width for calculating the background component and a threshold value for identifying peaks must be selected. The background CHAR component is calculated by using a moving window along the CHAR time-series and 
determining a weighted average of CHAR values for the points contained within the window (Long et al., 1998; Whitlock, 1993). The width of the window determines the smoothness of the background component. Windows that are too wide do not capture the long term variation in the CHAR data while windows that are to narrow produce a background component that mimics the peak component (Long et al., 1998; Whitlock and Anderson, 2003). The threshold value can be defined as a ratio or a difference between the CHAR and background components and is calibrated using historical and dendrochronological records to identify values of the peak component, that when exceeded, indicate a fire episode (Long et al., 1998; Gavin, 2006).

Decomposition of the CHAR record was carried out following the methods of Long et al. (1998). To facilitate comparison with other records, observations were converted so that they are regularly spaced in time. Charcoal counts were first converted to charcoal concentrations (particles $/ \mathrm{cm}^{3}$ ) and divided by deposition time (yrs/cm) to obtain pseudo-annual intervals. Using CHARSTER, the concentration values were then re-sampled at 5-year intervals and divided by the average deposition time over those intervals to produce a series of evenly spaced CHAR values (particles $/ \mathrm{cm}^{2} / \mathrm{yr}$ ) (Long et al., 1998). CHAR data, like other paleoecological data, are not normally distributed (Whitlock, 2001; Whitlock and Anderson, 2003) and therefore, were log-transformed before analysis.

Window width and the threshold parameter were determined by considering a variety of values for the two parameters and comparing the results with historical and dendrochronological records of fire for the area. Background levels were evaluated by calculating a series of locally weighted regressions using a LOWESS filter (Cleveland, 
1979) on the log-transformed CHAR data. A window width of $<25$ years tracked the CHAR record very closely while a window width $>75$ years generalized the background component obscuring known fire events. Window widths between 35 and 55 years showed similar variations in the background component and therefore an intermediate window width of 45 years was selected. Using the difference, a range of threshold values from 0.01 to $1.0 \log _{10}$ (particles $/ \mathrm{cm}^{2} / \mathrm{yr}$ ) was evaluated to identify peaks within the selected window. Three known fire events in the $20^{\text {th }}$ century were used to calibrate the threshold value. A threshold value of $0.21 \log _{10}\left(\right.$ particles $\left./ \mathrm{cm}^{2} / \mathrm{yr}\right)$ was selected as the optimal threshold because it identified only the documented fire events in the area with no additional fires between these fire events.

A peak-frequency series (fires/500 yrs) was obtained by smoothing the binary series of peaks $(1=$ peak; $0=$ no peak $)$ using a locally weighted average with a 500 -year window width. A 500-year window width was selected as opposed to the conventional 1000-year window (Long et al., 1998; Millspaugh et al., 2000; Whitlock, 2001) because of the comparatively short length of the time series. This is calculated in two steps: 1) summing the number of peaks within the window centered on each sample, and 2) smoothing this series using the tricube weighted moving average (Gavin, 2006). It is important to note that the window width becomes shorter and asymmetric towards the edges of the record so that at the very beginning and end of the record, the window is only half the length of the selected window width. As a result, the beginning and end of the peak frequency series must be interpreted with caution. 


\subsection{Investigation of the Controls on the Fire Regime}

In order to identify the main driver of forest fire regimes in south-central Yukon Territory, the fire record from this study was compared to previously published pollen and paleoclimatic records from southern Yukon Territory and Alaska. In order to investigate the possibility of fire regimes being influenced by shifts in vegetation cover as noted by research in Alaska (Lynch et al., 2003, 2004b), we first compared the fire record to the pollen assemblages from Kettlehole Pond (Cwynar, 1988) and Hail Lake (Cwynar and Spear, 1995). Changes in pollen assemblages from these lakes are in general agreement with other pollen records from Yukon Territory and northern British Columbia and can be considered representative of the Holocene vegetation history from the YSL.

We also investigate the possibility of the fire regime being controlled by changing climatic conditions during the Late Holocene period to determine if both precipitation and climate influence the occurrence of fire. The fire record was compared to a reconstruction of the Aleutian Low (AL) pressure system, as recorded in ${ }^{18} \mathrm{O}$-isotopes from Jellybean Lake in southern Yukon Territory (Anderson et al., 2005) and a surface water temperature reconstruction from Farewell Lake in Alaska (Hu et al., 2001) 


\section{CHAPTER 5 \\ RESULTS}

\subsection{Tree Ring Chronology Statistics}

A summary of the individual chronology statistics for each quadrant calculated by COFECHA is presented in Table 5.1. The chronologies range in length from 79 years (Quadrant 2; 1919-1997) to 332 years (Quadrant 1; 1672-2003). Mean sensitivity, which measures the high frequency variation in tree growth, ranges from 0.196 and 0.280 and fall within the range of 0.09-0.28 seen in other subarctic chronologies from North America (Cropper and Fritts, 1981). These values indicate that tree growth is moderately variable from year-to-year. Mean series inter-correlation, which is a measure of the strength of the relation between individual series within and the master chronology for the site, was highest for BBA (0.75) and lowest for Quadrant $1(0.439)$. Mean ring-width ranges from $0.40 \mathrm{~mm}$ in Quadrant 1 to $0.99 \mathrm{~mm}$ at BBA. Of the 172 samples collected from within the watershed, only 88 samples were accurately cross-dated and used in the stand-age structure analysis. Tree ring series were discarded if 1) the pith was not present, 2) compression wood made cross-dating difficult, and 3) the pattern of marker rings could not be visually or statistically verified using COFECHA.

\subsection{Stand-Age Structure Analysis}

Recruitment frequency histograms developed for each quadrant in the Burnt Bowl watershed are presented in Figure 5.1. In Quadrant 1, low sporadic tree recruitment occurs over the entire period of record. Small pulses in regeneration are evident beginning in the periods $1760-1770,1800-1810$ and 1890-1900. Quadrant 2 shows no 
Table 5.1: Tree-ring chronology summary statistics calculated by program COFECHA.

\begin{tabular}{llllll}
\hline & Quadrant 1 & Quadrant 2 & Quadrant 3 & Quadrant 4 & BBA \\
\hline $\begin{array}{l}\text { Total Dated } \\
\text { Series }\end{array}$ & 21 & 23 & 23 & 21 & 36 \\
$\begin{array}{l}\text { Chronology } \\
\text { Length }\end{array}$ & $1672-2003^{\mathrm{a}}$ & $1919-1997$ & $1756-1997$ & $1685-1997$ & $1814-2004$ \\
$\begin{array}{l}\text { Mean Ring- } \\
\text { width (mm) }\end{array}$ & 0.40 & 0.90 & 0.65 & 0.56 & 0.99 \\
$\begin{array}{l}\text { Mean } \\
\text { Sensitivity }\end{array}$ & 0.206 & 0.253 & 0.280 & 0.196 & 0.251 \\
$\begin{array}{l}\text { Series Inter- } \\
\text { correlation }\end{array}$ & 0.439 & 0.606 & 0.661 & 0.453 & 0.750 \\
\hline
\end{tabular}

a chronology extended to 2003 by one series. 


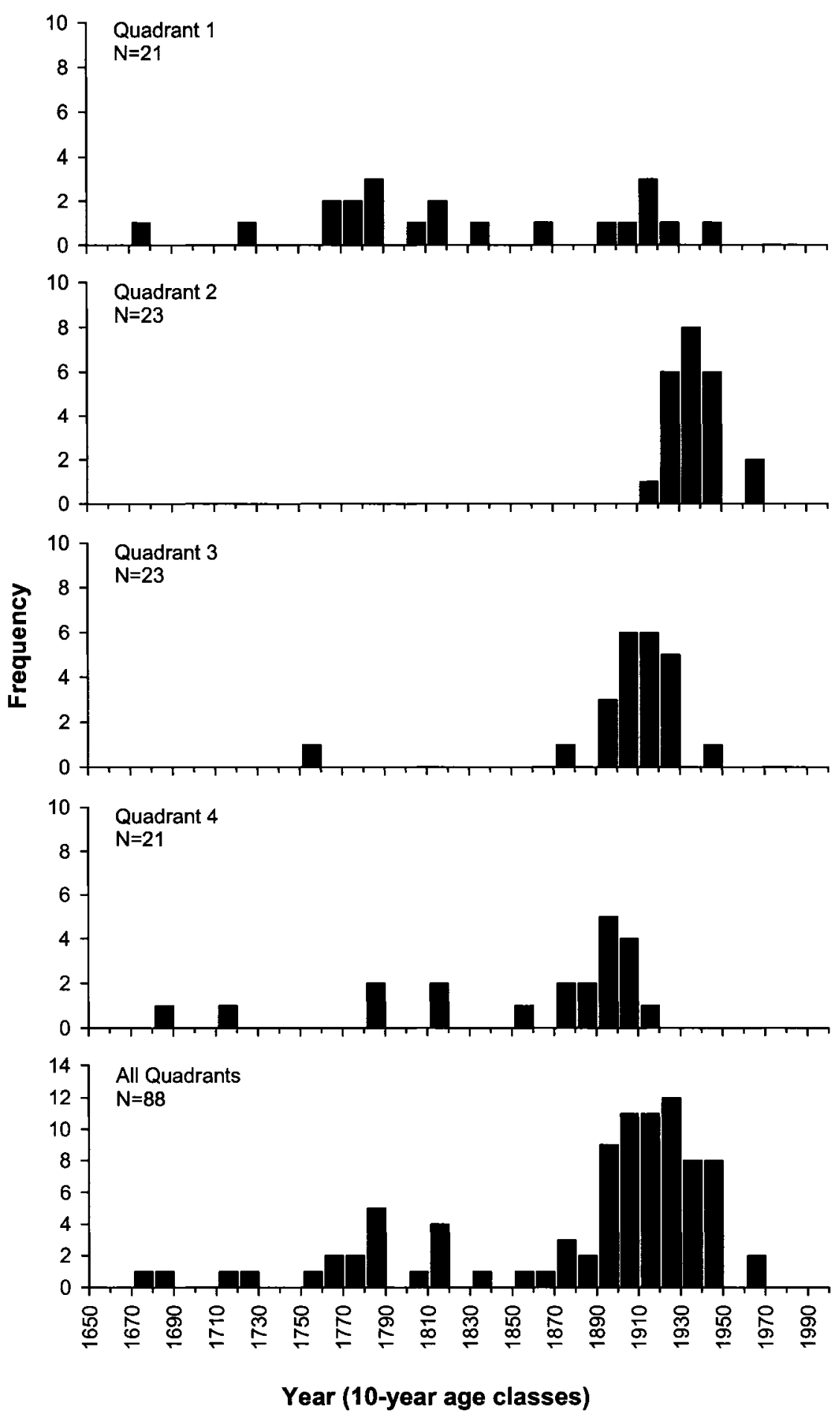

Figure 5.1: Recruitment frequency histograms for individual quadrants and combined quadrants in the Burnt Bowl watershed. Black bars represent 10-year age classes. 
recruitment before 1910, however, an abrupt increase in establishment begins at 19101920 and peaks between 1930 and 1940 . In this quadrant, $91 \%$ ( 21 trees) of the trees established between 1910 and 1949. A similar trend occurs in quadrant 3 and 4, although the timing of mass recruitment is slightly earlier in each instance. Recruitment is low in quadrant 3 with only 2 trees establishing prior to 1890 . A pulse in recruitment begins in the period $1890-1900$ and continues until 1930 . This pulse represents $87 \%$ of tree recruitment in this quadrant. Prior to 1870 , recruitment in quadrant 4 is sporadic. An increase in recruitment is evident beginning in the period 1870-1880 and peaking in the period $1890-1900$ accounting for $66 \%$ of recruitment in the quadrant.

When examining the frequency histogram of combined recruitment dates for all quadrants, one main recruitment pulse is evident commencing at $\sim 1890$ and continuing until 1950. Smaller pulses of establishment also occur at 1750-1790 and 1800-1820. These results suggest the occurrence of a fire event at $\sim 1890$. Although the two smaller pulses may suggest fire events at $\sim 1750$ and $\sim 1800$, conservative interpretation of these pulses suggest that these are not fire events based on the low number of tree establishment associated with these pulses. Of interest, when examining the timing of recruitment events in each individual quadrant, a clockwise progression in recruitment around 1900 is evident beginning in quadrant 4 on the west side of the lake and ending in quadrant 2 on the east side.

Tree mortality frequency histograms developed for individual quadrants are presented in Figure 5.2. Individual histograms show a consistent trend in tree mortality. The last complete growth ring in the majority of trees was determined to be 1996 or 1997. In the case of trees showing a complete growth ring in 1997, a partial 1998 growth 

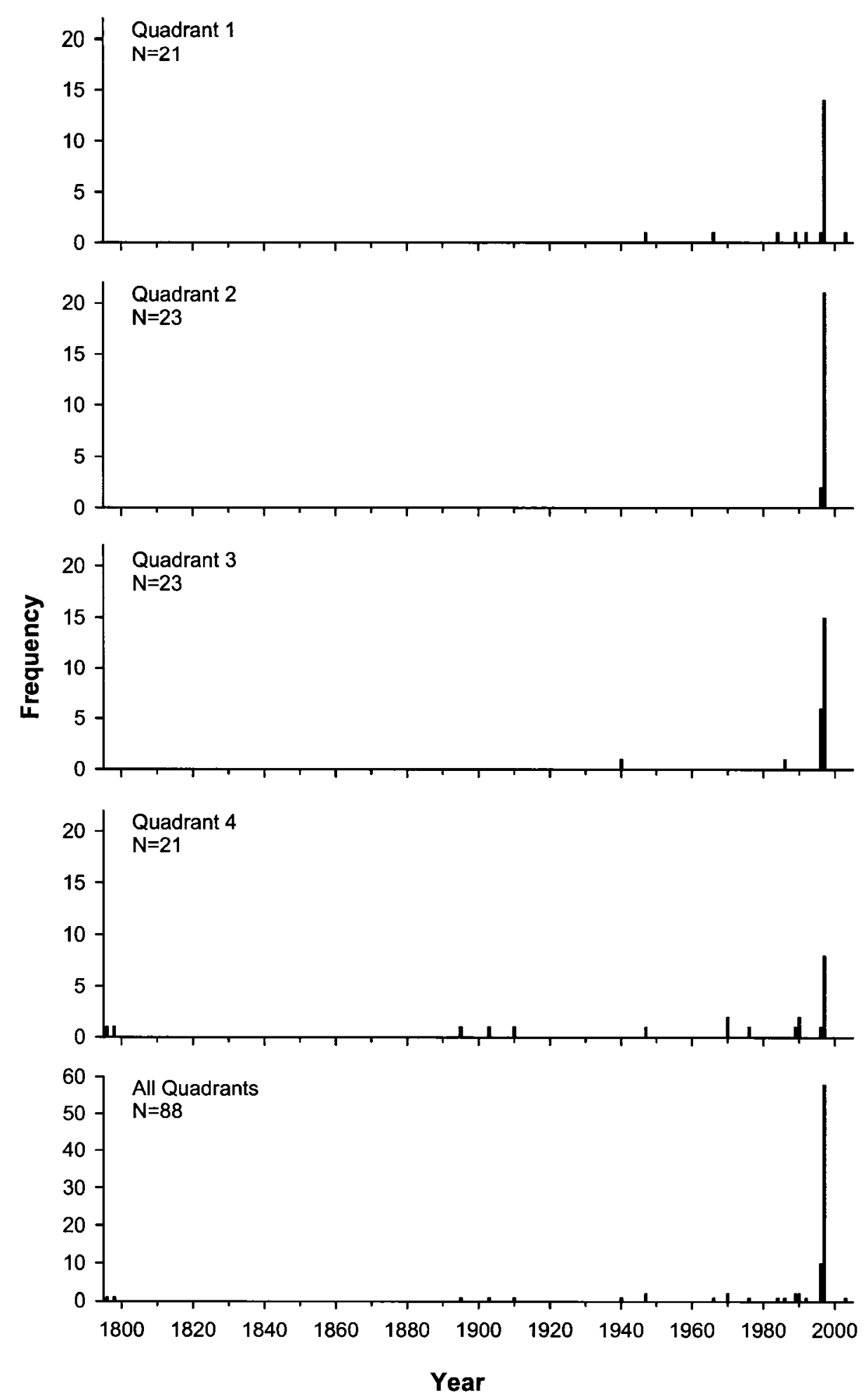

Figure 5.2: Tree mortality frequency histograms for individual quadrants and combined quadrants in the Burnt Bowl watershed. 
ring was present while a partial 1997 growth ring was present in those trees with the last complete growth ring corresponding to 1996 . In quadrant 1 , there is no tree mortality prior to 1947 . In 1998, tree mortality increased abruptly with the death of 14 trees accounting for $67 \%$ of the sampled population. In quadrant $2,100 \%$ of tree mortality occurred in 1997 and 1998. A similar trend occurs in quadrant 3 with $91 \%$ of tree mortality occurring in 1997 and 1998. Sporadic mortality occurred in quadrant 4 between 1797 and 1997 with one or two trees dying in each instance. As with the other quadrants, the greatest mortality occurred in 1998 accounting for $35 \%$ of tree mortality. The combined tree mortality data for all quadrants demonstrates that $77 \%$ ( 68 trees) of tree mortality occurred in 1997 and 1998. Throughout other portions of the period of record, tree mortality is low with one or two trees dying in each instance. In addition to 1997 and 1998, only two other dates are replicated between multiple quadrants. In 1948 and 1990, single tree mortality occurred in quadrants 1 and 4.

\subsection{Sediment Core Chronology}

The KB and LC2 cores were matched by comparing LOI, magnetic susceptibility and macroscopic charcoal counts for the area of overlap in order to provide a continuous core sequence. The total length of sediment core was subsequently adjusted to a length of $226.5 \mathrm{~cm}$ to reflect the overlap.

The sediment core chronology is based on ${ }^{210} \mathrm{~Pb},{ }^{137} \mathrm{Cs}$ and ${ }^{14} \mathrm{C}$ dates and the accepted age of the White River Ash layer. Using the Constant Flux:Constant Sedimentation model (CF:CS; Robbins, 1978), 21 dates were determined for the KB core based on measured ${ }^{210} \mathrm{~Pb}$ and ${ }^{137} \mathrm{Cs}$ activity (Fig 5.3). Lithoprobe analysis confirmed that both of the volcanic ash layers derived from the White River eruption (D. Froese, pers. 


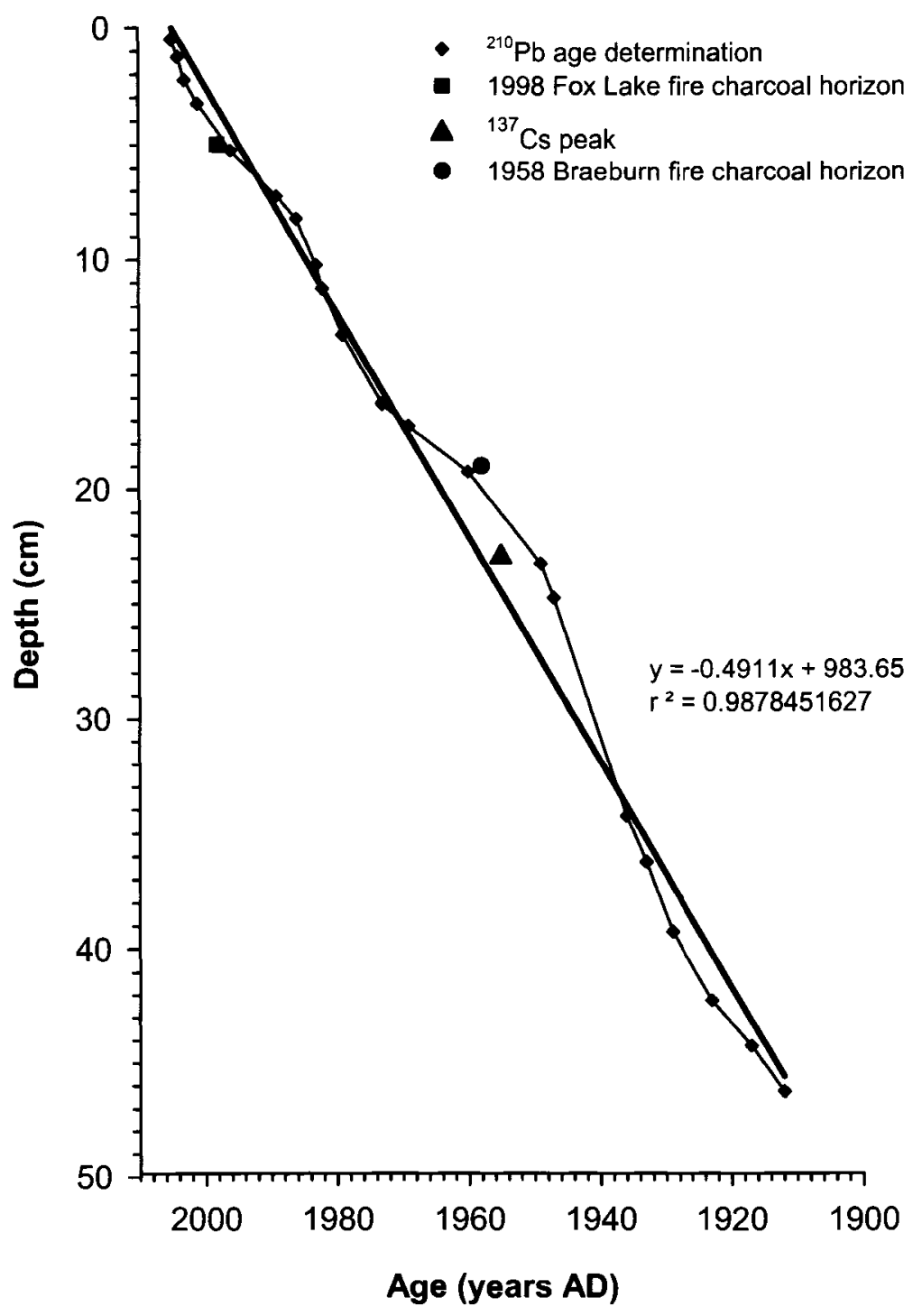

Figure 5.3: Burnt Bowl Lake surface sediment ${ }^{210} \mathrm{~Pb}$ ages (BB-05$\mathrm{KB} 1$ ) from constant mass sedimentation (CF: CS) age model. 
comm.). The White River tephra has a mean calendric age of 1147 cal. years B.P (803

A.D.) determined from four ${ }^{14} \mathrm{C}$ dates on stumps buried in the tephra (Clague et al., 1995).

Only one radiocarbon data was included in the final chronology (Table 5.2). Age determinations for the sediment intervals at $51.5 \mathrm{~cm}, 60.5 \mathrm{~cm}$ and $220.5 \mathrm{~cm}$ were not used in the age chronology because macrofossils at 51.5 and $60.5 \mathrm{~cm}$ returned modern calibrated dates wheras the date returned for the interval at $220.5 \mathrm{~cm}$ was older than the White River tephra deposit located further downcore (Table 5.2). A calibrated age of ca. 1810 A.D. was determined for the depth of $86.5 \mathrm{~cm}$ (Table 5.2). This represents the midpoint for this date; however, it is associated with significant uncertainty (Fig. 5.4) and must be interpreted with caution. As a result, the age-depth model for Burnt Bowl Lake was constructed using ${ }^{210} \mathrm{~Pb}$ and ${ }^{137} \mathrm{Cs}$, the calibrated age of the sediment interval at $86.5 \mathrm{~cm}$ and the White River ash at $221.5 \mathrm{~cm}$ (Fig. 5.4). The chronology indicates variable sedimentation rates throughout the upper portions of the core. Sedimentation rates range from $0.22-1.00 \mathrm{~cm} / \mathrm{yr}$ with a mean sedimentation rate of $0.491 \mathrm{~cm} / \mathrm{yr}$. between 0 and $46 \mathrm{~cm}$. We extended this mean sedimentation rate down to a depth of $86.5 \mathrm{~cm}$ because of the uncertainty associated with the ${ }^{14} \mathrm{C}$ date at this interval. Sedimentation rates decrease downcore between 86.5 and $221.5 \mathrm{~cm}$ to a sedimentation rate of 0.135 $\mathrm{cm} / \mathrm{yr}$.

\subsection{Sedimentology}

The $226.5 \mathrm{~cm}$ sediment stratigraphy is composed of fine grained gyttja with minor mineral matter content interrupted by abrupt shifts in sediment lithology to denser sediments composed of a coarse grain sand/gyttja mix (Fig. 5.4). The fine grain gyttja is 
Table 5.2: $\mathrm{AMS}{ }^{14} \mathrm{C}$ dates for Burnt Bowl Lake.

\begin{tabular}{|c|c|c|c|c|c|c|c|}
\hline Lab no. & $\begin{array}{l}\text { Core depth } \\
\text { (cm) }\end{array}$ & Material & $\begin{array}{l}\text { Weight } \\
\text { (mg) }\end{array}$ & $\begin{array}{l}\text { Uncalibrated age } \\
\left({ }^{14} \mathrm{C} \text { yr. B.P. }\right)\end{array}$ & $\begin{array}{l}{ }^{14} \mathrm{C} /{ }^{12} \mathrm{C} \\
(\mathrm{pMC})\end{array}$ & $\begin{array}{l}\text { Calibrated } \\
\text { age }\end{array}$ & 2-Sigma Range \\
\hline TO-12408 & $51.5^{\mathrm{a}}$ & Conifer needle & 7.2 & & $119.94 \pm 0.95$ & $\begin{array}{l}1959 \text { A.D. } \\
1985 \text { A.D. }\end{array}$ & $\begin{array}{l}1958 \text { - } 1959 \text { A.D. } \\
1981 \text { - } 1989 \text { A.D. }\end{array}$ \\
\hline TO-12409 & $60.5^{a}$ & Conifer needle & 2.9 & & $111.67 \pm 0.73$ & $\begin{array}{l}1958 \text { A.D. } \\
1994 \text { A.D. }\end{array}$ & $\begin{array}{l}1957 \text { - } 1958 \text { A.D. } \\
1990 \text { - } 1999 \text { A.D. }\end{array}$ \\
\hline TO-12925 & 86.5 & Leaf & 6.3 & $130 \pm 70$ & & $\begin{array}{l}1690 \text { A.D. } \\
1725 \text { A.D. } \\
1810 \text { A.D. } \\
1950 \text { A.D. } \\
1950 \text { A.D. }\end{array}$ & $\begin{array}{l}1645 \text { - } 1955 \text { A.D. } \\
1645 \text { - } 1955 \text { A.D. } \\
1645 \text { - } 1955 \text { A.D. } \\
1645 \text { - } 1955 \text { A.D. } \\
1645 \text { - } 1955 \text { A.D. }\end{array}$ \\
\hline TO-12411 & $220.5^{\mathrm{a}}$ & Conifer needle & 1.3 & $2220 \pm 70$ & & $\begin{array}{l}2300 \text { B.P. } \\
2235 \text { B.P. } \\
2180 \text { B.P. }\end{array}$ & $\begin{array}{l}2350-2040 \text { B.P. } \\
2350-2040 \text { B.P. } \\
2350-2040 \text { B.P }\end{array}$ \\
\hline GSC-5617 ${ }^{b}$ & 221.5 & White River Ash & & $1430 \pm 70$ & & 1147 B.P. & $1014-1256$ B.P. ${ }^{b}$ \\
\hline
\end{tabular}

${ }^{\mathrm{a}}$ Rejected

${ }^{b}$ Clague et al., 1995 


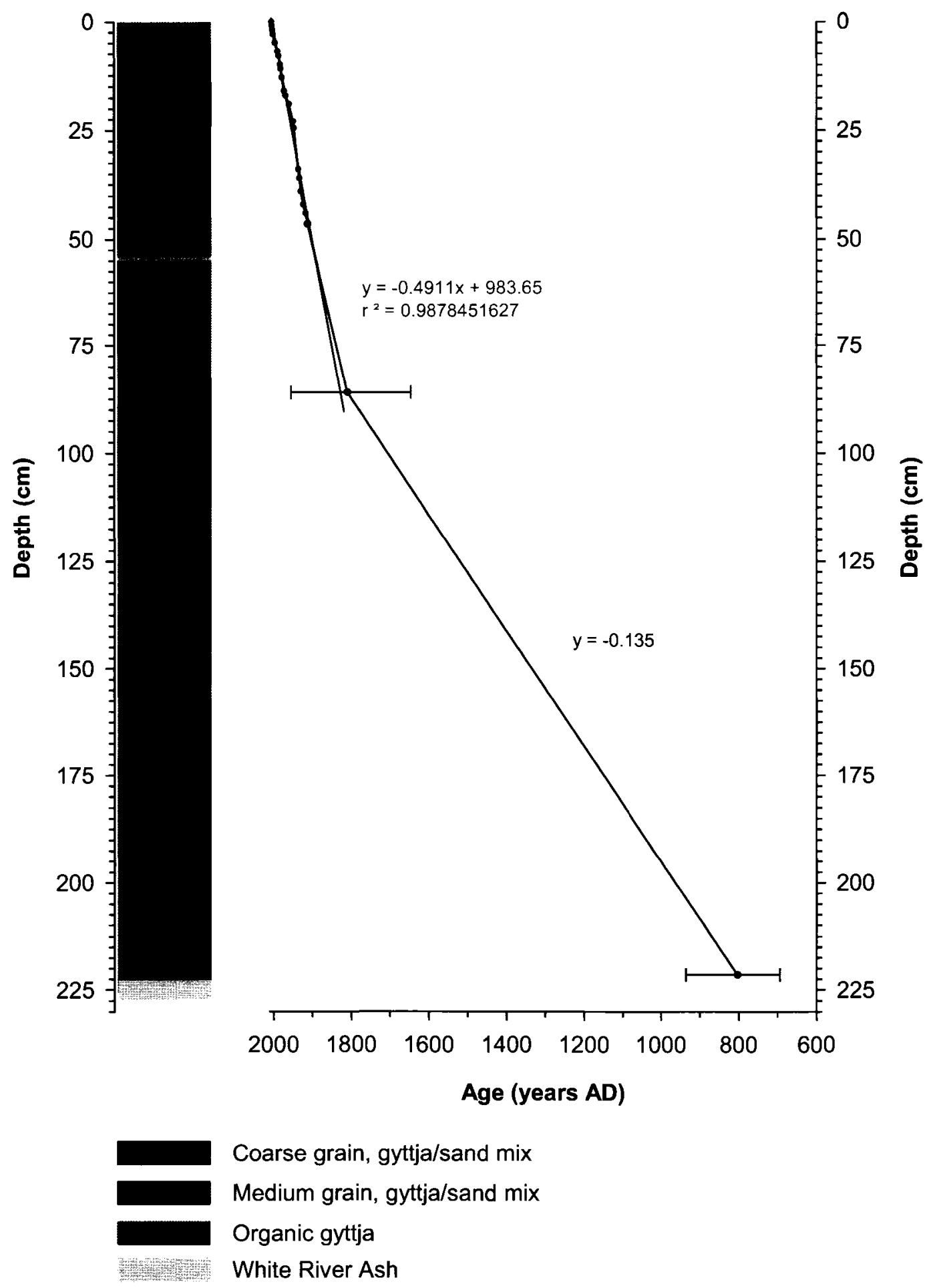

Figure 5.4: Age-depth model and profile of the surficial and LC2 sediment cores from

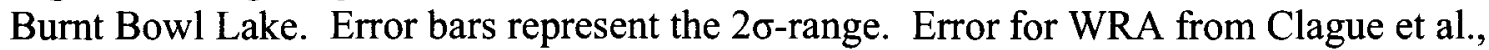
1995. 
light brown in color while the coarse grain gyttja/sand mix is dark brown to black. Abrupt shifts in sediment lithology occur frequently in the upper portion of the core between 0 and $110 \mathrm{~cm}$. These shifts occur at $6.5,13,38,46,54$ and $89.5 \mathrm{~cm}$. In contrast, the lower portion of the core is dominated by fine grained gyttja with only two shifts to coarser sediments at 149 and $170 \mathrm{~cm}$. Deposits from the White River eruption are evident at 55 and $221.5 \mathrm{~cm}$. The first deposit at $55 \mathrm{~cm}$ is $0.5 \mathrm{~cm}$ thick, likely re-deposited as a result of the re-activation of the terrestrial landscape, while the deposit at $221.5 \mathrm{~cm}$ is more prominent extending over the last $5 \mathrm{~cm}$ of the core.

\subsection{Sediment Properties}

Results of the LOI, magnetic susceptibility measurements and macroscopic charcoal analysis are presented in Figure 5.5. $\mathrm{LOI}_{550}$ analysis reveals that the organic content is quite variable between 226.5 and $111.0 \mathrm{~cm}$ (Fig. 5.5b). Organic content decreases abruptly in the presence of coarse grained sediments between $110.5-91 \mathrm{~cm}, 76-$ $60 \mathrm{~cm}$ and 25 to $0 \mathrm{~cm}$ (1946-present). Higher $\mathrm{LOI}_{550}$ values occur between $91-77 \mathrm{~cm}, 60$ $25 \mathrm{~cm}$ and near $10 \mathrm{~cm}$. $\mathrm{LOI}_{950}$ analysis indicates that $\mathrm{CaCO}_{3}$ rises and falls in synchrony with organic content (Fig. 5.5c).

Magnetic susceptibility (Fig. 5.5d) and charcoal concentrations (Fig. 5.5e) appear to demonstrate an inverse relation with organic and $\mathrm{CaCO}_{3}$ content. Magnetic susceptibility is generally low from the base of the core to $111.0 \mathrm{~cm}$. Two peaks occur in the bottom portion of the core at $221.5 \mathrm{~cm}$ (ca.800 A.D.; $17.1 \mathrm{SI}$ ) and $171.5 \mathrm{~cm}$ (ca. 1200 A.D.; $88 \mathrm{SI}$ ) (Fig. 5.5d). From $111 \mathrm{~cm}$ to the top of the core, magnetic susceptibility
readings are highly variable with values ranging from 2.9 to 120.5 SI (Fig. 5.5d). Peaks
within this period match peaks in the charcoal record. 


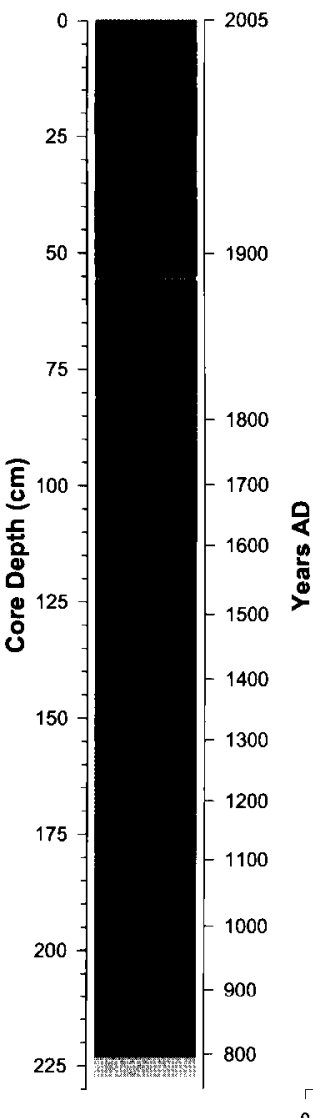

b)
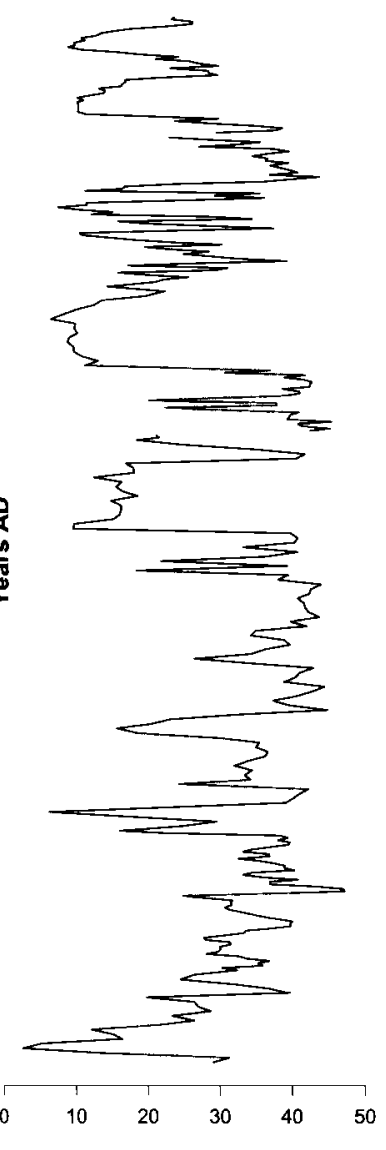

$\%$ Organic c)

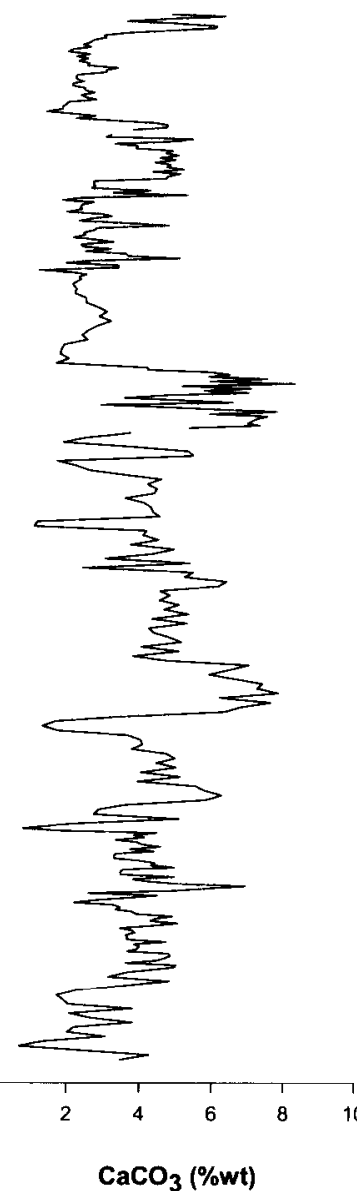

d)
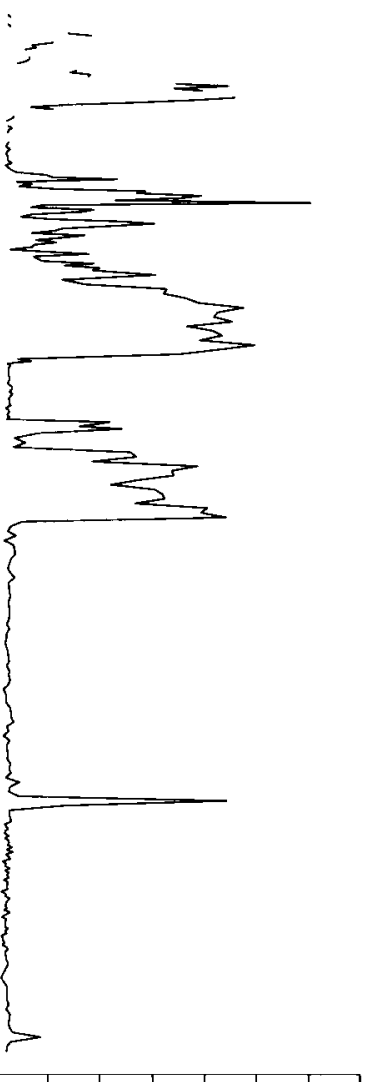

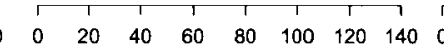

Magnetic Susceptibility

$$
\left(\times 10^{-6} \mathrm{SI}\right)
$$

e)

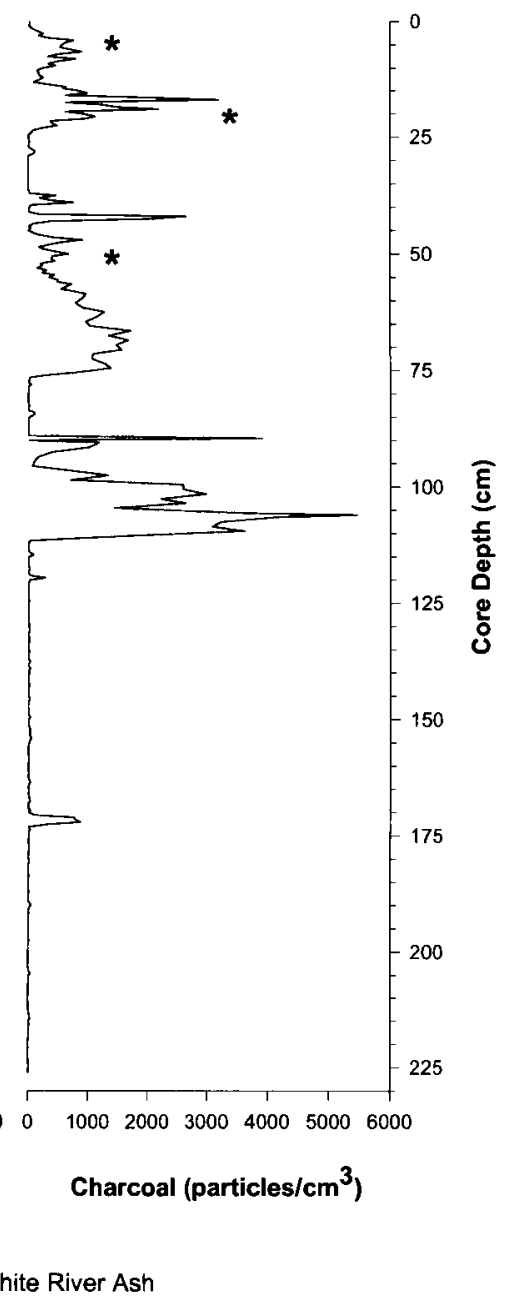

Figure 5.5: Burnt Bowl Lake sediment properties including a) sediment core profile, b) percent organic content $\left(\mathrm{LOI}_{550}\right)$, c) percent calcium carbonate ( $\left.\mathrm{LOI}_{950}\right)$, d) magnetic susceptibility, and e) charcoal concentration with know fire events in 1998, 1958 and 1890 indicated by asterisks 
In the bottom half of the core, charcoal concentrations are low and mirror the magnetic susceptibility profile (Fig. 5.6a and b). Low charcoal concentrations occurbetween 226.5 and $111.0 \mathrm{~cm}$ with minor peaks occurring at 119.5 (273 particles $\left./ \mathrm{cm}^{3}\right)$ and $114.5 \mathrm{~cm}\left(86\right.$ particles $\left./ \mathrm{cm}^{3}\right)$ and a larger peak at $172 \mathrm{~cm}(874$ particles $/ \mathrm{cm}^{3}$.). In the top $111 \mathrm{~cm}$ of the core, charcoal concentrations exhibit high variability with numerous peaks ranging from $757-5457$ particles $/ \mathrm{cm}^{3}$. Increases in magnetic susceptibility and charcoal concentrations occur in synchrony with the exception of two stratigraphic interval at 162.5 and $205 \mathrm{~cm}$ (Fig. 5.6a and b) When compared with the sediment stratigraphy, these results indicate that coarse grain sediments low in organic content are likely deposited into the Burnt Bowl Lake basin during fire events (Fig. 5.5).

\subsection{Charcoal Accumulation Rates (CHAR)}

The log-transformed CHAR data interpolated to 5-year age intervals show trends similar to those identifiable in the charcoal concentration record (Fig. 5.7a and 5.5e). Low CHAR values occur in the bottom portion of the core with the exception of several peaks occurring at ca. $925,1030,1165,1300,1555$ and 1590 A.D. This period of low CHAR values is followed by a period of high variability with abrupt shifts between low and very high CHAR values from $1600-2000$ A.D. (Fig. 5.7a). 
a)

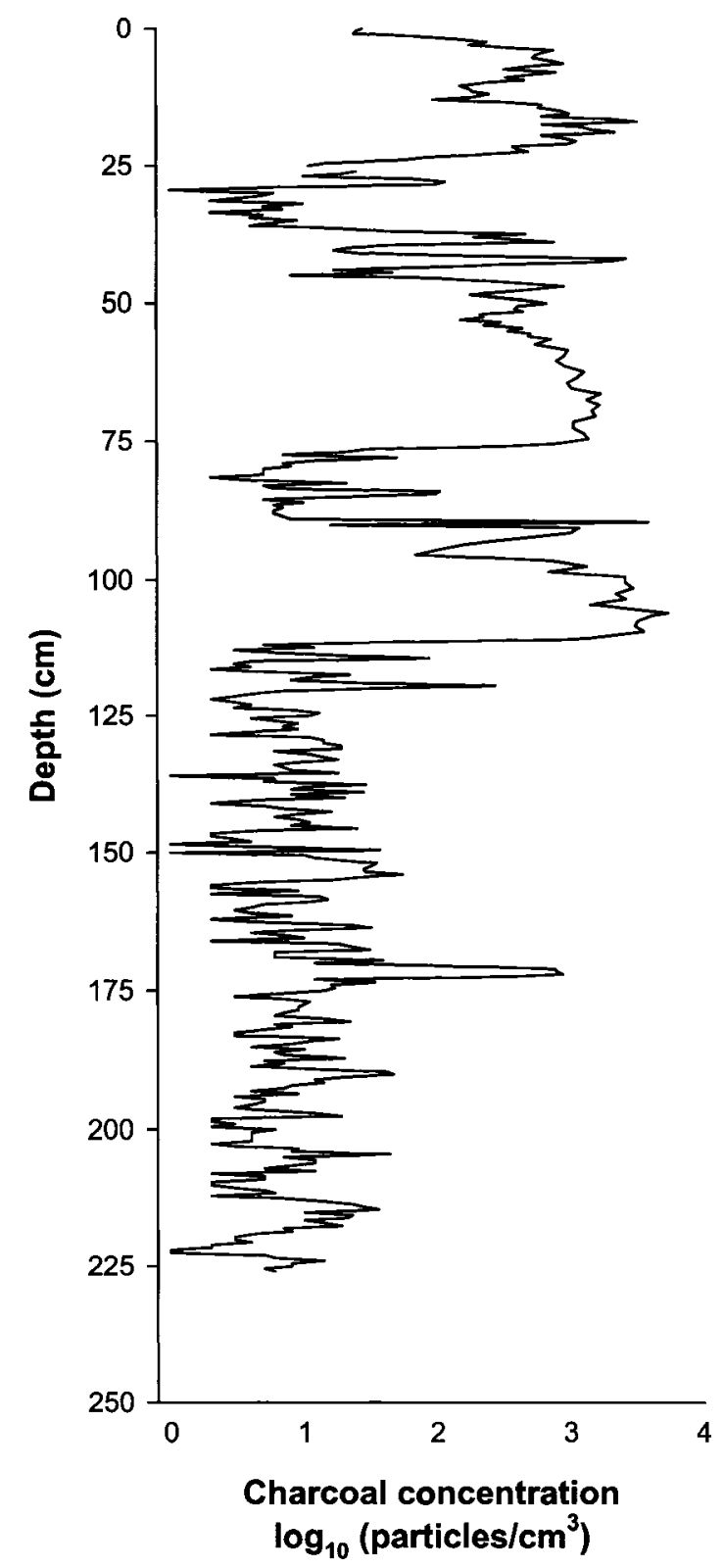

b)

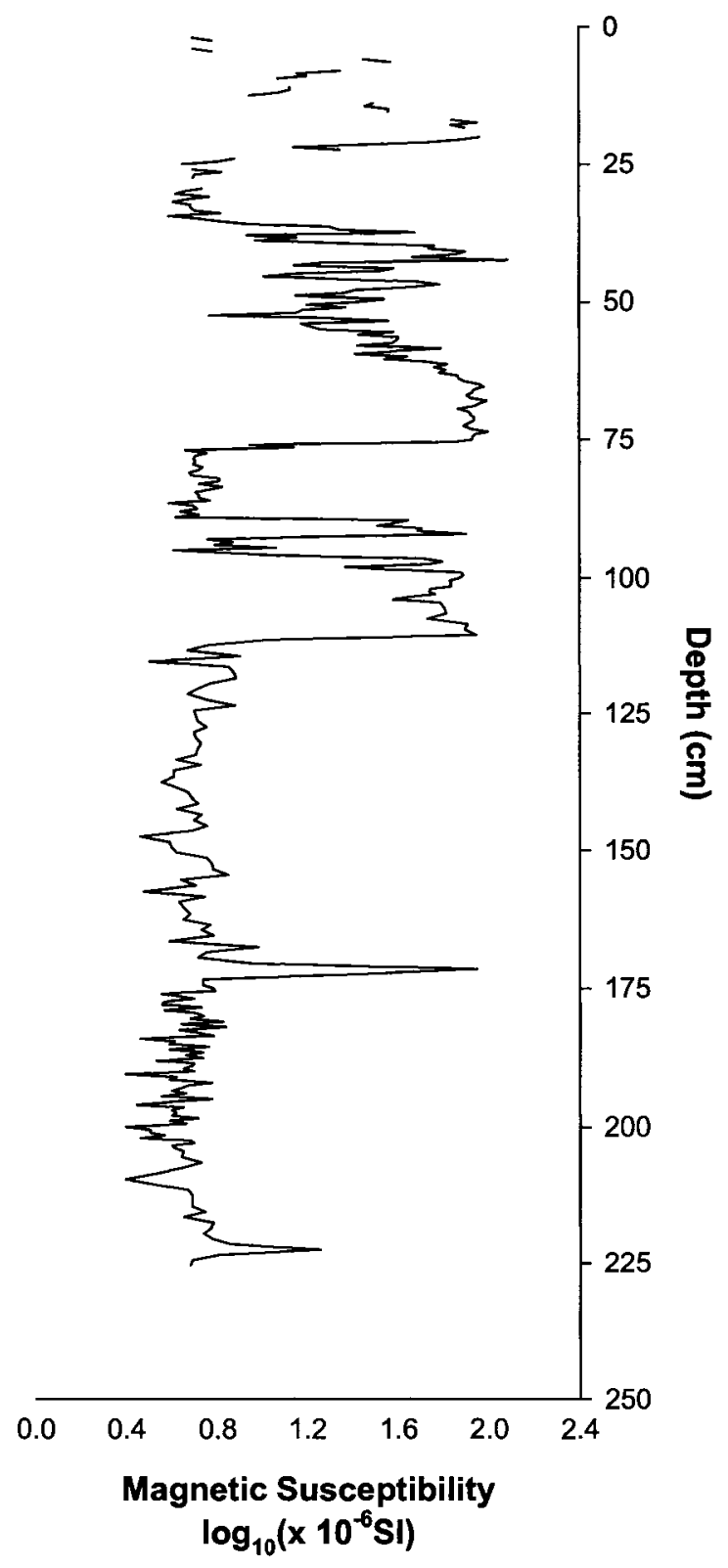

Figure 5.6: Plots showing a) log-transformed charcoal concentrations; and b) logtransformed magnetic susceptibility. 


\subsection{Identification of Fire Events}

Using the program CHARSTER, the CHAR record was decomposed and a background CHAR level was calculated using a window width of 45 years. The background level reflects the CHAR values with initially low values between 803 and 1600 A.D. followed by a period of high background CHAR between 1600 and 2000 A.D. (Fig 5.7a). Using a threshold value of $0.21 \log _{10}$ (particles $/ \mathrm{cm}^{2} / \mathrm{yr}$ ), 20 fire events were identified during the period of record, including the three known fire events in 1998 , 1958 and 1890 documented in historical and dendrochronological records (Fig 5.7b).

Visual inspection of the inferred fire frequency series suggests that fire frequency increased throughout the period of record (Fig. 5.7c). Fire frequency increased from 3.6 fires/500 yrs in $\sim 800$ A.D. to 8.0 fires/500 yrs at $\sim 1260$ A.D. Fire frequency generally stabilized between $\sim 1260$ and $\sim 1600$ A.D with a slight increase in fire frequency to 8.9 fires $/ 500$ yrs at $\sim 1600$ A.D. Following this period of general stabilization, fire frequency continued to increase to 12.6 fires/500 yrs at 2000 A.D. However, the beginning and end of the inferred fire frequency series should be interpreted with caution as a result of the asymmetry of the peak frequency window width in these portions of the series. 
a)

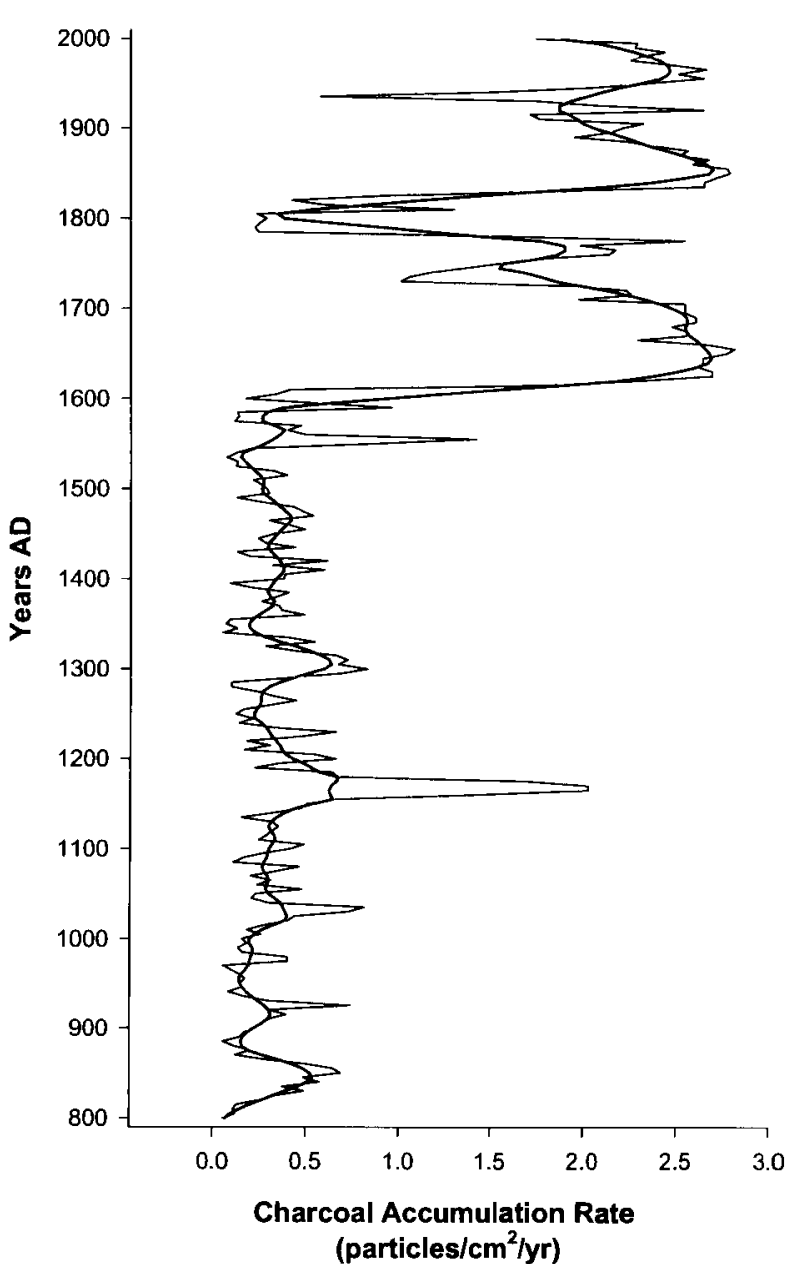

b)

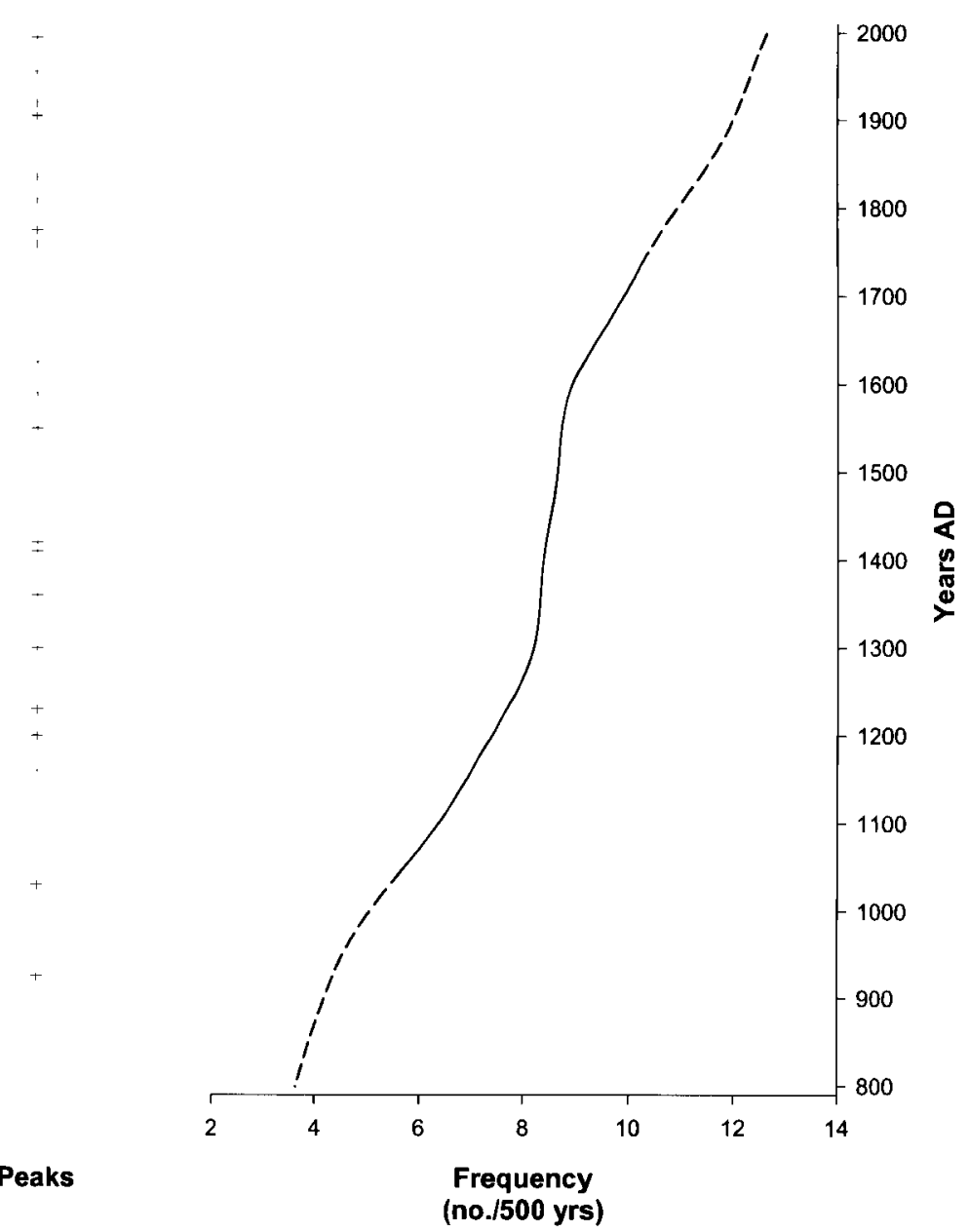

Figure 5.7: Plots showing a) log-transformed CHAR interpolated to 5-year even age interval and background CHAR level (red line); b) peak events representing fires $(+)$; and c) inferred fire frequency (dashed blue lines indicate periods where the peak frequency window is asymmetrical and should be interpreted with caution). 


\section{CHAPTER 6 \\ DISCUSSION}

\subsection{Macroscopic Charcoal as an Indicator of Forest Fire}

The sedimentary record from Burnt Bowl watershed provides insight into the sedimentary processes surrounding forest fire events and the use of macroscopic charcoal as a tool for resolving past fire history. Results of the analysis suggest that macroscopic charcoal is a reliable tool for identifying the occurrence of past forest fires in southcentral Yukon Territory. The magnetic susceptibility and LOI profiles from the sediment core are consistent with the charcoal record providing evidence supporting the use of macroscopic charcoal to identify fire activity in the watershed. The synchronous increase in charcoal concentration and magnetic susceptibility and decrease in organic and $\mathrm{CaCO}_{3}$ content may reflect fire-induced pedogenic processes occurring on the landscape.

Magnetic susceptibility has effectively been used to detect or confirm a fire signal in lake sediment records in past studies (Rummery et al., 1979; Long et al., 1998; Geydes et al., 2000; Hallett and Hills, 2006). During a fire event, weakly magnetic iron oxides and hydroxides are thermally transformed to ferrimagnetic magnetite or maghemite in the presence of burning organic matter (Le Borgne, 1960; Oldfield, 1991; Dearing et al., 1996; Geydes et al., 2000). Once transformed, these sediments are then transported to the lake basin through erosional processes on the landscape. In contrast, as a high severity fire burns through a watershed, organic material combusted leaving the mineral soil below. As a result, input of allochthonous inorganic material increases creating a proxy record of fire events within the watershed. Evidence for the combustion of the organic 
layer during recent fire events is present throughout the watershed in the form of exposed root collars that have been charred and the presence of the White River Ash at the surface at various locations around the watershed. (Fig 6.1)

The sediment core is primarily composed of organic gyttja with a number of coarse grained sediment layers which correspond to the increases in charcoal concentration and magnetic susceptibility. These coarse grained layers are interpreted to represent large fire events in the past of similar magnitude to the 1998 event. Only during these extreme events is the organic layer consumed by the fire leaving the mineral and thermally enhanced soils exposed. These highly magnetic sediments are then transported to the lake basin causing an increase in the magnetic susceptibility profile. As organic soils have been consumed, organic inputs to the lake decrease. The coarse grain sediments likely result from increased sediment transport to the lake as a result of the destabilization of the landscape due to the removal of vegetation and organic soils by fire as suggested by the high sedimentation rates in the top portion of the core between 0 and $46 \mathrm{~cm}$. These types of events likely explain the $0.5 \mathrm{~cm}$ thick layer of White River Ash deposited at $55 \mathrm{~cm}$. Removal of the organic matter and exposure of the mineral soil below, including the WRA, would allow re-activation of this material and subsequent deposition into the lake basin. Further, re-activation of terrestrial materials may also account for the anomalous ${ }^{14} \mathrm{C}$ dates. The increase in charcoal concentrations at these coarse grain intervals imply that forest fires play an integral role in the sedimentary processes in the watershed. Sedimentation rates in the lower portion of the core do not demonstrate an increase in sediment influx during fire events. However, this could be 


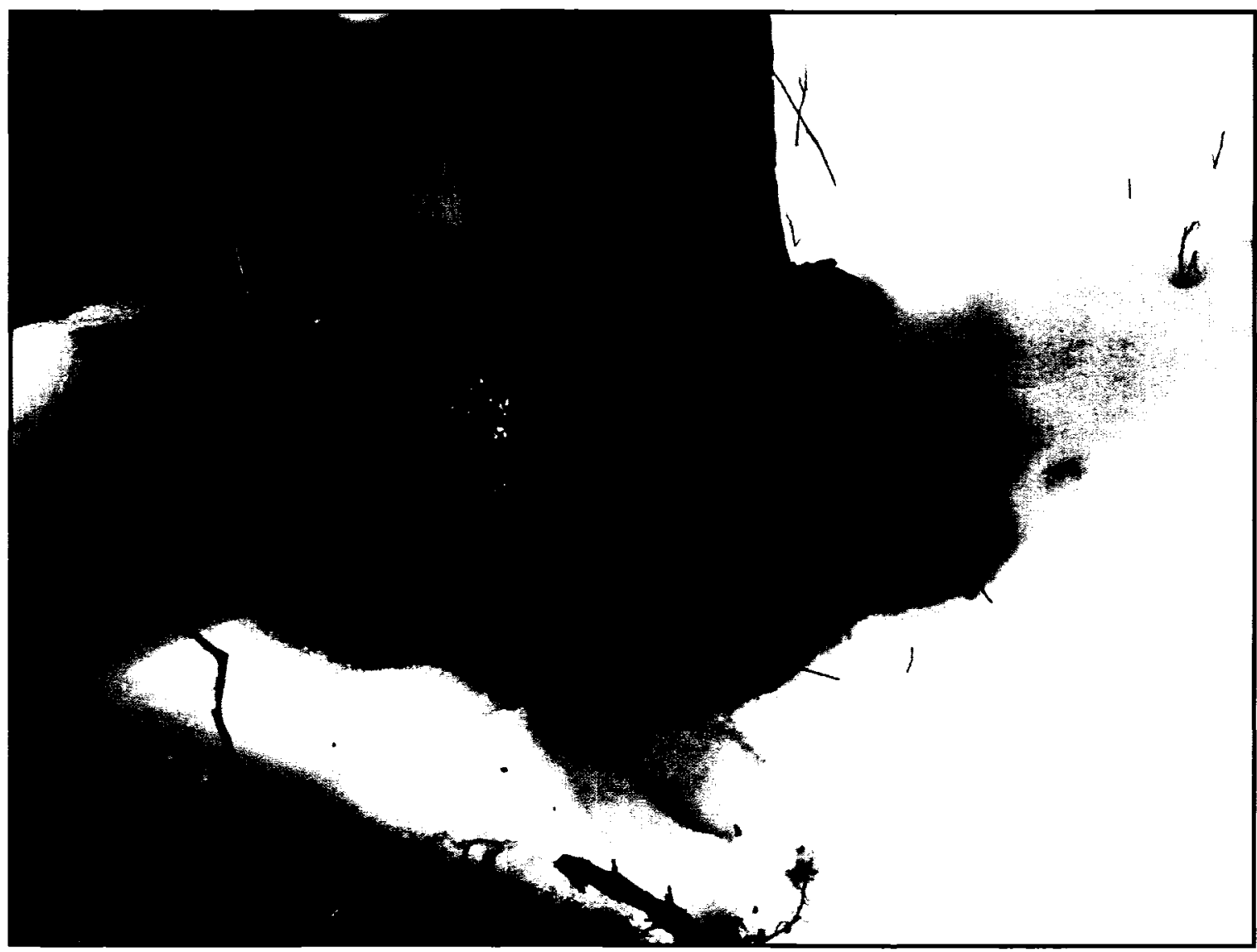

Figure 6.1: Photograph showing charred root collar indicating the removal of the organic layer as a result combustion by fire. 


\subsection{Fire History Record of South Central-Yukon Territory}

The macroscopic charcoal record from Burnt Bowl Lake provides a history of fire spanning the past 1200 years. The record captures known fire events determined by an analysis of stand-age structure and historically documented fires during the $20^{\text {th }}$ century. The record of past fire events is also consistent with previously published studies on climate and fire history in the southern Yukon Territory.

Two known fire events have occurred in the Burnt Bowl watershed during the $20^{\text {th }}$ century. Fires in 1958 and 1998 were identified in the sediment record as distinct peaks in CHAR in 1955 and 1995 in addition to 18 other peak events throughout the record. As the CHAR record was re-sampled to 5-year age intervals, the 1955 and $1995 \mathrm{CHAR}$ peaks include CHAR values from 1955 to 1960 and 1995 to 2000 respectively and thus likely represent these historical fires. The last complete growth ring on the majority of the trees sampled in the watershed correspond to the years 1996 or 1997 and likely represent the 1998 fire. The fact that the last complete growth ring is not 1998 in most cases is likely due to the fact that the fire occurred in the middle of the growing season or rings being removed from the trees by the fire. The CHAR record also identified a fire event at the beginning of the $20^{\text {th }}$ century at 1905 . This event is in general agreement with a pulse in recruitment around the lake between 1870 and 1890. This pulse in recruitment in the late 1800 s has also been noted elsewhere in the Fox Lake region. King (2006) identified a similar recruitment pulse beginning in 1870 and centered around 1890 at three sampling sites in close proximity to the watershed. Yalcin et al. (2006) also identified the 1860 s and 1880 s as periods of high fire in Yukon Territory with peak fire activity occurring in the 1890 s as indicated by residual concentrations of $\mathrm{NH}_{4}^{+}$in the 
Eclipse ice core. The lag in the CHAR record may represent slight dating inaccuracies. The Eclipse ice core record also identifies periods of high fire activity in the 1760's, 1780 's, 1840's and 1920's which correspond to fire events in the Burnt Bowl record at $1760,1775,1835$ and 1920, respectively. In addition, Yalcin et al. (2006) suggest that the period from 1240 to 1410 was also a period of increased fire activity which is consistent with the occurrence of three fire events in the Burnt Bowl watershed.

The inability of the stand-age structure analysis to resolve the 1958 fire likely reflects the sampling strategy as a younger cohort in the watershed was not sampled due to the small diameter of the stems and the assumption that these trees would not provide series long enough to enable cross-dating. We suggest however, that this cohort may represent post-fire regeneration following the 1958 fire. The 1920 fire event identified in the CHAR record was also not identified by the stand-age structure analysis. Tinner et al. (2006) documented the transport of millimeter to centimeter-sized charcoal particles to a distance of $5 \mathrm{~km}$ under high wind conditions reaching $23 \mathrm{~m} / \mathrm{s}$. Similarly, Pisaric (2002) documented the transport of charred needles, buds and cones over a distance of approximately $20 \mathrm{~km}$ under wind conditions reaching $14 \mathrm{~m} / \mathrm{s}$. It is possible therefore that charcoal particles were carried from a fire beyond the watershed as a result of high winds resulting in the peak in CHAR at 1920 in the Burnt Bowl record. However, a synchronous increase in magnetic susceptibility at 1920 suggests that this event occurred in the watershed and may have only burned a portion of the watershed beyond the tree ring sampling perimeter which covered an area of approximately 2 ha. 


\subsection{Vegetation, Climate and Fire in South-Central Yukon Territory}

Within Yukon Territory, little is known about the natural fire regime and its controlling factors. The current knowledge-base stems from a relatively short period of observation beginning in 1950 and thus may be insufficient for the development of effective management strategies and the projection of future fire activity in south-central Yukon Territory. In order to effectively manage and project future forest fire conditions, it is imperative that our understanding of the factors controlling natural fire regimes be improved.

Numerous studies have reconstructed records of forest fire activity and investigated the factors controlling fire during the Holocene period in western North America (Whitlock, 1993; Long et al., 1998; Hallett and Walker, 2000; Hallett et al., 2003; Lynch et al., 2003, 2004b; Hallett and Hills, 2006). Studies from the American northwest and southern British Columbia have concluded that climate, through variations in temperature and precipitation, is the main driver of forest fire regimes in these regions (Whitlock, 1993; Long et al., 1998; Hallett and Walker, 2000; Hallett et al., 2003; Hallett and Hills, 2006) while studies from Alaska suggest that fire regimes are controlled by shifts in vegetation composition as a result of changing climatic conditions (Lynch et al., $2003,2004 b)$. In order to investigate the controls on the fire regime in south-central Yukon Territory, previously published pollen records and paleoclimate records from southern Yukon Territory and Alaska are compared to the forest fire record from Burnt Bowl Lake. 


\subsubsection{Vegetation and Fire}

Perhaps the most striking and relevant feature of modern pollen assemblages from southern Yukon Territory is the increase in lodgepole pine pollen and synchronous decrease of black and white spruce. Lodgepole pine is regarded as a fire-maintained species. Lodgepole pine parklands are typified by frequent low-intensity surface fires unless there is a large accumulation of fuel on the surface which may lead to highintensity stand-replacing fire (Bourgeau-Chavez et al., 2000). Stand-replacement fires produce conditions that are highly favourable for the regeneration of lodgepole pine. Lodgepole pine has serotinous cones which open when heated to approximately $45-60^{\circ} \mathrm{C}$ (Lotan and Critchfield, 1990). Further, stand-replacing fires expose mineral soils that are best for seed germination of this species (Lotan and Critchfield, 1990; Bourgeau-Chavez et al., 2000). Lodgepole pine is a shade-intolerant species that germinates and grows rapidly. As a result, it often out-competes other species, colonizes and dominates recently burned areas (MacDonald, 1987).

Lodgepole pine pollen has been present at low percentages in pollen records in southern Yukon since ca. 9000 yrs B.P. (Wang and Geurts, 1991). Much higher values have only been recorded in pollen spectra since ca. 5000 yrs B.P. At Hail Lake in southeastern Yukon, lodgepole pine dominates the pollen spectra after 5000 yrs B.P. reaching values of $80 \%$ of the total pollen (Fig. 6.2a) (Cwynar and Spear, 1995). Similarly, lodgepole pine appears in the pollen record from Kettlehole Pond at ca. 4000 yrs B.P. and dominates the pollen spectra by ca. 2000 yrs B.P. with pollen percentage values ranging between 80 and 90\% (Fig 6.2b) (Cwynar, 1988; Cwynar and Spear, 1991). MacDonald and Cwynar (1985) suggest that lodgepole pine arrived at Kettlehole 

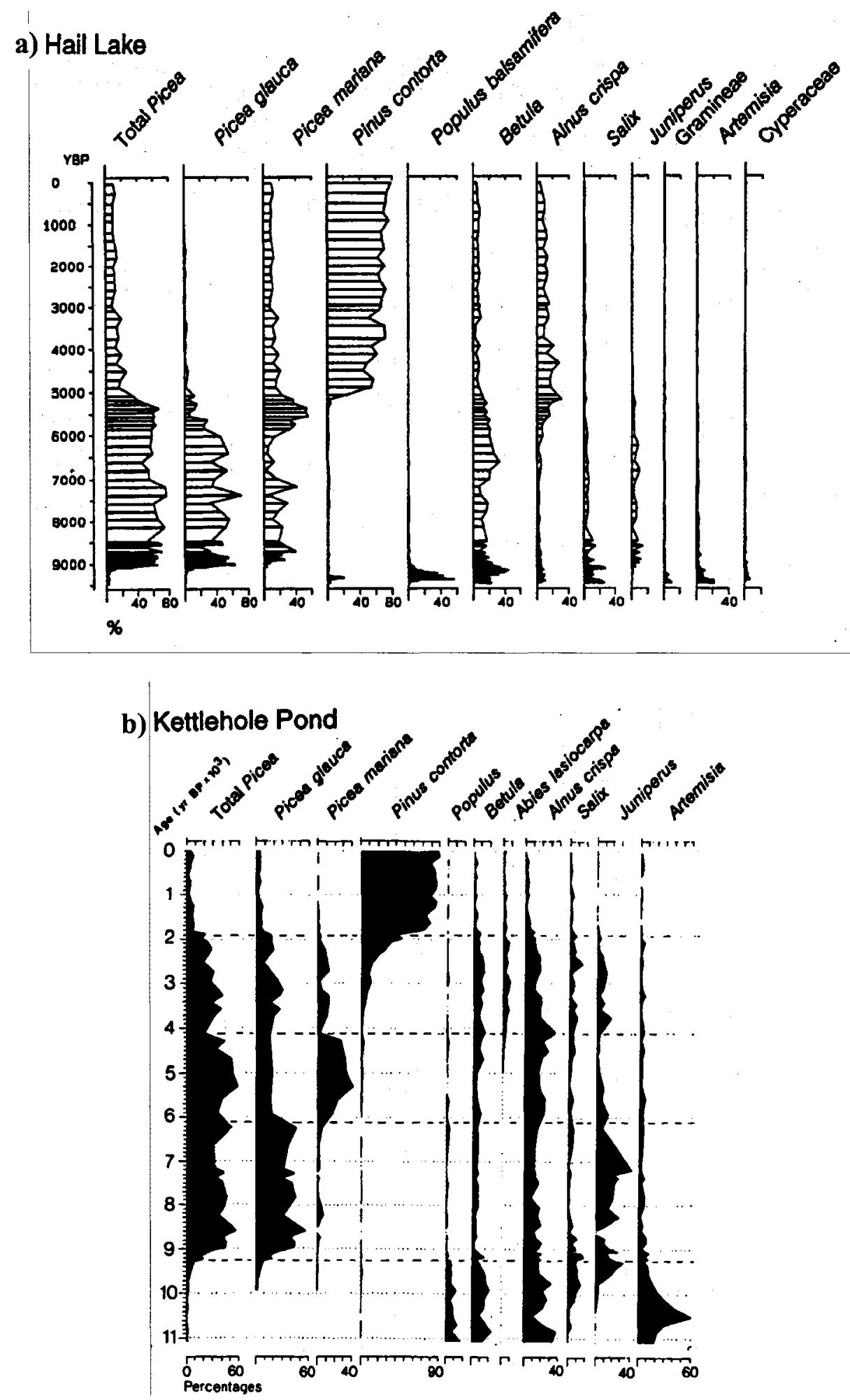

Figure 6.2: Pollen percentage diagrams from a) Hail Lake (Cwynar and Spear, 1995); and b) Kettlehole Pond (Cwynar, 1988). 
Pond $\left(60^{\circ} 04 \mathrm{~N}, 133^{\circ} 48^{\prime} \mathrm{W}\right)$ at 2490 yrs B.P. and at Cinquefoil-Dwindling Ponds $\left(61^{\circ}\right.$ $\left.05^{\prime} \mathrm{N}, 135^{\circ} 30^{\prime} \mathrm{W}\right)$ at ca. 1100 yrs B.P. Currently, lodgepole pine occurs from southeast to south-central Yukon Territory and in isolated patches extending northward towards Mayo and the intersection of the Klondike and Dempster Highways (Johnstone and Chapin, 2003). It is believed that lodgepole pine only reached its northern extent less than 400 years ago (MacDonald and Cwynar, 1985). However, recent research suggest that this species is expanding its ecological distribution northward through post-fire regeneration at the edge and interior of its current range (Johnstone and Chapin, 2003).

Based on the pollen assemblages (Fig. 6.2), it appears that the increase in fire frequency recorded in the Burnt Bowl sediment sequence is not related to the expansion of lodgepole pine as this species was established prior to the beginning of our record. Further, although lodgepole pine has been observed at sites to the south and within the burn perimeter north of Burnt Bowl Lake (Fig 6.3a); its presence has not been noted within the Burnt Bowl watershed. Although the majority of trees within the watershed are charred, the architecture of standing dead trees and wood characteristics of the crosssections suggest that white spruce is the dominant species within the watershed. Similarly, King (pers. comm., 2006) also noted the lack of lodgepole pine at sampling sites on the southwest side of the Klondike Highway adjacent to the Burnt Bowl watershed. Further, post-fire regeneration following the 1998 fire is dominated by white spruce as indicated by the presence of spruce seedlings within the watershed (Fig. 6.3b). The observational evidence suggests that the vegetation composition at Burnt Bowl Lake is similar to the post-glacial forests dominated by spruce prior to the expansion of lodgepole pine into southern Yukon as represented in the pollen records from the area 

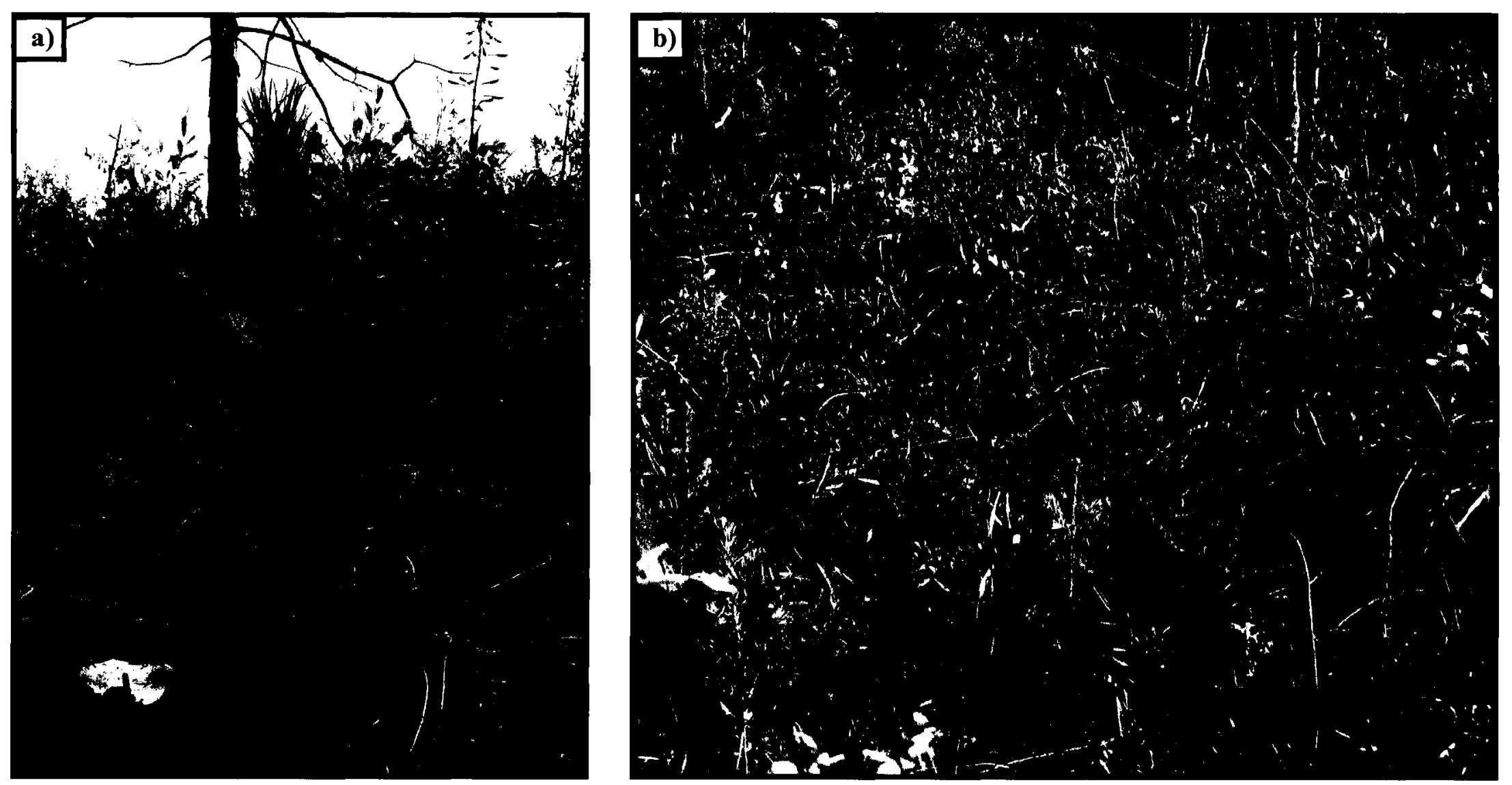

Figure 6.3: Photograph of a) lodgepole pine seedling at a site north of Burnt Bowl Lake. A charred mature lodgepole pine can be seen in the background; and b) several spruce seedlings growing at Burnt Bowl Lake. 
(Fig 6.2a and b).

\subsubsection{Climate and Fire}

Climatic conditions in the Yukon interior are influenced and moderated by air masses originating in the Gulf of Alaska, specifically the Aleutian Low pressure system (AL) (Bryson, 1966; Wahl et al., 1987; Anderson et al., 2005). The Gulf of Alaska is theprimary source for air flow in the Yukon (Wahl et al., 1987; Anderson et al., 2005). In July, air originating in the North Pacific dominates over southern and central Yukon Territory (Bryson, 1966). Comparison of the fire frequency record from Burnt Bowl Lake to recently published climate reconstructions from Yukon Territory and Alaska suggest a correspondence between fire activity and climate variability.

The fire frequency record from Burnt Bowl Lake indicates increasing fire frequency between ca. 800 and 1260 A.D. followed by a period of stable fire frequency between ca. 1260 and 1600 A.D. A final transition to increasing fire frequency occurs again between 1600 A.D. and the present. These trends are strikingly similar to the shifting phases of the AL during the past 1200 years. During periods of increasing fire frequency at Burnt Bowl Lake, Anderson et al.'s (2005) reconstruction of the AL suggest it was in a more eastward and intensified position (Fig. 6.4). An intensification of the AL delivers strong southerly winds into the mountain barrier along the Alaskan coast resulting in an enhanced rainshadow effect and thus drier conditions in the Yukon interior (Anderson et al., 2005). In contrast, when the AL is westward and/or weaker, the westerly trajectory of moisture and zonal flow patterns are able to move parallel to the coastal mountain barrier and infiltrate valleys trending southwest to northeast bringing 


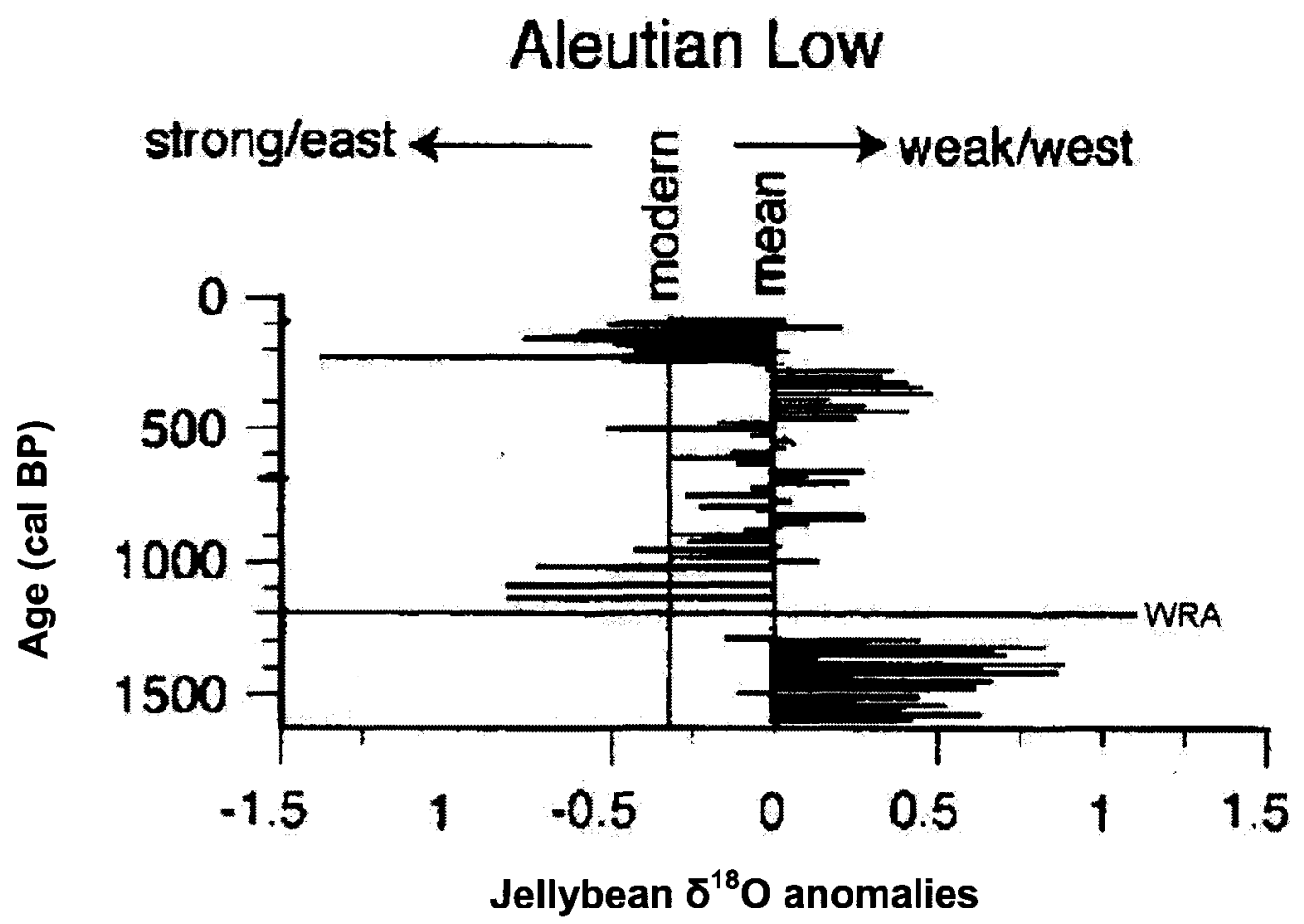

Figure 6.4: Reconstructed phases of the Aleutian Low pressure system based on $\delta^{18} \mathrm{O}$ from Jellybean Lake, YT (adapted from Anderson et al., 2005). 
more moisture to interior Yukon (Anderson et al., 2005). This coincides with a period of stabilization in the fire record between 1260 and 1600 A.D. A shift back to a strong and more easterly AL occurs at approximately 1700 A.D. which partially coincides with increasing fire frequency from 1600 A.D. to the present.

A comparison with a surface water temperature (SWT) reconstruction from Farewell Lake, Alaska provides further evidence that temperature influences fire frequency variability at Burnt Bowl Lake. The Farewell Lake SWT reconstruction indicates that temperatures were as warm or slightly cooler than present between 850 and 1200 A.D. (Fig. 6.5) (Hu et al., 2001). From 1200 to 1700 A.D., SWT was nearly $1.25^{\circ} \mathrm{C}$ cooler than present which coincides with a general stabilization in the fire frequency series. Following 1700 A.D., temperatures increased steadily to the present coinciding with highest fire frequencies in zone BB3 (Hu et al., 2001). These data show good agreement with our record, suggesting a strong linkage between fire frequencies and warming climates in south-central Yukon Territory.

The period of increasing fire frequency from 803 to ca. 1260 A.D corresponds to the Medieval Warm Period, a period of increased warmth generally cited as occurring between 1000 - 1300 A.D. (Crowley and Lowery, 2000; Broecker, 2001; Bradley et al., 2003). The stabilization of the fire frequency record is also concurrent with the onset of Little Ice Age conditions between ca. 1200 to 1850 A.D. (Luckman, 1986, 1995; Calkin et al., 2001). This period is characterized by extensive glacier expansion throughout Alaska and Yukon Territory (Denton and Karlén, 1977; Calkin et al., 2001). During this period, Calkin et al. (2001) noted two periods of glacial expansion along the Gulf of 


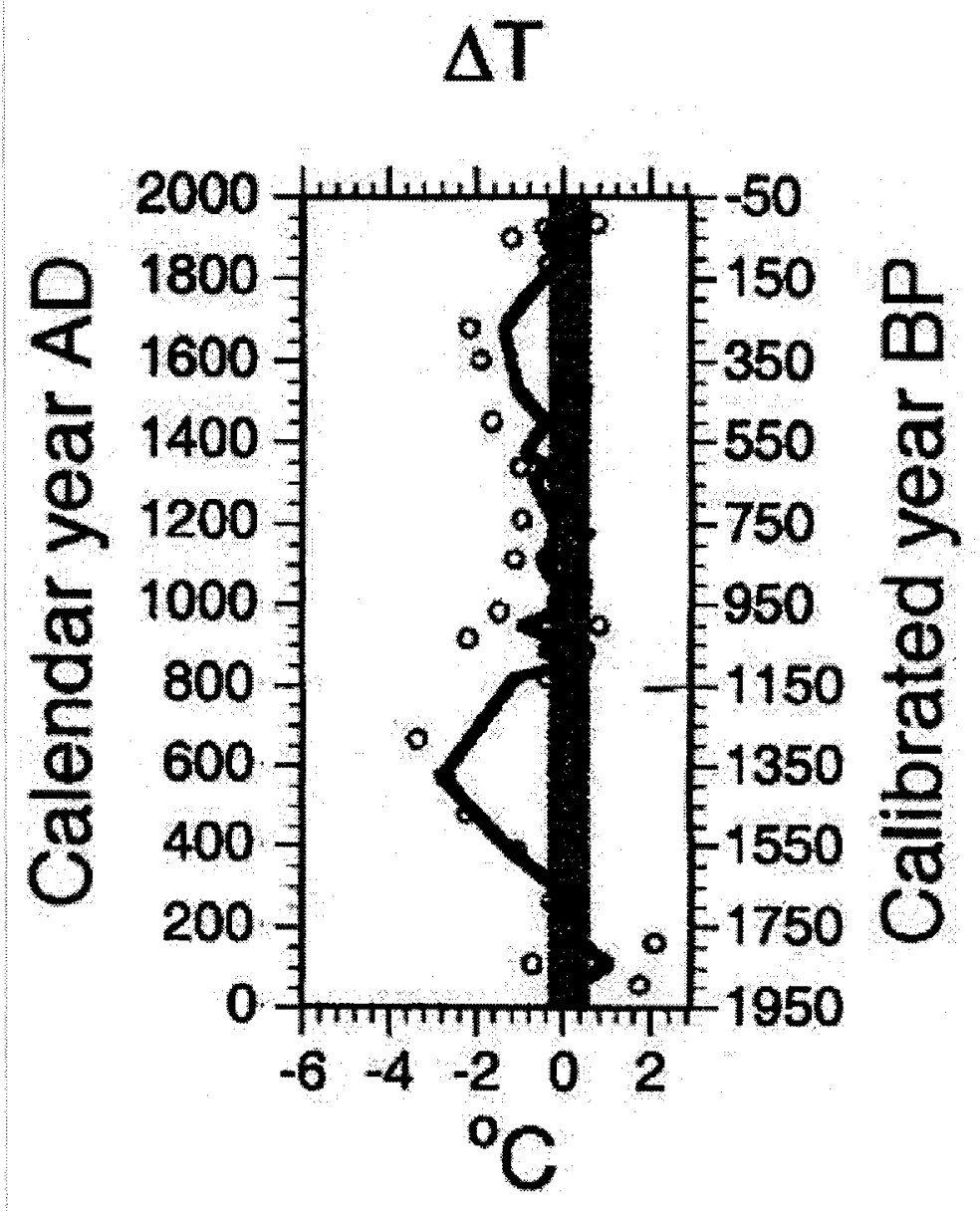

Figure 6.5: Reconstructed surface water temperature anomalies from Farewell Lake, Alaska (Hu et al., 2001). The vertical bar represents the temperature range of the $20^{\text {th }}$ century. 
Alaska at 1250 A.D. and 1650 A.D. In Yukon Territory, Denton and Stuiver (1966) noted that the Kaskawulsh and Donjek glaciers attained their maximum Holocene extents during the Little Ice Age. Similarly, the Rusty-Hazard glacier system in Yukon Territory also expanded and attained its Holocene maximum during this period (Denton and Karlén, 1977). These cooler conditions throughout northwestern North America appear to have stabilized forest fire disturbances in this part of Yukon Territory at that time. The record from Burnt Bowl Lake suggests only a slight increase in fire frequency from $\sim 8.0$ fires/500 yrs to $~ 8-9$ fires/500 years. Following the Little Ice Age, tree ring records and the Farewell Lake SWT reconstruction indicate increasing temperatures across northwestern Canada. Tree ring records from treeline sites in Northwest Territories, Yukon and Alaska show an amelioration in temperature following the LIA at the beginning of the 1700's (Jacoby and D'Arrigo, 1989; D'Arrigo and Jacoby, 1993). Similarly, tree ring records from Alaska indicate a period of warming beginning in the mid 1600's followed by a cooling in the 1700's and a general increase in temperature beginning in the 1800's to the present (D'Arrigo et al., 2005). This period of warming following the LIA is consistent with increasing fire frequency at Burnt Bowl Lake beginning in ca. 1600 A.D. suggesting that the onset of warmer temperature may have provided ideal conditions for increased fire activity.

Fire frequency following the termination of the LIA may have also been influenced by an increase in anthropogenic activity in the region. The fire event at ca. 1890 coincides with the onset of the Klondike Gold Rush in the late 1800 s. Small parties of prospectors began to arrive in Yukon during the 1870s. However, it is estimated that between $30000-35000$ people converged on the Klondike goldfields during the great 
stampede of 1897-98 (Parks Canada, 2007). Further, the construction of the Overland Trail in 1902, connecting Whitehorse to Dawson, may have also contributed to increased fire activity in the region. The original trail headed west from Whitehorse across the Takhini River and followed Klusha Creek and Little River to Braeburn providing access to the region around the study area (Yukon Heritage Resource Unit, 2006). Consequently, it is possible that the fire event identified at ca. 1920 resulted from human ignition when this "roadway" was predominantly travelled by truck or caterpillar tractor (Yukon Heritage Resource Unit, 2006.). Subsequent fires in 1958 and 1998 were ignited by campfires that were not properly extinguished resulting in large stand-replacing fires. As a result, the increase in fire frequency following the LIA certainly represents an anthropogenic influence in addition to changing climatic conditions. 


\section{CHAPTER 7 \\ CONCLUSION AND FUTURE CONSIDERATIONS}

\subsection{Conclusion}

The objectives of this research were: 1) to examine the potential of using macroscopic charcoal preserved in lake sediment to study the occurrence of fire in southcentral Yukon Territory; and 2) to examine the occurrence of forest fires in south-central Yukon Territory in order to determine how the natural variability of forest fire regimes has changed in response to climate during the Late Holocene. These objectives were achieved by developing a reconstruction of historical fire events within the Fox Lake region of Yukon Territory at both millennial and centennial time scales.

The results of the study indicate that the use of macroscopic charcoal preserved in lake sediment is an effective tool for studying the occurrence of forest fires in southcentral Yukon Territory. The CHAR record from Burnt Bowl Lake corresponds to historical, dendrochronological and ice core fire records from the area. The CHAR record identified the 1998 and 1958 fires documented in historical records, the fire event during the late 1800 s recorded in dendrochronological records as well as fires in 1920 , 1835, 1775 and 1760 identified in the Eclipse ice core record. In addition, 13 other fires were identified by the CHAR record. CHAR peaks also correspond to increases in the magnetic susceptibility profile and synchronous decreases in organic and $\mathrm{CaCO}_{3}$ content which further supports the fire history reconstruction and suggests that magnetic susceptibility and LOI may also be used as proxies for fire. 
The charcoal record indicates that fire frequency generally has been increasing in south-central Yukon Territory since the White River eruption in 1147 A.D. Fire frequency increased from ca. 800 to 1260 A.D., stabilized between ca. 1260 and 1600 A.D. and then continued to increase from 1600 A.D. to present. Comparison with published pollen records from southern Yukon Territory and climate reconstructions from Yukon and Alaska suggest that the primary driver of fire frequency in south-central Yukon Territory is climate. More specifically, periods of increasing fire frequency correspond to periods of low precipitation and increased temperature. Periods of low precipitation are associated with the eastward shift and intensification of the Aleutian Low pressure system which enhances the rainshadow effect in the Yukon interior. The results demonstrate increasing fire frequency during the Medieval Warm Period followed by a stabilization of fire frequency beginning with the onset of Little Ice Age cooling. A return to increasing fire frequency generally corresponds to the amelioration of climate following the termination of Little Ice Age conditions and the influence of anthropogenic ignitions associated with increasing human activity in the area beginning with the onset of the Klondike Gold Rush.

Fire history studies from Alaska indicate that fire activity increased as a result of a shift in vegetation composition associated with cool and moist conditions. Results from Burnt Bowl Lake show that increasing fire activity is not associated with a shift in vegetation composition as the major vegetation assemblages in south-central Yukon Territory were well established prior to the beginning of our charcoal record and have undergone little change with respect to species composition during the past 2000 years. 


\subsection{Future Recommendations}

During this coming century, human-induced changes in the climate system through increased atmospheric greenhouse gas concentrations may alter natural fire regimes through an increase in fire severity, frequency and length of the forest fire season (Stocks et al., 1998). Consequently, climate warming could have the greatest impact on forest fire activity in the northwestern boreal forests as they are thought to be among the most sensitive to future climate change. This study has shown that climate variability is the primary driver of forest fire regimes in south-central Yukon Territory during the past 1200 years. In order to further our understanding of the climate-fire relation, it is imperative that we develop long records of fire occurrences extending beyond the instrumental period of record.

This study provides a high resolution record of fire extending back to 1202 A.D. covering only a small portion of the Holocene period. In order to extend the fire record, it is recommended that macroscopic charcoal analysis, magnetic susceptibility and losson-ignition be carried out on the additional Livingston piston core, measuring $611 \mathrm{~cm}$, collected in March 2006 from Burnt Bowl Lake. It is expected that this core contains the entire Holocene record as glaciolacustrine clays were recovered at the bottom of the core indicating the end of the last glacial period. Further, in order to support the macroscopic charcoal record, it is suggested that tree ring samples from the young age-cohort, not sampled during initial collection, be collected and analyzed to obtain evidence for postfire regeneration following the 1958 Braeburn fire. In addition, although this study has provided evidence for climate as the primary driver of fire activity in the area, it is recommended that pollen analysis and diatom analysis be carried out on BB-06-LC2 in 
order to develop a vegetation and climate reconstruction from the watershed. This information will allow a direct interpretation of the interaction between fire, climate and vegetation in the watershed. 


\section{REFERENCES}

Anderson, L., Abbott, M.B., Finney, B.P. and Burns, S.P. 2005. Regional atmospheric circulation change in the North Pacific during the Holocene inferred from lacustrine carbonate oxygen isotopes, Yukon Territory, Canada. Quaternary Research 64: 21-35.

Appleby, P.G., Nolan, P.J., Gifford, D.W., Godfrey, M.J., Oldfield, F. and Battarbee, R.W. 1986. $210 \mathrm{~Pb}$ dating by low background gamma counting. Hydrobiologia 143: 21-27.

Arctic Climate Impact Assessment. 2004. Impacts of a Warming: Arctic Climate Impact Assessment Overview Report. New York: Cambridge University Press.

Atlas of Canada. 2006. Provincial and Territorial Outline Map: Yukon Territory With Names. Natural Resources Canada. [online]. (updated: January 16, 2007) Available from: http://atlas.nrcan.gc.ca/site/english/maps/reference/outlineprov terr

Barthelet, P., L. Terray, L., and Valcke, S. 1998. Transient $\mathrm{CO}_{2}$ experiments using the ARPEGE/OPAICE non-flux corrected coupled model. Geophysical Research Letters 25: 2277-2280.

Bergeron, Y., Gauthier, S., Kafka, V., Lefort, P., and Lesieur, D. 2001. Natural fire frequency for the eastern Canadian boreal forest: consequences for sustainable forestry. Canadian Journal of Forest Research 31: 384-391.

Bessie, W.C. and Johnson, E.A. 1995. The relative importance of fuels and weather on fire behaviour in subalpine forests. Ecology 76 (3): 747-762.

Boer, G.J., Flato, G., and Ramsden, D. 2000. A transient climate change simulation with greenhouse gas and aerosol forcing: projected climate for the 21 st century. Climate Dynamics 16: 427-450.

Bourgeau-Chavez, L.L., Alexander, M.E., Stocks, B.J. and Kasischke, E.S. 2000. Distribution of Forest Ecosystems and the Role of Fire in the North American Boreal Region. In E.S. Kasischke and B.J. Stocks, eds. Fire, Climate Change, and Carbon Cycling in the Boreal Forest. New York: Springer-Verlag, 2000, pp. $111-131$.

Bradley, R.S., Hughes, M.K., and Diaz, H.F. 2003. Climate in Medieval Time. Science 302 (5644): 403-304. 
Braeburn Lake. [computer map] 1:50 000. National Topographic Database 1:50 000 105E/5E. Sherbrooke, Quebec: Natural Resources Canada, 1961. Using: Arcview [GIS Software]. Version 3.2. Redlands, CA: Environmental Systems Research Institute, Inc., 1992-1999.

Broecker, W.S. 2001. Was The Medieval Warm Period Global. Science 291 (5508): 1497-1499.

Bryson, R.A. 1966. Air masses, streamlines and the boreal forest. Geographical Bulletin 8: 228-269.

Calkin, P.E., Wiles, G.C. and Barclay, D.J. 2001. Holocene coastal glaciation in Alaska. Quaternary Science Reviews 20: 449-461.Chapman, W.L. and Walsh, J.E. 2003. Observed climate change in the Arctic, updated from Chapman and Walsh, 1993: Recent variations of the sea ice and air temperatures in high latitudes. Bulletin of the American Meteorological Society 74 (1): 33-47.

Clague, J.J., Evans, S.G., Rampton, V.N. and Woodsworth, G.L. 1995. Improved age estimates for the White River and Bridge River tephras, Western Canada. Canadian Journal of Earth Science 32: 1172-1179.

Clark, J.S. 1990. Fire and climate change during the last $750 \mathrm{yr}$ in northwestern Minnesota. Ecological Monographs 60 (2): 135-159.

Clark, J.S., Lynch, J.A., Stocks, B.J., and Goldammer, J.G. 1998. Relationship between charcoal particles in air and sediment in west-central Siberia. The Holocene 8: 1929.

Clark, J.S., and Royale, P.D. 1996. Local and regional sediment charcoal evidence for fire regimes in pre-settlement northeastern North America. Journal of Ecology 84: $365-382$.

Cleveland, W.S. 1979. Robust Locally Weighted Regression and Smoothing Scatterplots. Journal of the American Statistical Association 74: 829-836.

Cropper, J.P. and Fritts, H.C. 1981 Tree-ring width chronologies from the North American Arctic. Arctic and Alpine Research 13 (3): 245-260.

Crowley, T.J. and Lowery, T.S. 2000. How warm was the Medieval Warm Period? Ambio 29 (1): 51-54. 
Cubasch, U., Meehl, G.A., Boer, G.J., Stouffer, R.J., Dix, M.., Noda, A., Senior, C.A., Raper, S. and Yap, K.S. 2001. Projections of Future Climate Change. In J.T. Houghton, Y. Ding, D.J. Griggs, M. Noguer, P.J. van der Linden, X. Dai, K. Maskell and C.A. Johnson, eds. Climate Change 2001: The Scientific Basis. Contribution of Working Group I to the Third Assessment Report of the Intergovernmental Panel on Climate Change. Cambridge: Cambridge University Press, 2001, pp. 527-582.

Cwynar, L.C. 1988. Late Quaternary vegetation history of Kettlehole Pond, southwestern Yukon. Canadian Journal of Forest Research 18: 1270-1279.

Cwynar, L.C. and Spear, R.W. 1991. Reversion of forest to tundra in the central Yukon. Ecology 72 (1): 202-212.

Cwynar, L.C. and Spear, R.W. 1995. Paleovegetation and paleoclimatic changes in the Yukon at 6 KA BP. Géographie Physique et Quaternaire 49 (1): 29-35.

D'Arrigo, R. and Jacoby, G.C. 1993. Secular trends in high northern latitude temperature reconstructions based on tree-rings. Climatic Change 25: 163-177.

D’Arrigo, R., Mashig, E., Frank, F., Wilson, R. and Jacoby, G. 2005. Temperature variability over the past millennium inferred from Northwestern Alaska tree rings. Climate Dynamics 24: 227-236.

Dearing, J.A., Hay, K.L., Baban, S.M.J., Huddleston, A.S., Wellington, E.M.H. and Loveland, P.J. 1996. Magnetic susceptibility of soil: an evaluation of conflicting theories using a national dataset. Geophysical Journal International 127: 728734.

Denton, G.H. and Karlén, W. 1977. Holocene glacial and tree-line variations in the White River Valley and Skolai Pass, Alaska and Yukon Territory. Quaternary Research 7: 63-111.

Denton, G.H. and Stuiver, M. 1966. Neoglacial chronology, northeastern St. Elias Mountains, Canada. American Journal of Science 264: 577-599.

DesRochers, A. and Gagnon, R. 1997. Is ring count at ground level a good estimate of black spruce age? Canadian Journal of Forest Research 27: 1263-1267.

Duk-Rodkin, A. 1999. Glacial limits map of Yukon. Geological Survey of Canada, Open File 3288, scale 1:250, 000 .

Environment Canada. 2004. Canadian Climate Normals 1971-2000: Braeburn, Yukon Territory. Meteorological Service of Canada Climate Data Online. [online]. (updated February 24, 2004) Available from: http://www.climate.weatheroffice.ec.gc.ca/climate normals/results e.html 
Flannigan, M.D., Logan, K.A., Amiro, B.D., Skinner, W.R. and Stocks, B.J. 2005. Future Area Burned in Canada. Climatic Change 72: 1-16.

Flannigan, M.D., Stocks, B.J., and Wotton, B.M. 2000. Climate change and forest fires. The Science of the Total Environment 262: 221-229.

Folland, C.K., Karl, T.R., Christy, J.R., Clarke, R.A., Gruza, G.V., Jouzel, J., Mann, M.E., Oerlemans, J., Salinger, M.J., and Wang, S.-W. 2001. Observed Climate Variability and Change. In J.T. Houghton, Y. Ding, D.J. Griggs, M. Noguer, P.J. van der Linden, X. Dai, K. Maskell and C.A. Johnson, eds. Climate Change 2001: The Scientific Basis. Contribution of Working Group I to the Third Assessment Report of the Intergovernmental Panel on Climate Change. Cambridge: Cambridge University Press, 2001, pp. 99-181.

Fritts, H.C. 1976. Tree-Rings and Climate. New York: Academic Press.

Froese, D. 2006. personal communication. Assistant Professor, Department of Earth and Atmospheric Sciences, University of Alberta.

Gardner, J., and Whitlock, C. 2001. Charcoal accumulation following a recent fire in the Cascade Range, northwestern USA, and its relevance for fire-history studies. The Holocene 11 (5): 541-549.

Gavin, D.G. 2006. CHARSTER 0.8.3 User's Guide, University of Vermont [online]. (updated June 22, 2006) Available from:

http://geography.uoregon.edu/gavin/software.html

Gavin, D.G., Hu, F.S., Lertzman, K. and Corbett, P. 2006. Weak climatic controls of stand-scale fire history during the late Holocene. Ecology 87 (7): 1722-1732.

Geydes, S.J., Jones, R.T., Tinner, W., Ammann, B., and Oldfield, F. 2000. The use of mineral magnetism in the reconstruction of fire history: a case study from Lago di Origlio, Swiss Alps. Palaeogeography, Palaeoclimatology, Palaeoecology 164: 101-110.

Glew, J. 1989. A new trigger mechanism for sediment samplers. Journal of Paleolimnology 2: 241-243

Glew, J.R., Smol, J.P. and Last, W.M. 2001. Sediment Core Collection and Extrusion. In W.M. Last and J.P. Smol, eds. Tracking Environmental Change Using Lake Sediments. Volume 1: Basin Analysis, Coring and Chronological Techniques. Dordrecht: Kluwer Academic Publishers, 2001, pp. 73-105. 
Hallett, D.J. and Hills, L.V. 2006. Holocene vegetation dynamics, fire history, lake level and climate change in the Kootenay Valley, southeastern British Columbia, Canada. Journal of Paleolimnology 35: 351-371.

Hallett, D.J., Lepofsky, D.S., Mathewes, R.W. and Lertzman, K.P. 2003. 11000 years of fire history and climate in the mountain hemlock rain forests of southwestern British Columbia based on sedimentary charcoal. Canadian Journal of Forest Research 33: 292-312

Hallett, D.J. and Walker, R. 2000. Paleoecology and its application to fire and vegetation management in Kootenay National Park, British Columbia. Journal of Paleolimnology 24 (4): 401-414.

Heinselman, M.L. 1973. Fire in the virgin forests of the boundary waters canoe area, Minnesota. Quaternary Research 3: 329-382.

Heiri, O., Lotter, A. and Lemcke, G. 2001. Loss on ignition as a method for estimating organic and carbonate content in sediments: reproducibility and comparability of results. Journal of Paleolimnology 25: 101-110.

Hély, C., Flannigan, M., Bergeron, Y. and McRae, D. 2001. Role of vegetation and weather on fire behavior in the Canadian mixedwood boreal forest using two fire behavior prediction systems. Canadian Journal of Forest Research 31: 430-441.

Heyerdahl, E.K., Brubaker, L.B. and Agee, J.K. 2001. Spatial controls of historical fire regimes: a multiscale example from the interior west: USA. Ecology 82 (3): 660678.

Holmes, R.L. 1983. Computer-assisted quality control in tree-ring dating and measurement. Tree-Ring Bulletin 43: 69-78.

Hu, F.S., Ito, E., Brown, T.A., Curry, B.B. and Engstrom, D.R., 2001 Pronounced climatic variations in Alaska during the last two millennia. Proceedings of the National Academy of Sciences 98 (19): 10552-10556.

Hulme, M. and Jones, P.D. 1994. Global climate change in the instrumental period. Environmental Pollution 83: 23-36.

Jackson, L.E. Jr., Duk-Rodkin, A. and Hughes, O.L. 1991. The last Cordilleran ice sheet in Yukon Territory. Géographie Physique et Quaternaire 45: 341-354.

Jacoby, G.C. and D'Arrigo, R.D. 1989. Reconstructed northern hemisphere annual temperature since 1671 based on high-latitude tree-ring data from North America. Climatic Change 14: 39-59. 
Johnson, E.A., and Gutsell, S.L. 1994. Fire frequency models, methods and interpretations. Advances in Ecological Research 25: 239-287.

Johnson, E.A. and Larsen, C.P.S. 1991. Climatically induced change in fire frequency in the southern Canadian Rockies. Ecology 72 (1): 194-201.

Johnstone, J. 2004. personal communication. Assistant Professor, Department of Biology, University of Saskatchewan.

Johnstone, J.F. and Chapin, S.F. 2003. Non-equilibrium succession dynamics indicate continued northern migration of lodgepole pine. Global Change Biology 9: 14011409.

Jones, P. D. and Briffa, K. 1992. Global surface air temperature variations: Part I the instrumental period. The Holocene 2: 174-88.

King, G.M. 2006. personal communication. Master of Science candidate, Department of Geography, Carleton University.

King G.M. 2006. Post-Fire Patterns of White Spruce Recruitment, Fox Lake, YT. B.Sc. Thesis. Carleton University.

Kipfmueller, K.F., and Baker, W.L. 1998. A comparison of three techniques to date stand-replacing fires in lodgepole pine forest. Forest Ecology and Management 104: 171-177.

Larsen, C.P.S. 1997. Spatial and temporal variations in boreal forest fire frequency in Northern Alberta. Journal of Biogeography 24 (5): 663-673.

Latif, M. and Barnett, T.P. 1996. Decadal variability over the North Pacific and North America: dynamics and predictability. Journal of Climate 9: 2407-2422.

Le Borgne, E. 1960. Influence du feu sur les propriétés magnétique du sol et sur celles du schiste et du granit. Annales Geophysicae 16: 159-195.

Long, C.J. and Whitlock, C. 2002. Fire and vegetation history from the Coastal rainforest of the Western Oregon Coast Range. Quaternary Research 85: 215-225.

Long, C.J., Whitlock, C, Bartlein, P.J, and Millspaugh, S.H. 1998. A 9000-year fire history from the Oregon Coast Range, based on a high-resolution charcoal study. Canadian Journal of Forest Research 28: 774-787.

Lotan, J.E. and Critchfield, W.B. 1990. Lodgepole pine. In R.M. Burns and B. H. Honkala, tech. coords. Silvics of North America: 1. Conifers, Agriculture Handbook 654. Washington, DC: U.S. Department of Agriculture, Forest Service, 1990, pp. 604-629. 
Luckman, B.H. 1986. Reconstruction of Little Ice Age events in the Canadian Rocky Mountains. Géographie Physique et Quaternaire 40: 17-28.

Luckman, B.H. 1995. Calendar-dated, early "Little Ice Age" glacier advance at Robson Glacier, British Columbia, Canada. The Holocene 5 (2): 149-159.

Lynch, J.A., Clark, J.S., Bigelow, N.H., Edwards, M.E. and Finney, B.P. 2003. Geographic and temporal variations in fire history in boreal ecosystems of Alaska. Journal of Geophysical Research 108 (D1): FFR8-1 - FFR 8-17.

Lynch, J.A., Clark, J.S., and Stocks, B.J. 2004a Charcoal production, dispersal, and deposition from the Fort Providence experimental fire: interpreting fire regimes from charcoal records in boreal forests. Canadian Journal of Forest Research 34: 1642-1656.

Lynch, J.A., Hollis, J.L. and Hu, F.S. 2004b. Climatic and landscape controls of the boreal forest fire regime: Holocene record from Alaska. Journal of Ecology 92 : 477-489.

MacDonald, G.M. 1987. Postglacial development of the subalpine-boreal transition forest of western Canada. Journal of Ecology 75: 303-320.

MacDonald, G.M. 2003. Biogeography, Introduction to Space, Time and Life. New York: John Wiley \& Sons, Inc.

MacDonald, G.M. and Cwynar, L.C. 1985. A fossil based reconstruction of the late Quaternary history of lodgepole pine (Pinus contorta ssp. latifolia) in the western interior of Canada. Canadian Journal of Forest Research 15: 1039-1044.

MacDonald, S.E., Peters, V., Purdy, B.G. and Dale, M. 2001. Natural regeneration of white spruce following natural disturbance in the western boreal forest: Project report 2001-13. Alberta: Sustainable Forest Management Network.

Mantua, N.J., Hare, S.R., Zhang, Y., Wallace, J.M. and Francis, R.C. 1997. A Pacific interdecadal climate oscillation with impacts on salmon production. Bulletin of the American Meteorological Society 78: 1069-1079.

McBride, J.R. 1983. Analysis of tree rings and fire scars to establish fire history. TreeRing Bulletin 43: 51-67.

McCoy, V.M. and Burn, C.R. 2005. Potential alteration by climate change of the forestfire Regime in the boreal forest of Central Yukon Territory. Arctic 58 (3): 276285. 
Meehl, G.A., Boer, G.J., Covey, C., Latif, M., and Stouffer, R.J. 2000. The Coupled Model Intercomparison Project (CMIP). Bulletin of the American Meteorological Society 81: 313-318.

Miller, A.J., Cayan, D.C., Barnett, T.P., Graham, N.E., Oberhuber, J.M. 1994. Interdecadal variability of the Pacific Ocean: model response to observed heat flux and wind stress anomalies. Climate Dynamics 9: 287-302.

Miller, C. and Urban, D.L. 2000. Connectivity of forest fuels and surface fire regimes. Landscape Ecology 15: 145-154.

Milne, D. 2005. personal communication. Fire Prevention Coordinator, Wildland Fire Management, Government of Yukon.

Millpaugh, S.H. and Whitlock, C. 1995. A 750-yr fire history based on lake sediment records in central Yellowstone National Park. The Holocene 5: 283-292.

Millspaugh, S.H., Whitlock, C. and Bartlein, P.J. 2000. Variations in fire frequency and climate over the past $17000 \mathrm{yr}$ in central Yellowstone National Park. Geology 28 (3), 211-214.

Mohr, J.A., Whitlock, C. and Skinner, C.J. 2000. Postglacial vegetation and fire history, eastern Klamath Mountains, California. The Holocene 10: 587-601.

National Air Photo Library. A22197, photo 100 [aerial photograph]. 1:15 000. Ottawa, Ontario: Natural Resources Canada, 1970.

Natural Resources Canada. 2005. The State of Canada's Forests 2004-2005: The Boreal Forest. Ottawa: Canadian Forestry Service.

Oldfield, F. 1991. Environmental magnetism-a personal perspective. Quaternary Science Reviews 10: 73-85.

Parks Canada. 2007. Dredge No.4 National Historic Site of Canada. Parks Canada. [online]. (updated: January 2, 2007) Available from: http://www.pc.gc.ca/lhnnhs/yt/dn4/natcul/natcul3_E.asp\#rush

Pellow, S.M. 2006. Holocene Fire History of the Southeast Yukon Territory. M.Sc. Thesis. Carleton University.

Pisaric, M.F.J. 2002. Long distance transport of terrestrial plant material by convection resulting from forest fire. Journal of Paleolimnology 28: 349-354.

Profir, A.P. 2004. A Summer Energy Balance for Mayo Lake, Yukon Territory. B.A. Thesis. Carleton University. 
Purdy, B.G., MacDonald, S.E. and Dale, M.R.T. 2002. The regeneration niche of white spruce following fire in the mixedwood boreal forest. Silva Fennica 36, 289-306.

Reed, W.J. 2006. A note on fire frequency concepts and definitions. Canadian Journal of Forest Research 36 (7): 1884-1888.

Robbins, J.A. 1978. Geochemical and geophysical applications of radioactive lead isotopes. In J.P. Nriago, ed. Biogeochemistry of Lead. Amsterdam: North Holland, 1978, pp. 285-393.

Rollins, M.D., Morgan, P. and Swetnam, T. 2002. Landscape-scale controls over $20^{\text {th }}$ century fire occurrence in two large Rocky Mountain(USA) wilderness areas Landscape Ecology 17: 539-557.

Rummery, T.A., Bloemendal, J., Dearing, J., Oldfield, F. and Thompson, R. 1979. The persistence of fire-induced magnetic oxides in soils and lake sediments. Annales Geophysicae 35: 103-107.

Sandgren, P. and Snowball, I. 2001. Application of Mineral Magnetic Techniques to Paleolimnology. In W.M. Last and J.P. Smol, eds. Tracking Environmental Change Using Lake Sediments. Volume 2:Physical and Geochemical Methods. Dordrecht: Kluwer Academic Publishers, 2001, pp. 217-237.

Smith, S. 2004. Introduction. In C.A.S. Smith, J.C. Meikle and C.F. Roots, eds. Ecoregions of the Yukon Territory: Biophysical properties of Yukon Landscapes. PARC Technical Bulletin No. 04-01. British Columbia: Agriculture and Agrifoods Canada, 2004, pp. 3-4.

Spooner, I.S., Barnes, S., Baltzer, K.B., Raeside, R., Osborn, G.D. and Mazzuchi, D. 2003. The impact of air mass circulation dynamics on Late Holocene paleoclimate in northwestern North America. Quaternary International 108: 77 83.

Stephens, S.L. 1998. Evaluation of the effects of silviculture and fuels treatments on potential fire behaviour in Sierra Nevada mixed-conifer forests. Forest Ecology and Management 105: 21-35.

Stocks, B.J., Fosberg, M.A., Lynham, T.J., Mearns, L., Wotton, B.M., Yang, Q., Jin, J.Z., Lawrence, K., Hartley, G.R., Mason, J.A. and McKenney, D.W. 1998. Climate change and forest fire potential in Russian and Canadian boreal forests. Climatic Change 38 (1): 1-13.

Stocks, B.J, Mason, J.A., Todd, J.B. Bosch, E.M., Wotton, B.M., Amiro, B.D., Flannigan, M.D., Hirsch, K.G., Logan, K.A., Martell, D.L., and Skinner, W.R. 2003. Large forest fires in Canada, 1959-1997. Journal of Geophysical Research 108 (D1): FFR5-1 - FFR5-12. 
Stokes, M.A., and Smiley, T.L. 1968. An Introduction to Tree-Ring Dating. Chicago: The University of Chicago Press.

Stouffer, R.J. and S. Manabe, S. 1999. Response of a coupled ocean-atmosphere model to increasing atmospheric carbon dioxide: sensitivity to the rate of increase. Journal of Climate and Applied Meteorology 12: 2224-2237.

Tinner, W. Hofstetter, S., Zeugin, F., Conedera, M., Wohlgemuth, T. Zimmermann, L. and Zweifel, R. 2006. Long-distance transport of macroscopic charcoal by an intensive crown fire in the Swiss Alps - implications for fire history reconstruction. The Holocene 16 (2): 287-292.

Wahl, H.E. 2004. Yukon overview: Climate. In C.A.S. Smith, J.C. Meikle and C.F. Roots, eds. Ecoregions of the Yukon Territory: Biophysical properties of Yukon Landscapes. PARC Technical Bulletin No. 04-01. British Columbia: Agriculture and Agri-foods Canada, 2004, pp. 19-23.

Wahl, H.E., Fraser, D.B., Harvey, R.C. and Maxwell, J.B. 1987. Climate of Yukon. Ottawa: Environment Canada.

Wang, X.-C. and Geurts M.-A. 1991. Late Quaternary pollen records and vegetation history of the southwest Yukon Territory: a review. Géographie Physique et Quaternaire 45 (2): 175-193.

Whitlock, C. 1993. Postglacial vegetation and climate of Grand Teton and southern Yellowstone National Park. Ecological Monographs 63: 173-198.

Whitlock, C. 2001. Variations in Holocene fire frequency: a view from the Western United States. Biology and Environment 101B (1-2): 65-77.

Whitlock, C and Anderson, R.S. 2003. Fire History Reconstructions Based on Sediment Records from Lakes and Wetlands. In T.T. Veblen, W.L. Baker, G. Montenegro and T.W. Swetnam, eds. Fire and Climatic Change in Temperate Ecosystems of the Western Americas. New York: Springer, 2003, pp. 3-32.

Whitlock, C. and Larsen, C. 2001. Charcoal as a Fire Proxy. In J.P. Smol, H.J.B. Birks, and W.M. Last, eds. Tracking Environmental Change Using Lake Sediments. Volume 3: Terrestrial, Algal, and Siliceous Indicators. Dordrecht: Kluwer Academic Publishers, 2001, pp. 75-97.

Whitlock, C. and Millspaugh, S.H. 1996. Testing assumptions of fire history studies: an examination of modern charcoal accumulation in Yellowstone National Park. The Holocene 6: 7-15. 
Whitlock, C., Shafer, S.L. and Marlon, J. 2003. The role of climate and vegetation in shaping past and future fire regimes in the northwestern US and the implications for ecosystem management. Forest Ecology and Management 178: 5-21.

Wright, W.A., Mann, D.H. and Glaser, P.H. 1984. Piston corers for peat and lake sediments. Ecology 65: 657-659.

Yalcin, K., Wake, C.P., Kreutz, K.J. and Whitlow, S.I. 2006. A 1000-yr record of forest fire activity from Eclipse Icefield, Yukon, Canada. The Holocene 16 (2): 200209.

Yukon Ecoregions Working Group. 2004. Boreal Cordillera Ecozone. In C.A.S. Smith, J.C. Meikle and C.F. Roots, eds. Ecoregions of the Yukon Territory: Biophysical properties of Yukon Landscapes. PARC Technical Bulletin No. 04-01. British Columbia: Agriculture and Agri-foods Canada, 2004, pp. 157-158.

Yukon Heritage Resource Unit. 2006. The Overland Trail Whitehorse-Dawson City. Yukon Depatment of Tourism and Culture. [online]. (updated: November 14, 2006) Available from: http://www.yukonheritage.com/publications-overland.htm

Yukon Wildland Fire Management. 2005. 2004 Wildland Fire Review: Final Report. Whitehorse: Yukon Wildland Fire Management.

Zackrisson, 0. 1977. Influence of forest fires on the North Swedish boreal forest. Oikos 29: $22-32$. 